AL.2.2004- 42

c. $\partial$

Classification of the Sandhill and Sand Plain Plant Communities of the Wainwright Dunes Ecological Reserve

Prepared For:

Resource Data Branch Alberta Sustainable Resource Development Edmonton, Alberta

Prepared By:

Geowest Environmental Consultants Ltd.

December 2003
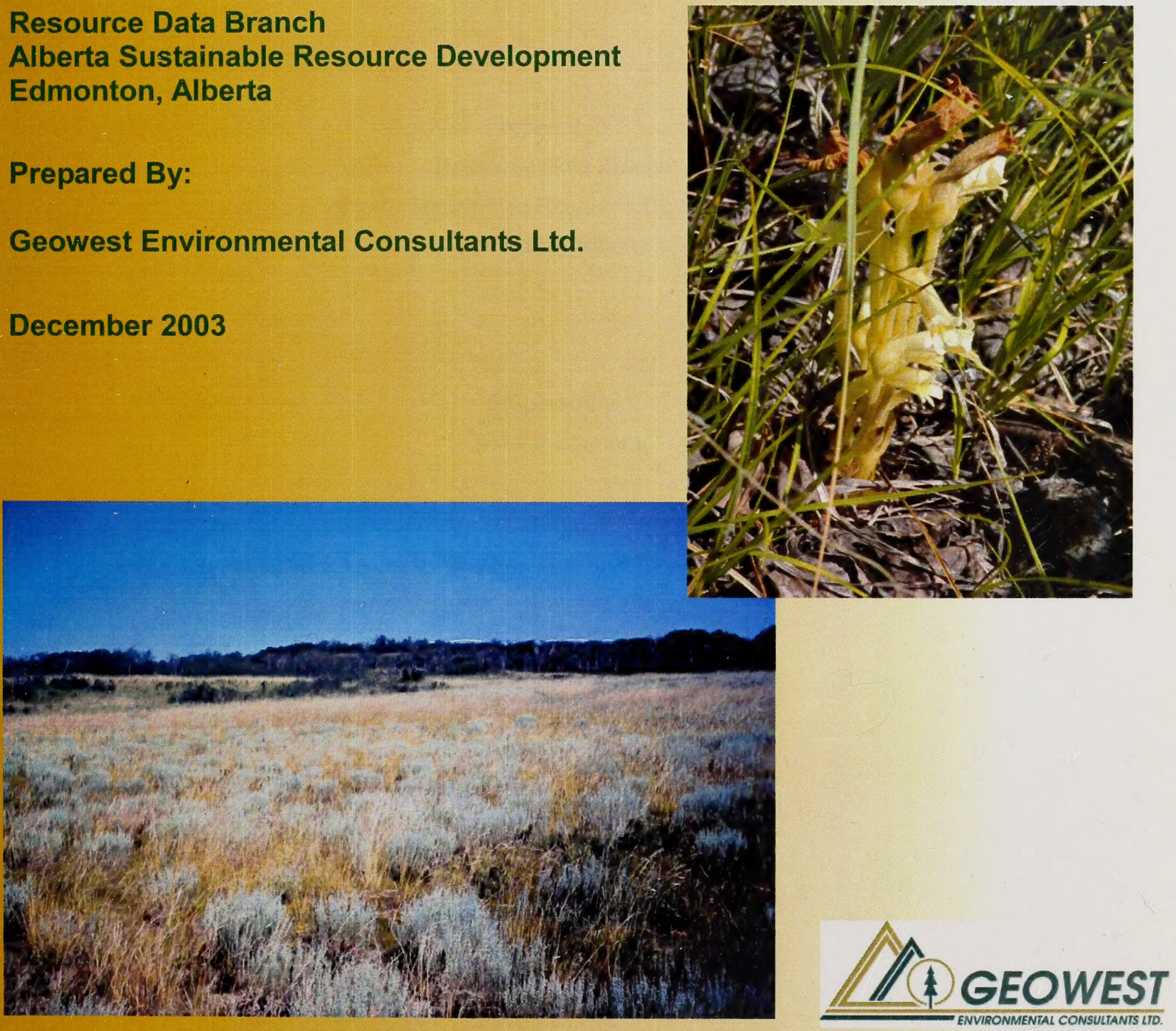



\title{
Classification of Sand Dune and Sand Plain Plant Communities in the Wainwright Dunes Ecological Reserve
}

\author{
Prepared for: \\ Resource Data Branch \\ Alberta Sustainable Resource Development \\ Edmonton, Alberta \\ Prepared by: \\ Valerie Coenen \\ Geowest Environmental Consultants Ltd. \\ Suite 203, 4208 - 97 Street \\ Edmonton, Alberta \\ Canada \\ T6E $5 Z 9$
}

December 2003 
Digitized by the Internet Archive in 2016 


\section{Executive Summary}

The Resource Data Division of Alberta Sustainable Resource Development contracted Geowest Environmental Consultants Ltd. to produce a classification of sand dune and sand plain plant community types within the Wainwright Dunes Ecological Reserve, an area found in the Parkland Natural Region of Alberta. This initiative is in support of the Alberta Natural Heritage Information Centre (ANHIC). ANHIC collects, evaluates and makes available data on elements of natural biodiversity in Alberta, including flora, fauna and native plant communities. ANHIC develops tracking lists of elements that are considered of high priority because they are considered rare or special in some way. ANHIC's long-term goal is to develop a list of plant community types that occur throughout the province and to attempt to identify community types that require conservation initiatives.

The Wainwright Dunes Ecological Reserve is located directly south of Canadian Forces Base (CFB) Wainwright, comprising an area of just over 2,800 hectares. The Wainwright Dunes Ecological Reserve is provincial Crown land, administered by Alberta Community Development. Current land uses consist primarily of cattle grazing on native pasture. The Buffalo Park Grazing Association holds the lease for grazing rights within and adjacent to the Ecological Reserve.

The objectives of this project are:

$>$ to develop a plant community classification of sand dune and sand plain plant communities of the Wainwright Dunes Ecological Reserve, representative of the Central Parkland Natural Subregion based on field survey, correlations with other surveys and any available previously-collected data

$>$ evaluate and assign a preliminary provincial conservation rank to each identified community type, based on its rarity/endemism or threats to its condition.

This was accomplished by developing a sampling protocol and subsequently collecting field data on plant communities of the sand dune and sand plain landscapes of the Wainwright Dunes Ecological Reserve. Furthermore, a comparison of defined plant community types to similar types described in previously conducted field surveys in similar landscapes in Alberta and adjacent provinces and states was completed. A similarity rating based on a scale provided by Corns (1983) is also provided.

This classification will provide a better understanding of plant community biodiversity in Alberta and will contribute to the development of a Canadian National Vegetation Classification (CNVC), the Canadian component of the International Classification of Ecological Communities (ICEC). The ICEC system has been adopted by the United States and it is a national standard for vegetation classification known as the U.S. National Vegetation Classification (USNVC).

An extensive literature search was completed, to locate references relating to aspen parkland sand dune and sand plain plant communities. Literature from other jurisdictions was also obtained, primarily for Saskatchewan, Manitoba, Montana, Idaho, Wyoming, North and South Dakota, Nebraska and Minnesota.

Field sampling occurred between July $14^{\text {th }}$ and August $1^{\text {st }}, 2002$ following a review of the sampling strategy with Alberta Sustainable Resource Development staff. In total 40 sampling plots were established, distributed throughout a range of community types and 
topographic positions. Survey sites were selected based on an initial review of the survey area, using aerial photographs and vegetation trends observed in the field.

Cluster and ordination analyses were performed on the field data resulting in 12 community types based on the hierarchical guidelines documented in the International Classification of Ecological Communities: Terrestrial Vegetation of the United States: Volume 1 - The National Classification System: Development, Status and Application (Grossman et al. 1998). Table I documents the names of the community types identified.

Table I. Sand dune and sand plain plant communities in the Wainwright Dunes Ecological Reserve.

\begin{tabular}{|l|c|}
\hline \multicolumn{1}{|c|}{ Community Type Name } & Preliminary Conservation Ranking \\
\hline $\begin{array}{l}\text { Betula occidentalis / Arctostaphylos uva-ursi - Juniperus horizontalis } \\
\text { Water birch / common bearberry - creeping juniper }\end{array}$ & S2S3 \\
\hline $\begin{array}{l}\text { Calamovilfa longifolia - Sporobolus cryptandrus - Carex siccata } \\
\text { Sand grass - sand dropseed - hay sedge }\end{array}$ & S2? \\
\hline $\begin{array}{l}\text { Elaeagnus commutata - Prunus virginiana / Carex siccata - Koeleria macrantha } \\
\text { Silverberry - chokecherry / hay sedge - june grass }\end{array}$ & S3S4 \\
\hline $\begin{array}{l}\text { Juniperus horizontalis / Stipa comata - Carex siccata } \\
\text { Creeping juniper / needle-and-thread - hay sedge }\end{array}$ & $\mathbf{S 3 ?}$ \\
\hline $\begin{array}{l}\text { Juniperus horizontalis / Calamovilfa longifolia - Carex pensylvanica ssp. heliophila } \\
\text { Creeping juniper / sand grass - sun-loving sedge }\end{array}$ & $\mathbf{S 5}$ \\
\hline $\begin{array}{l}\text { Populus balsamifera / Corylus cornuta - Cornus stolonifera / Aralia nudicaulis } \\
\text { Balsam poplar / beaked hazelnut - red-osier dogwood / wild sarsaparilla }\end{array}$ & $\mathbf{S 2 S 3}$ \\
\hline $\begin{array}{l}\text { Populus tremuloides / Juniperus horizontalis / Carex siccata } \\
\text { Aspen / creeping juniper / hay sedge }\end{array}$ & $\mathbf{S 3}$ \\
\hline $\begin{array}{l}\text { Populus tremuloides / Prunus virginiana - Amelanchier alnifolia / Carex siccata } \\
\text { Aspen / chokecherry - saskatoon / hay sedge }\end{array}$ & S5 \\
\hline $\begin{array}{l}\text { Populus tremuloides / Amelanchier alnifolia - Rosa acicularis / Poa palustris } \\
\text { Aspen / saskatoon - prickly rose / fowl bluegrass }\end{array}$ & SU \\
\hline $\begin{array}{l}\text { Salix bebbiana / Festuca saximontana } \\
\text { Beaked willow / Rocky Mountain sedge }\end{array}$ & SU \\
\hline $\begin{array}{l}\text { Salix petiolaris / Calamagrostis canadensis } \\
\text { Basket willow / bluejoint }\end{array}$ & \\
\hline $\begin{array}{l}\text { Stipa comata - Artemisia frigida - Selaginella densa } \\
\text { Needle-and-thread - pasture sagewort - prairie selaginella }\end{array}$ & S3S4 \\
\hline
\end{tabular}

Each community type identified from the analysis of the plot data was compared against floristically similar community types described for Alberta and other jurisdictions. A summary of the findings are provided as correlation tables, which compare the Wainwright Dunes community types against community types described in literature based on Alberta and other jurisdictions, respectively. A similarity rating between the community types, based on Corns (1983) and recently applied by Strong (2002), was also provided in the tables. A discussion of the community types and associated literature was also provided.

All proposed community types were assigned a preliminary provincial ranking and knowledge gaps were identified. The information in this report can be used to update the community-tracking list by including new community types. Finally, this report can also be used to decide which community types require further studies and to prioritize these studies. 


\section{Acknowledgements}

We wish to thank Keith Ainsley (Resource Data Division - Alberta Sustainable Resource Development), and Lorna Allen and Ksenija Vujnovic (Alberta Natural Heritage Information Centre - Alberta Community Development) for assistance throughout this project. Harry Loonen and Patrick J. Porter of Alberta Sustainable Resource Development in Wainwright were also valuable information sources on the Wainwright Dunes Ecological Reserve and provided many important references. The services of Kathy Tannas are also greatly appreciated for identification and verification of plant species. We are also grateful to Ruth Bonneville, Natalie Tashe and Dennis O'Leary for assistance with fieldwork, as well as Terry Lang (Geowest Environmental Consultants Ltd.) who contributed to the successful completion of this project. 


\section{Table of Contents}

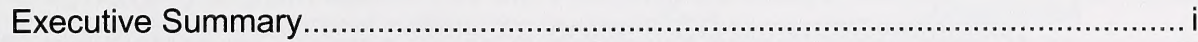

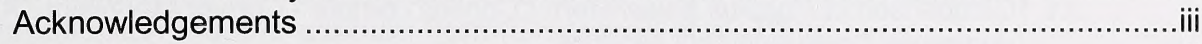

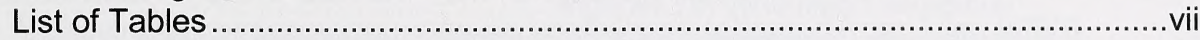

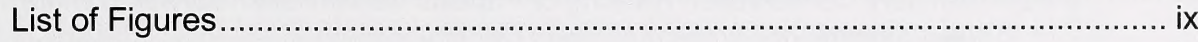

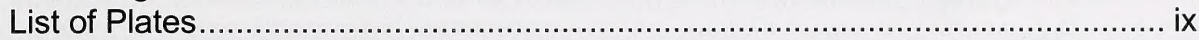

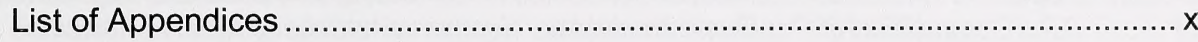

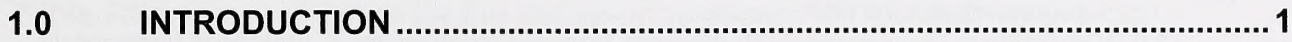

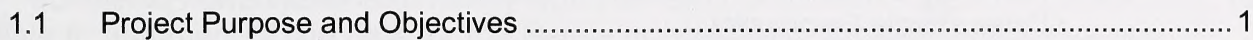

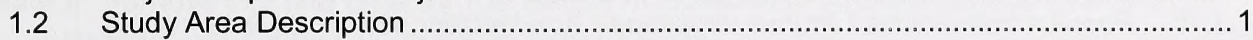

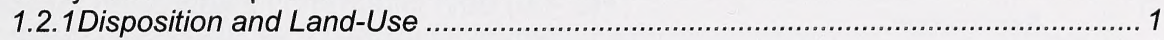

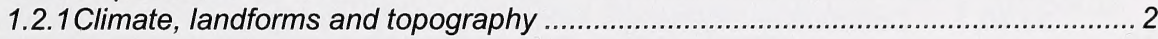

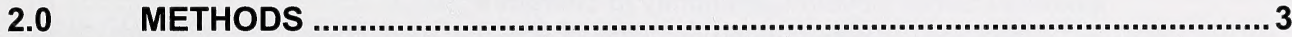

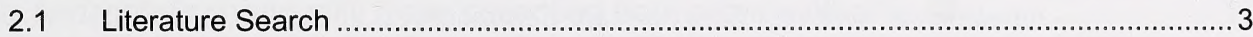

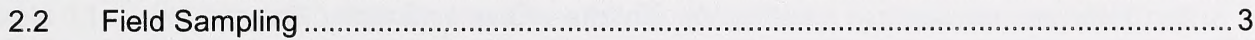

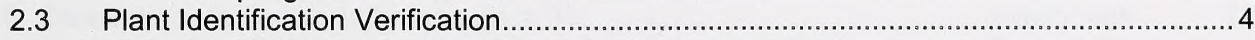

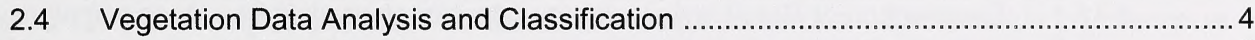

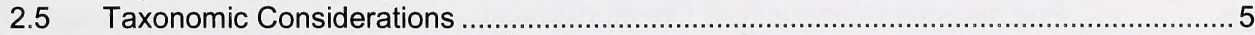

2.6 Cross-referencing of Proposed Community Types to Literature ................................6

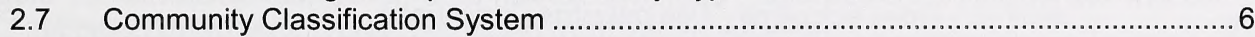

2.8 Evaluation and Assignment of Preliminary Provincial Ranking ................................. 7

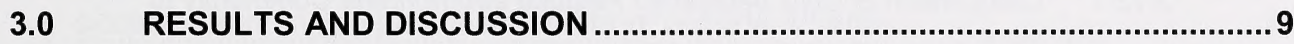

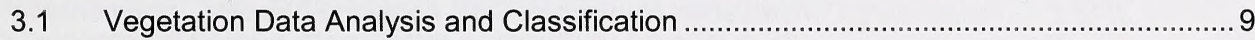

3.2 Preliminary Classification of Community Types .................................................. 12

3.2.1Description of Community Types...................................................................... 13

3.3 Betula occidentalis / Arctostaphylos uva-ursi - Juniperus horizontalis Association ...... 14

3.3.1Comparison of Betula occidentalis / Arctostaphylos uva-ursi - Juniperus horizontalis Community to Literature ............................................................... 16

3.3.2Preliminary Conservation Ranking of Betula occidentalis / Arctostaphylos uva-ursi

- Juniperus horizontalis Community ................................................................ 18

3.4 Calamovilfa longifolia - Sporobolus cryptandrus - Carex siccata Association............... 19

3.4.1Comparison of Calamovilfa longifolia - Sporobolus cryptandrus - Carex siccata Community to Literature ................................................................................. 21

3.4.2Preliminary Conservation Ranking of Calamovilfa longifolia - Sporobolus cryptandrus - Carex siccata Community ............................................................ 24

3.5 Elaeagnus commutata - Prunus virginiana / Carex siccata - Koeleria macrantha

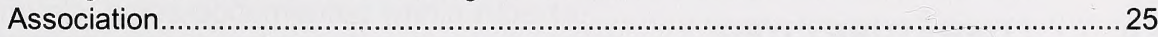

3.5.1Comparison of Elaeagnus commutata - Prunus virginiana / Carex siccata Koeleria macrantha Community to Literature.

3.6 Juniperus horizontalis / Stipa comata - Carex siccata Association ..................................... 30

3.6.1 Comparison of Juniperus horizontalis / Stipa comata - Carex siccata Community to Literature................................................................................................. 32

3.6.2Preliminary Conservation Ranking of Juniperus horizontalis / Stipa comata - Carex siccata Community ................................................................................... 34

3.7 Juniperus horizontalis / Calamovilfa longifolia - Carex pensylvanica ssp. heliophila Association..... 
3.7.1Comparison of Juniperus horizontalis / Calamovilfa longifolia - Carex pensylvanica ssp. heliophila Community to Literature 36

3.7.2Preliminary Conservation Ranking of Juniperus horizontalis / Calamovilfa longifolia - Carex pensylvanica ssp. heliophila Community 39

3.8 Populus balsamifera / Corylus cornuta - Cornus stolonifera / Aralia nudicaulis

Association.

3.8.1 Comparison of Populus balsamifera / Corylus cornuta - Cornus stolonifera / Aralia nudicaulis Community to Literature .............................................................. 41

3.8.2Preliminary Conservation Ranking of Populus balsamifera / Corylus cornuta Cornus stolonifera / Aralia nudicaulis Community............................................... 43

3.9 Populus tremuloides / Juniperus horizontalis / Carex siccata Association ................... 44

3.9.1Comparison of Populus tremuloides / Juniperus horizontalis / Carex siccata Community to Literature.... 46

3.9.2Preliminary Conservation Ranking of Populus tremuloides / Juniperus horizontalis

/ Carex siccata Community. 48

3.10 Populus tremuloides / Prunus virginiana - Amelanchier alnifolia / Carex siccata

Association.....

3.10.1 Comparison of Populus tremuloides / Prunus virginiana - Amelanchier alnifolia / Carex siccata Community to Literature. 51

3.10.2 Preliminary Conservation Ranking of Populus tremuloides / Prunus virginiana

- Amelanchier alnifolia / Carex siccata Community....

3.11 Populus tremuloides / Amelanchier alnifolia - Rosa acicularis / Poa palustris

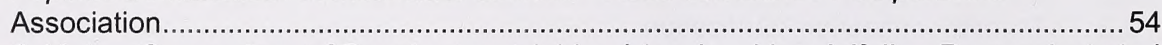

3.11.1 Comparison of Populus tremuloides / Amelanchier alnifolia - Rosa acicularis /

Poa palustris Community to Literature

3.11.2 Preliminary Conservation Ranking of Populus tremuloides / Amelanchier alnifolia - Rosa acicularis / Poa palustris Community.....

3.12 Salix bebbiana / Festuca saximontana Association 59

3.12.1 Comparison of Salix bebbiana / Festuca saximontana Community to Literature.

3.12.2 Preliminary Conservation Ranking of Salix bebbiana / Festuca saximontana Community....

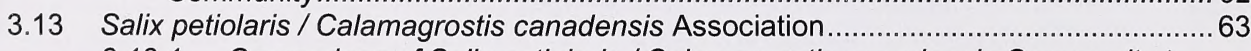

3.13.1 Comparison of Salix petiolaris / Calamagrostis canadensis Community to Literature... 64

3.13.2 Preliminary Conservation Ranking of Salix petiolaris / Calamagrostis canadensis Community

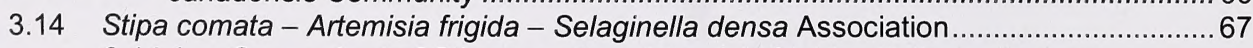

3.14.1 Comparison of Stipa comata - Artemisia frigida - Selaginella densa Community to Literature ...

3.14.2 Preliminary Conservation Ranking of Stipa comata - Artemisia frigida Selaginella densa Community..... 


\section{List of Tables}

Table 1.Summary of climatic data for the Central Parkland Natural Subregion (adapted from Achuff 1994 and Strong 1992)..................................................................

Table 2. Synonymy of plant species for the Wainwright Dunes Ecological Reserve. .......5

Table 3. Hierarchical levels and definitions for the ICEC terrestrial vegetation classification system, adapted from (Grossman et al. 1998)................................. 7

Table 4. Provincial conservation ranks and definitions (adapted from Allen 2003). ......... 8

Table 5. Sandhill and sand plain plant community types (associations) found in the Wainwright Dunes Ecological Reserve. ......................................................... 12

Table 6.Plant community similarity ratings adapted from Corns (1983) ...................... 13

Table 7.Summary statistics for the Betula occidentalis / Arctostaphylos uva-ursi Juniperus horizontalis community type $(n=3) \ldots \ldots \ldots \ldots \ldots \ldots \ldots \ldots \ldots \ldots \ldots \ldots \ldots \ldots \ldots \ldots \ldots \ldots . . .15$

Table 8. Summary of site data for the Betula occidentalis / Arctostaphylos uva-ursi -

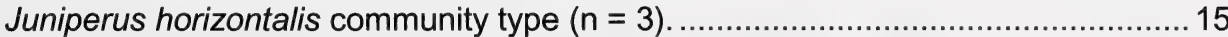

Table 9. Similarity ratings for Betula occidentalis / Arctostaphylos uva-ursi - Juniperus horizontalis community types described from within Alberta.

Table 10. Similarity ratings for Betula occidentalis / Arctostaphylos uva-ursi - Juniperus horizontalis community types described from outside Alberta.............................17

Table 11. Summary statistics for the Calamovilfa longifolia - Sporobolus cryptandrus -

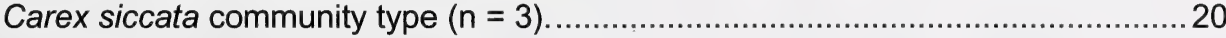

Table 12. Summary of site data for the Calamovilfa longifolia - Sporobolus cryptandrus -

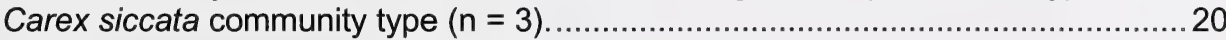

Table 13. Similarity ratings for Calamovilfa longifolia - Sporobolus cryptandrus - Carex siccata community types described from within Alberta. .....................................2 22

Table 14. Similarity ratings for Calamovilfa longifolia - Sporobolus cryptandrus - Carex siccata community types described from outside Alberta......................................2 23

Table 15. Summary statistics for the Elaeagnus commutata - Prunus virginiana / Carex siccata - Koeleria macrantha community type $(n=3) \ldots \ldots \ldots \ldots \ldots \ldots \ldots \ldots \ldots \ldots \ldots \ldots \ldots . . .26$

Table 16.Summary of site data for the Elaeagnus commutata - Prunus virginiana / Carex siccata - Koeleria macrantha community type $(n=3)$.

Table 17. Similarity rating Elaeagnus commutata - Prunus virginiana / Carex siccata Koeleria macrantha community types documented within Alberta.........................28

Table 18. Similarity rating for Elaeagnus commutata - Prunus virginiana / Carex siccata Koeleria macrantha community types documented outside Alberta. ......................29

Table 19. Summary statistics for the Juniperus horizontalis / Stipa comata - Carex siccata community type $(n=6)$.................................................................. 31

Table 20. Summary of site data for the Juniperus horizontalis / Stipa comata - Carex

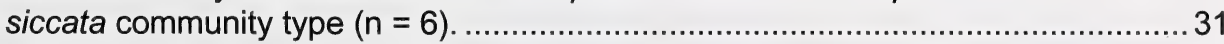

Table 21. Similarity rating for Juniperus horizontalis / Stipa comata - Carex siccata community types documented within Alberta. .................................................... 32

Table 22. Similarity rating for Juniperus horizontalis / Stipa comata - Carex siccata community types documented outside Alberta.................................................... 33

Table 23. Summary statistics for the Juniperus horizontalis / Calamovilfa longifolia Carex pensylvanica ssp. heliophila community type $(n=3) \ldots \ldots \ldots \ldots \ldots \ldots \ldots \ldots \ldots \ldots . . .36$

Table 24. Summary of site data for the Juniperus horizontalis / Calamovilfa longifolia -

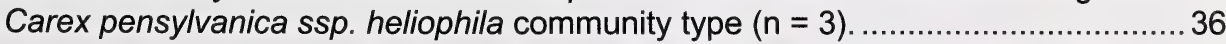

Table 25. Similarity rating for Juniperus horizontalis / Calamovilfa longifolia - Carex pensylvanica ssp. heliophila community types documented within Alberta. ............37

Table 26. Similarity rating for Juniperus horizontalis / Calamovilfa longifolia - Carex pensylvanica ssp. heliophila community types documented outside Alberta. 
Table 27.Summary statistics for the Populus balsamifera / Corylus cornuta - Cornus stolonifera / Aralia nudicaulis community type $(n=2)$.

Table 28. Summary of site data for the Populus balsamifera / Corylus cornuta - Cornus stolonifera / Aralia nudicaulis community type $(n=2)$................................... 41

Table 29. Similarity rating for Populus balsamifera / Corylus cornuta - Cornus stolonifera / Aralia nudicaulis community types documented within Alberta. .......................4 42

Table 30. Similarity rating for Populus balsamifera / Corylus cornuta - Cornus stolonifera / Aralia nudicaulis community types documented outside Alberta. ..................... 42

Table 31. Summary statistics for the Populus tremuloides / Juniperus horizontalis /

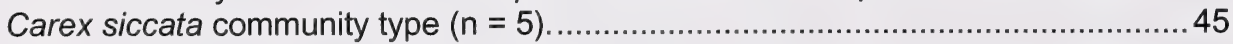

Table 32. Summary of site data for the Populus tremuloides / Juniperus horizontalis /

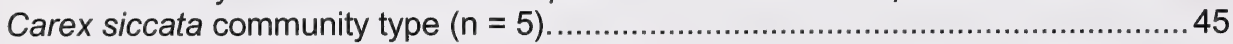

Table 33. Similarity rating for Populus tremuloides / Juniperus horizontalis / Carex siccata community types documented within Alberta.

Table 34. Similarity rating for Populus tremuloides / Juniperus horizontalis / Carex siccata community types documented outside Alberta.

Table 35. Summary statistics for the Populus tremuloides / Prunus virginiana Amelanchier alnifolia / Carex siccata community type $(n=4)$.

Table 36. Summary of site data for the Populus tremuloides / Prunus virginiana Amelanchier alnifolia / Carex siccata community type $(n=4)$.

Table 37. Similarity rating for Populus tremuloides / Prunus virginiana - Amelanchier alnifolia / Carex siccata community types documented within Alberta.

Table 38. Similarity rating for Populus tremuloides / Prunus virginiana - Amelanchier alnifolia / Carex siccata community types documented outside Alberta.

Table 39. Summary statistics for the Populus tremuloides / Amelanchier alnifolia - Rosa

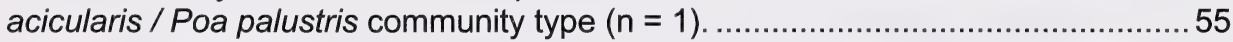

Table 40. Summary of site data for the Populus tremuloides / Amelanchier alnifolia Rosa acicularis / Poa palustris community type $(n=1)$.

Table 41. Similarity rating for Populus tremuloides / Amelanchier alnifolia - Rosa acicularis / Poa palustris community types documented within Alberta.

Table 42. Similarity rating for Populus tremuloides / Amelanchier alnifolia - Rosa acicularis / Poa palustris community types documented outside Alberta.

Table 43. Summary statistics for the Salix bebbiana / Festuca saximontana community type $(n=3)$.

Table 44. Summary of site data for the Salix bebbiana / Festuca saximontana community type $(n=3)$.

Table 45. Similarity rating for Salix bebbiana / Festuca saximontana community types documented within Alberta.

Table 46. Similarity rating for Salix bebbiana / Festuca saximontana community types documented outside Alberta.

Table 47. Summary statistics for the Salix petiolaris / Calamagrostis canadensis community type $(n=3)$.

Table 48. Summary of site data for the Salix petiolaris / Calamagrostis canadensis community type $(n=2)$.

Table 49. Similarity rating for Salix petiolaris / Calamagrostis canadensis community type documented within Alberta.

Table 50. Similarity rating for Salix petiolaris / Calamagrostis canadensis community type documented outside Alberta.

Table 51. Summary statistics for the Stipa comata - Artemisia frigida - Selaginella densa community type $(n=4)$ 
Table 52. Summary of site data for the Stipa comata - Artemisia frigida - Selaginella densa community type $(n=4)$

Table 53. Similarity rating for Stipa comata - Artemisia frigida - Selaginella densa community types documented within Alberta.

Table 54. Similarity rating for Stipa comata - Artemisia frigida - Selaginella densa community type documented outside Alberta.

\section{List of Figures}

Figure 1. Cluster analysis of 40 plots collected July - August 2003. Linkage method: Farthest Neighbour. Distance Measure: Relative Sorensen (Kulcynski). Percent Chaining $=7.46 \%$

Figure 2. Ordination diagram based on Detrended Correspondence Analysis (DCA) of 40 plots collected in July - August 2003. Total variance in the species data (inertia) 5.3428 . Eigenvector $1=0.8859$ or $16.6 \%$ of the total variance in the species data. Eigenvector $2=0.4168$ or $7.8 \%$ of the total variance in the species data.

Figure 3. Biplot based on Detrended Correspondence Analysis (DCA) of sample plots (40) and plant species (105) collected at the Wainwright Dunes Ecological Reserve in July-August 2003.

\section{List of Plates}

Plate 1. Betula occidentalis / Arctostaphylos uva-ursi - Juniperus horizontalis community type (Water birch / common bearberry - creeping juniper) Plot $34 \ldots \ldots \ldots \ldots \ldots \ldots \ldots \ldots . . . . . . . .14$

Plate 2. Calamovilfa longifolia - Sporobolus cryptandrus - Carex siccata (Sand grass sand dropseed - hay sedge) Plot 19

Plate 3. Elaeagnus commutata - Prunus virginiana / Carex siccata - Koeleria macrantha (Silverberry - chokecherry / hay sedge - june grass) Plot 31.

Plate 4. Juniperus horizontalis / Stipa comata - Carex siccata community type (Creeping juniper / needle-and-thread - hay sedge) Plot 38

Plate 5. Juniperus horizontalis / Calamovilfa longifolia - Carex pensylvanica ssp. heliophila (Creeping juniper / sand grass - sun-loving sedge) Plot 13.

Plate 6. Populus balsamifera / Corylus cornuta - Cornus stolonifera / Aralia nudicaulis community type (Balsam poplar / beaked hazelnut - red-osier dogwood / wild sarsaparilla) Plot 4

Plate 7. Populus tremuloides / Juniperus horizontalis / Carex siccata community type (Aspen / creeping juniper / hay sedge) Plot 2.

Plate 8. Populus tremuloides / Prunus virginiana - Amelanchier alnifolia / Carex siccata community type (Aspen / chokecherry - saskatoon / hay sedge) Plot 29.

Plate 9. Populus tremuloides / Amelanchier alnifolia - Rosa acicularis / Poa palustris community type (Aspen / saskatoon - prickly rose / fowl bluegrass) Plot 1.

Plate 10. Salix bebbiana / Festuca saximontana community type (Beaked willow / Rocky Mountain sedge) Plot 30. 
Plate 11. Salix petiolaris / Calamagrostis canadensis community type (Basket willow / bluejoint) Plot 12.

Plate 12. Stipa comata - Artemisia frigida - Selaginella densa community type (Needleand-thread - pasture sagewort - prairie selaginella) Plot 3

List of Appendices

Appendix 1. Glossary of Scientific and Common Plant Species Names from the Wainwright Dunes Ecological Reserve

Appendix 2. PC-ORD output from Detrended Correspondence Analysis of Plot Data 


\subsection{Introduction}

\subsection{Project Purpose and Objectives}

The Resource Data Division of Alberta Sustainable Resource Development retained Geowest Environmental Consultants Ltd. to produce a classification of sand dune and sand plain plant community types for the Wainwright Dunes Ecological Reserve, in the Central Parkland Natural Subregion of Alberta. This initiative is in support of the Alberta Natural Heritage Information Centre (ANHIC). ANHIC collects, evaluates and makes available data on elements of natural biodiversity in Alberta, including flora, fauna and native plant communities. ANHIC develops tracking lists of elements that are considered of high priority because they are rare or special in some way. ANHIC's long-term goal is to develop a list of plant community types that occur throughout the province and to attempt to identify community types that require conservation initiatives.

The objectives of this project are:

$>$ to develop a plant community classification of sand dune and sand plain plant communities of the Wainwright Dunes Ecological Reserve, representative of the Central Parkland Natural Subregion based on field survey, correlations with other surveys and any available previously-collected data

$>$ evaluate and assign a preliminary provincial conservation rank to each identified community type, based on its rarity/endemism or threats to its condition.

This was accomplished by developing a sampling protocol and subsequently collecting field data on plant communities of the sand dune and sand plain landscapes of the Wainwright Dunes Ecological Reserve. Furthermore, a comparison of defined plant community types to similar types described in previously conducted field surveys in similar landscapes in Alberta and adjacent provinces and states was completed. A similarity rating based on a scale provided by Corns (1983) is also provided.

This classification will provide a better understanding of plant community biodiversity in Alberta and will contribute to the development of a Canadian National Vegetation Classification (CNVC), the Canadian component of the International Classification of Ecological Communities (ICEC). The ICEC system has been adopted by the United States and it is a national standard for vegetation classification known as the U.S. National Vegetation Classification (USNVC).

\subsection{Study Area Description}

\subsubsection{Disposition and Land-Use}

The Wainwright Dunes Ecological Reserve is located directly south of Canadian Forces Base (CFB) Wainwright, including the following sections of land:

$>$ Township 42, Range 5, West of the $4^{\text {th }}$ Meridian, sections $2,3,4,5,9,10,11,14$, 15 and 16

Township 41, Range 5, West of the $4^{\text {th }}$ Meridian, sections 33 and 34 . 
The Wainwright Dunes Ecological Reserve is provincial Crown land, administered by Alberta Community Development. The total area comprises just over 2,800 hectares. Current land uses consist primarily of cattle grazing on native pasture. One grazing association holds the lease for grazing rights within and adjacent to the Ecological Reserve.

\subsubsection{Climate, landforms and topography}

The Wainwright Dunes Ecological Reserve is situated in the Central Parkland Natural Subregion (Achuff 1994) and is representative of the aspen parkland as well as sand dune and sand plain ecosystems of this subregion. The climate of the Central Parkland is somewhat transitional between the Boreal regions to the north and the grasslands to the south. The Central Parkland is somewhat different from the grasslands in that the majority of summer precipitation is received in July, instead of June (Strong and Leggat 1992). A summary of general climatic data is provided in Table 1.

Table 1.

Table 1.Summary of climatic data for the Central Parkland Natural Subregion (adapted from Achuff 1994 and Strong 1992).

\begin{tabular}{|l|c|}
\hline Mean Annual Temperature & $2^{\circ} \mathrm{C}$ \\
\hline Mean Summer Temperature & $13^{\circ} \mathrm{C}$ \\
\hline Mean Winter Temperature & $-9^{\circ} \mathrm{C}$ \\
\hline Total Annual Precipitation & $350-450 \mathrm{~mm}$ \\
\hline
\end{tabular}

The majority of the surficial materials in the Ecological Reserve were deposited by glacial meltwaters, which were later subjected to strong northwesterly winds. Consequently, a large complex of aeolian dunes were formed. The dunes are closely aligned in parallel ridges oriented in a northwest to southeast direction. Originally Bayrock (1958) described these dunes as longitudinal. However, they are now considered to be sand ridges of the 'North Battleford' type, formed by the transverse deflation of the southwestern wing of parabolic dunes. Ultimately, an elongate series of ridges with a somewhat sinuous crest line were formed, characterized by a strongly asymmetrical transverse profile (David 1977; Fehr 1984). Some of the dunes are steeply sided and can be up to 30 metres in height. Active blowouts are can be found scattered through the dune system (Cottonwood Consultants 1986).

Generally level sandy areas, known as outwash plains, occur along the northern and western regions and around David Lake. Outwash along the northern boundary may have been reworked by wind, giving it more topographic relief than the level outwash plains along the Ribstone Creek valley and around David Lake.

Elevations range from approximately 720 metres in the northeast corner of the reserve to 657 metres at David Lake, a difference of 63 metres. 


\subsection{Methods}

\subsection{Literature Search}

An extensive literature search was completed to locate references relating to sand dune and sand plain plant communities in Alberta. Literature related to other jurisdictions was also obtained, primarily for Saskatchewan, Manitoba, Montana, Idaho, Wyoming, North and South Dakota, Nebraska and Minnesota. Lorna Allen, of Alberta Community Development, and Harry Loonen and Patrick J. Porter of Alberta Sustainable Resource Development in Wainwright also provided many references.

\section{$2.2 \quad$ Field Sampling}

Field sampling occurred between July $14^{\text {th }}$ and August $1^{\text {st }} 2002$ following a review of the sampling strategy with Alberta Sustainable Resource Development staff. In total 40 sampling plots were established, distributed throughout a range of community types and topographic positions. Survey sites were selected based on an initial review of biophysical inventories for the survey area, as well as using aerial photographs and vegetation trends observed in the field. In most instances, a minimum of three to five plots were established in each observed community type.

Alberta Sustainable Resource Development provided guidelines for distributing and establishing sampling plots. As such, sampling plots were distributed based on the following criteria:

> one sampling plot was required to document communities considered equivalent to those identified in previous work;

D five sampling plots were required to represent major communities that were poorly correlated with those identified in previous work; and

$>$ three sampling plots were considered to be adequate when representing poorly correlated minor community types that occurred infrequently in the landscape.

Community types that were represented by fewer than three sampling plots were to be qualitatively described but considered tentative pending future data collection. As such, sampling plots were placed quite subjectively in sites considered to be 'communities.'

Vegetation and site description forms (RDB 2002-3 and RDB 2002-1 respectively) were completed at each site. The forms were completed using definitions and guidelines from Alberta Sustainable Resource Development (2003). Percent cover of vascular plant species was visually estimated in each plot, using the relevé method. All dominant, codominant and diagnostic species were recorded. Each unknown species encountered was collected for expert identification.

Plots were documented with a $35 \mathrm{~mm}$ or digital photograph to characterize the structure and composition of the plant community. The location of each survey site was determined using a Trimble GeoExplorer III unit and the locations were recorded on the site description forms. Furthermore, the location of each plot was marked on the aerial photographs. Each plot was located with a pinprick and circled and annotated on the back of the aerial photograph. 


\subsection{Plant Identification Verification}

Any unknown species encountered were labeled and collected. Kathy Tannas, of Eastern Slopes Rangeland Seeds, verified these specimens. The plot forms and digital database were updated, to reflect Ms. Tannas' findings.

\subsection{Vegetation Data Analysis and Classification}

Vegetation data were entered into an Excel spreadsheet, comprising a matrix of field plot versus plant species abundance. The final database contained 40 plots and 105 species columns. The field data spreadsheet was then imported into PC ORD version 4.20 , for classification analysis.

\section{Cluster Analysis}

The vegetation classification incorporated all stages of plant succession and was not restricted to potential or predicted climax associations, following Braun-Blanquet (1965). Cluster analysis was used to allow for a more objective classification of sand dune and sand plain communities based on species composition. A hierarchical, agglomerative clustering technique (Farthest Neighbour Analysis) was used to help identify plant community types. This clustering method progressively combines plots/samples from an individual based on their similarity until all samples are in one group (similarity analysis).

Several clustering options available in PC ORD v.4.20 were explored and the group linkage method with the lowest percent chaining (maximum information) was selected for analysis (Farthest Neighbor). The Bray-Curtis (Sorensen) and Relative Sorensen distance measures were investigated and in combination with the Farthest Neighbor group linkage method, the Relative Sorenson distance measure provided the lowest percent chaining value. Other distance measures were explored (Euclidean, Relative Euclidean), however, these measures had higher percent chaining values and seemed to introduce confusion into the clustering results.

\section{Detrended Correspondence Analysis}

Detrended correspondence analysis was also investigated to help identify plant community types. Detrended correspondence analysis (DCA) is an indirect gradient analysis/ordination technique that ordinates both species and samples (plots) concurrently (Hill and Gauch 1980). Indirect gradient analysis/ordination obtains axes characterizing major trends of environmental and community variation from calculations based on the sample data (Whittaker 1978). Conversely, direct gradient analysis (DGA) relates species directly to measured environmental factors. DCA therefore does not include analysis of environmental factors (indirect analysis), however, this data is used to help interpret and explain the results.

DCA is based on reciprocal averaging (RA) or correspondence analysis (CA). Its main advantage is that through the detrending process, an 'arch' effect is eliminated that commonly distorts the results of RA and CA. PC-ORD offers several options prior to running the ordination:

\footnotetext{
* Down-weighting rare species and

* Rescaling of axes.
} 
By down-weighting rare species in DCA, the abundances of species rarer than

\section{$\mathrm{Fmax} / 5$}

(where Fmax is the frequency of the most common species)

are down weighted in a relative amount to their frequency. Species that are more common than Fmax/5 are not down weighted (McCune and Mefford 1999). This option was selected for the analysis to capture the influence of less prevalent species in the sandhills plant community composition without overly distorting the results.

Another option presented in DCA is the rescaling of axes. Another drawback to CA (aside from the arch effect) is that the axis extremes can be condensed. In particular the distances between samples along an axis may not reflect the actual variation in species composition. This compression of the ends of the gradients is corrected in DCA by nonlinear rescaling. The non-linear rescaling is based on the average standard deviation of species turnover and follows the original version of DECORANA in multiplying the standard deviations by 100 and shifting the scales such that all scores are positive (McCune and Mefford 1999). This option was selected, using the default values in PCORD v.4.20 to eliminate the compression of species/samples at the extremes of axes.

\subsection{Taxonomic Considerations}

Plant scientific names used in this report follow Moss (1983) and Alberta Environmental Protection (1993). However, there is a discrepancy between these references and those used for the classification of ecological communities used by NatureServe, which follows A synonymized checklist and atlas with biological attributes for the vascular flora of the United States, Canada and Greenland (Kartesz 1999). A summary of the discrepancies is provided in Table 2.

Table 2. Synonymy of plant species for the Wainwright Dunes Ecological Reserve.

\begin{tabular}{|l|l|l|}
\hline \multicolumn{1}{|c|}{$\begin{array}{c}\text { Alberta Environmental Protection } \\
\text { (1993) }\end{array}$} & \multicolumn{1}{|c|}{$\begin{array}{c}\text { Kartesz (1999) / NatureServe } \\
\text { (2003) }\end{array}$} & \multicolumn{1}{c|}{ Common Name } \\
\hline Stipa comata & Hesperostipa comata & needle-and-thread \\
\hline Carex pensylvanica ssp. heliophila & Carex inops ssp. heliophila & sun-loving sedge \\
\hline Cornus stolonifera & Cornus sericea & red-osier dogwood \\
\hline
\end{tabular}

The primary concern regarding the use of synonymous species names, is when searching NatureServe for ecological communities, using scientific plant names other than those of Kartesz (1999) will yield false results. For example, searching for Stipa comata within ecological communities will return no similar plant community types. However, searching for Hesperostipa comata will return numerous related alliances and associations.

Furthermore, no attempt to standardize species and community names was made when referencing other literature. Many recent reports from the United States describe community types using Kartesz (1999) as the taxonomic reference. As such, community names described in this report may not be completely synonymous with those stated in 
the literature, although they are referring to the same species. A glossary relating scientific and common plant species names is provided in Appendix 1.

\subsection{Cross-referencing of Proposed Community Types to Literature}

Based on the review of existing literature and the development of a preliminary classification of sandhill community types, two cross-reference tables were developed. The first table cross-referenced proposed community types with similar community types previously described for Alberta. The second table cross-referenced proposed community types with similar community types identified in other jurisdictions, including Saskatchewan, Manitoba, Montana, Idaho, Wyoming, North and South Dakota, Nebraska and Minnesota. In both tables, the proposed community types are also given a similarity rating to the previously identified community types, based on a scale provided by Corns (1983) and also recently used by Coenen and Bentz (2003) and Strong (2002). The tables facilitated the identification of similar types as well as the identification of information gaps.

\subsection{Community Classification System}

Community classification for the sand dune and sand plains plant communities within the Wainwright Dunes Ecological Reserve followed the hierarchical guidelines documented in the International Classification of Ecological Communities: Terrestrial Vegetation of the United States: Volume 1 - The National Classification System: Development, Status and Application (Grossman et al. 1998). The classification system outlined in this publication organizes terrestrial vegetation into five physiognomic and two floristic levels, as shown in Table 3. 
Table 3. Hierarchical levels and definitions for the ICEC terrestrial vegetation classification system, adapted from (Grossman et al. 1998).

\begin{tabular}{|c|c|c|c|}
\hline & Hierarchical Level & \multirow{2}{*}{$\begin{array}{l}\text { Definition } \\
\text { Formation class is defined } \\
\text { based on the vegetation } \\
\text { structure of the dominant, } \\
\text { uppermost life form }\end{array}$} & \multirow[b]{2}{*}{$\begin{array}{l}\text { Levels or Examples } \\
\text { 1. ForestWhoodland: Trees with crowns overlapping (25-99\% } \\
\text { cover) } \\
\text { 2. Shrubland: Shrubs generally }>0.5 \mathrm{~m} \text { height forming }>25 \% \\
\text { cover. } \\
\text { 3. Dwarf-Shrubland: Shrubs }<0.5 \mathrm{~m} \text { height forming }>25 \% \\
\text { cover. } \\
\text { 4. Herbaceous: Graminoids, ferns and forbs dominant. } \\
\text { 5. Non-vascular: Bryophytes, lichens and algae dominant. } \\
\text { 6. Sparse: Abiotic substrate dominant }\end{array}$} \\
\hline \multirow{5}{*}{ 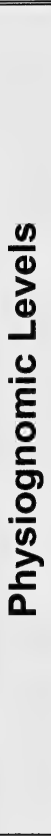 } & Formation Class & & \\
\hline & Formation Subclass & $\begin{array}{l}\text { Subclass is based on the } \\
\text { growth-form } \\
\text { characteristics of the } \\
\text { dominant life form, } \\
\text { predominantly leaf } \\
\text { phenology }\end{array}$ & $\begin{array}{l}\text { Evergreen, deciduous, mixed-deciduous for Forest Woodland, } \\
\text { Shrubland and Dwarf-Shrubland Classes. Perennial and } \\
\text { Annual for the Herbaceous class. Substrate characteristics } \\
\text { (e.g. rock, sand, cobbles, etc.) are used for the Sparse } \\
\text { vegetation class. }\end{array}$ \\
\hline & Formation Group & $\begin{array}{l}\text { Group is defined based on } \\
\text { leaf characters, the } \\
\text { presence of a woody } \\
\text { stratum or topographic } \\
\text { position. }\end{array}$ & $\begin{array}{l}\text { Broad leaf or needle leaf used for Forest/Woodland, Shrubland } \\
\text { and Dwarf-Shrubland classes. Presence of a woody stratum } \\
\text { separates groups in Herbaceous and Non-vascular classes. } \\
\text { Sparse vegetation communities are separated based on } \\
\text { topographic position (e.g. shore, cliffs, dunes, etc). }\end{array}$ \\
\hline & $\begin{array}{l}\text { Formation } \\
\text { Subgroup }\end{array}$ & $\begin{array}{l}\text { Subgroup is defined } \\
\text { based on the level of } \\
\text { anthropogenic } \\
\text { disturbance. }\end{array}$ & $\begin{array}{l}\text { All groups divide each community type into a Natural/Near } \\
\text { Natural, Semi-Natural or Planted/Cultivated subgroup. }\end{array}$ \\
\hline & Formation & $\begin{array}{l}\text { Formations represent } \\
\text { vegetation types that } \\
\text { share a definite } \\
\text { physiognomy or structure } \\
\text { within broadly defined } \\
\text { environmental factors, } \\
\text { landscape positions or } \\
\text { hydrological regimes. }\end{array}$ & e.g. Temperate or sub-polar deciduous shrubland \\
\hline$\sum_{0}^{00}$ & Alliance & $\begin{array}{l}\text { Alliance is a } \\
\text { physiognomically uniform } \\
\text { groups of plant } \\
\text { associations sharing one } \\
\text { or more diagnostic } \\
\text { species, which as a rule } \\
\text { are found in the } \\
\text { uppermost stratum of the } \\
\text { vegetation }\end{array}$ & $\begin{array}{l}\text { e.g. Populus tremuloides - Picea glauca / Linnea borealis } \\
\text { Forest Alliance } \\
\text { e.g. Carex utriculata Herbaceous Alliance }\end{array}$ \\
\hline$\frac{0}{4}$ & Association & $\begin{array}{l}\text { Association is the lowest } \\
\text { level of the hierarchy and } \\
\text { is defined as a plant } \\
\text { community type of definite } \\
\text { floristic composition, } \\
\text { uniform habitat conditions } \\
\text { and uniform physiognomy. }\end{array}$ & $\begin{array}{l}\text { Nomenclature is based on the diagnostic species. Species } \\
\text { occurring in the uppermost stratum are listed first (separated } \\
\text { by a hyphen if in the same stratum or a slash if in a different } \\
\text { strata) followed successively by those occurring in lower levels. } \\
\text { Within the same stratum, the order of species names generally } \\
\text { reflects decreasing levels of dominance or constancy. }\end{array}$ \\
\hline
\end{tabular}

\subsection{Evaluation and Assignment of Preliminary Provincial Ranking}

Each community type was evaluated and assigned a preliminary provincial ranking. The ranking system used is based on The Nature Conservancy's species ranking system (Grossman et al. 1994), as used by ANHIC (Allen 2003). The two primary criteria for developing community ranks are the total number of occurrences and the total area of each community, range-wide. Measures of geographic range, trends in status and immediate threats to the community's persistence are also considered in ranking. Preliminary ranks range from S1 (rare) to S5 (wide-spread) and are defined in Table 4. 
Table 4. Provincial conservation ranks and definitions (adapted from Allen 2003).

\begin{tabular}{|c|c|}
\hline $\begin{array}{l}\text { Preliminary } \\
\text { Rank* }^{*}\end{array}$ & Criteria \\
\hline G1(S1) & Five or fewer occurrences or very few remaining hectares \\
\hline G2(S2) & Six to 20 occurrences or few remaining hectares \\
\hline G3(S3) & $\begin{array}{l}21 \text { to } 100 \text { occurrences. May be rare and local throughout its range or found locally, even } \\
\text { abundantly, in a restricted range (e.g. a single western province or physiographic region in the } \\
\text { East) }\end{array}$ \\
\hline G4(S4) & $\begin{array}{l}\text { Apparently secure globally (State / Province wide), though it may be quite rare in parts of its range, } \\
\text { especially at the periphery. }\end{array}$ \\
\hline G5(S5) & $\begin{array}{l}\text { Demonstrably secure globally (State / Province wide) thought it might be quite rare in parts of its } \\
\text { range, especially at the periphery. }\end{array}$ \\
\hline GU(SU) & Status is uncertain \\
\hline GH(SH) & $\begin{array}{l}\text { Historic. Presumed eliminated in the province with little or no likelihood that it will be rediscovered. } \\
\text { There may be the potential for restoration. }\end{array}$ \\
\hline GX(SX) & $\begin{array}{l}\text { Believed to be eliminated throughout its range, with virtually no likelihood that it will be } \\
\text { rediscovered (e.g. American Chestnut Forest) }\end{array}$ \\
\hline GP(SP) & Potentially exists. Further documentation needed. \\
\hline G?(S?) & Element is not yet ranked. \\
\hline \multicolumn{2}{|l|}{ MODIFIERS } \\
\hline $\mathbf{Q}$ & $\begin{array}{l}\text { Can be added to any global rank to denote questionable taxonomy (e.g. G2Q }=6 \text { to } 20 \text { known } \\
\text { occurrences but questions exist concerning the classification of this type). }\end{array}$ \\
\hline$?$ & $\begin{array}{l}\text { Can be added to any rank to denote an inexact numeric rank (e.g. G1? = Believed to be } 5 \text { or less } \\
\text { occurrences but some doubt still exists concerning status). }\end{array}$ \\
\hline
\end{tabular}




\subsection{Results and Discussion}

\subsection{Vegetation Data Analysis and Classification}

Results from the agglomerative clustering methods were examined to determine the ecological meaning of the clusters and interpret the community types (Figure 1). Examination of the resulting dendrogram revealed numerous small groups. Several community types were consistently clustered together, particularly:

* Plots with high Salix petiolaris cover (plots 12, 20 and 39)

* Plots with high Elaeagnus commutata cover (plots 24, 31 and 33)

* Plots with high Populus balsamifera cover (plots 4 and 5)

\section{Wainwright Sand Dune and Sand Plain Communities}

\begin{tabular}{|c|c|c|c|c|}
\hline \multicolumn{5}{|c|}{ Distance (Objective Function) } \\
\hline $6 \mathrm{E}-03$ & $1.8 \mathrm{E}+00$ & $3.5 E+00$ & $5.2 \mathrm{E}+00$ & $7 \mathrm{E}+0 \mathrm{C}$ \\
\hline
\end{tabular}

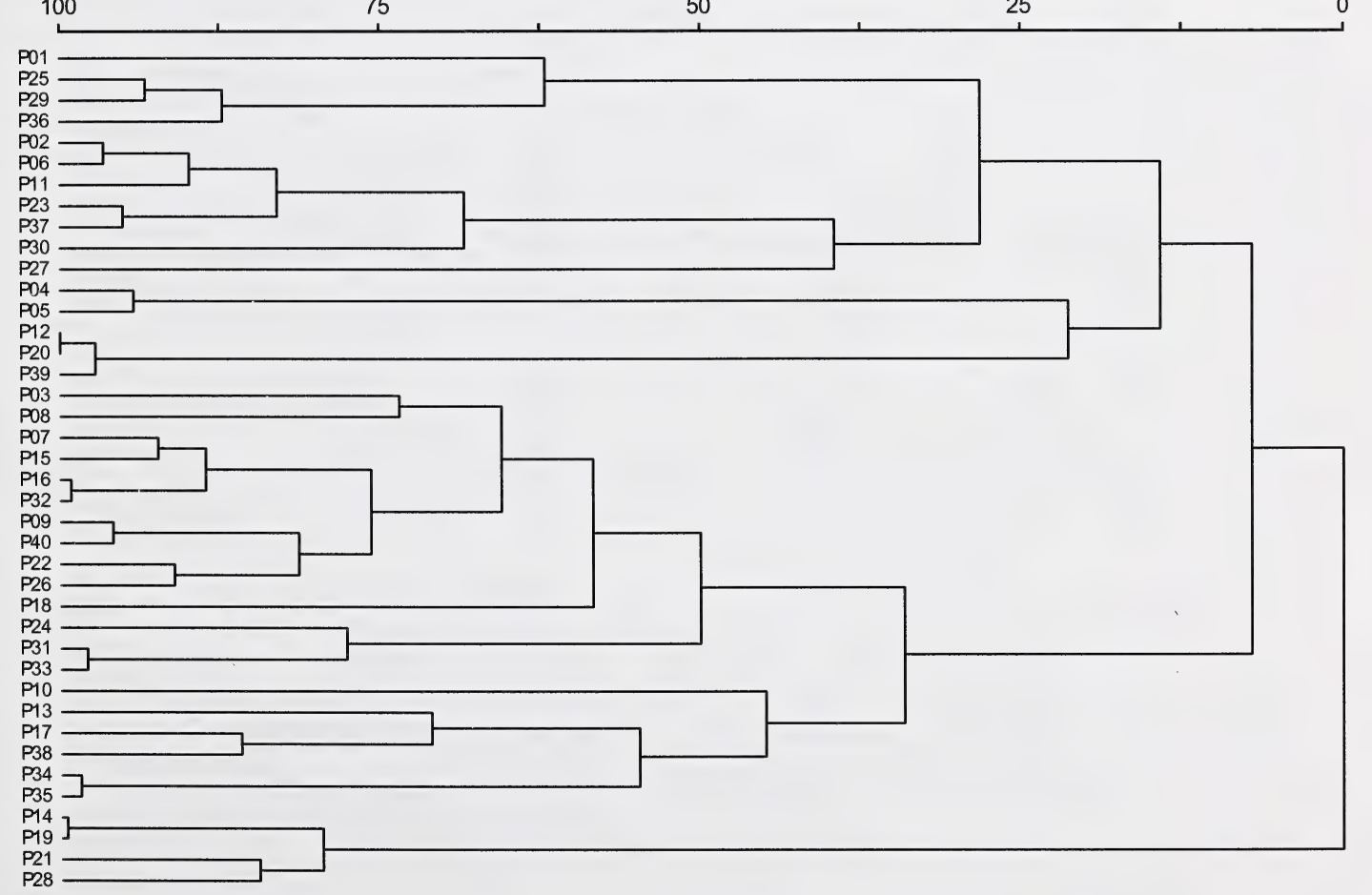

Figure 1. Cluster analysis of 40 plots collected July - August 2003. Linkage method: Farthest Neighbour. Distance Measure: Relative Sorensen (Kulcynski). Percent Chaining $=7.46 \%$. 
However, other community types, particularly aspen-dominated or grassland communities could not be easily discerned based on the cluster analysis alone.

Detrended correspondence analysis (DCA) helped to group plots with similar species compositions and also confirmed some of the community types observed from the grouping of plots in the cluster analysis. Approximately 12 groups were recognized based on the ordination of plots and species, with several 'groups' comprising only one or two sample plots as shown in Figure 2 and Figure 3. Output from the PC-ORD DCA is provided in Appendix 2.

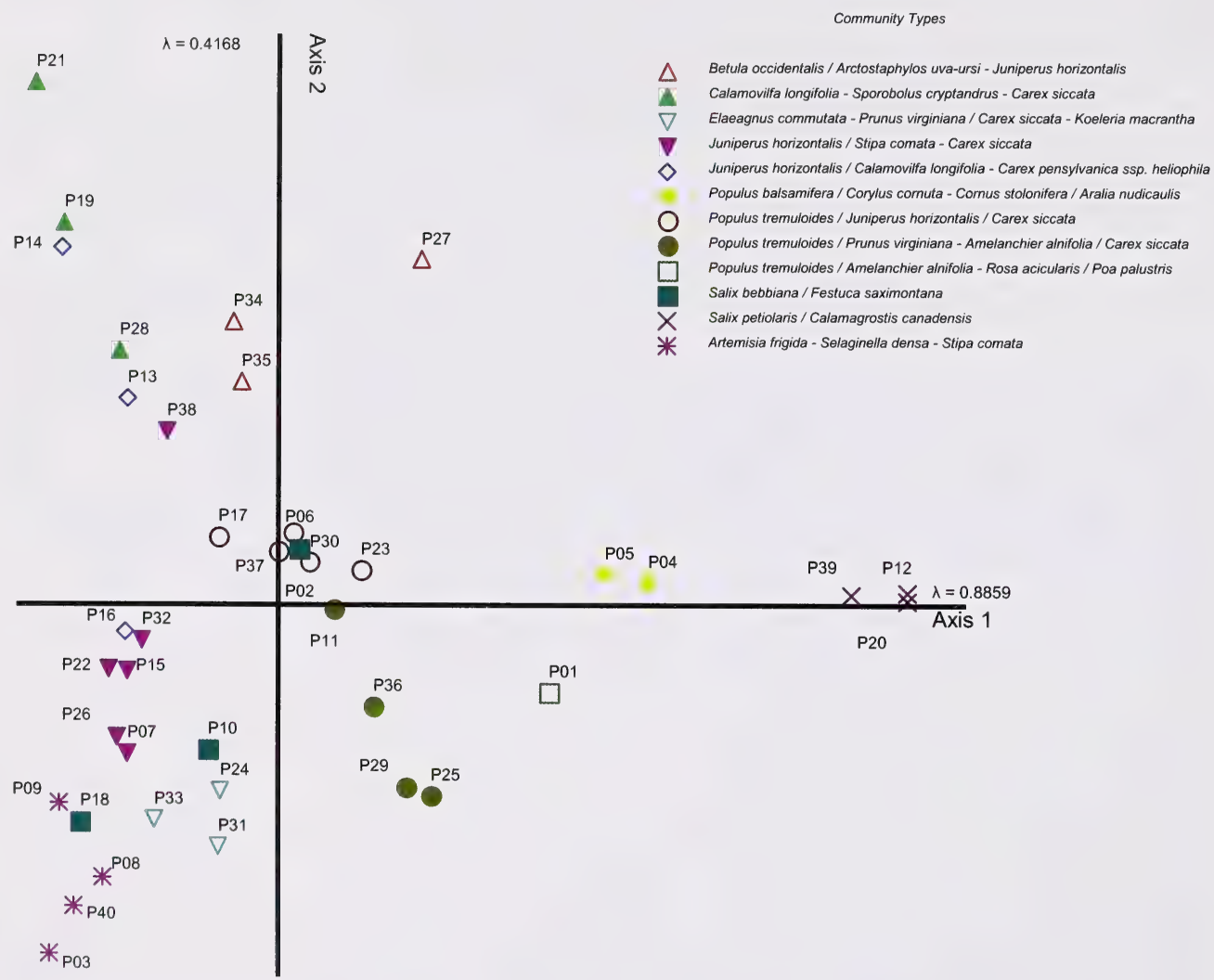

Figure 2. Ordination diagram based on Detrended Correspondence Analysis (DCA) of 40 plots collected in July - August 2003. Total variance in the species data (inertia) 5.3428 . Eigenvector $1=0.8859$ or $16.6 \%$ of the total variance in the species data. Eigenvector $2=0.4168$ or $7.8 \%$ of the total variance in the species data. 


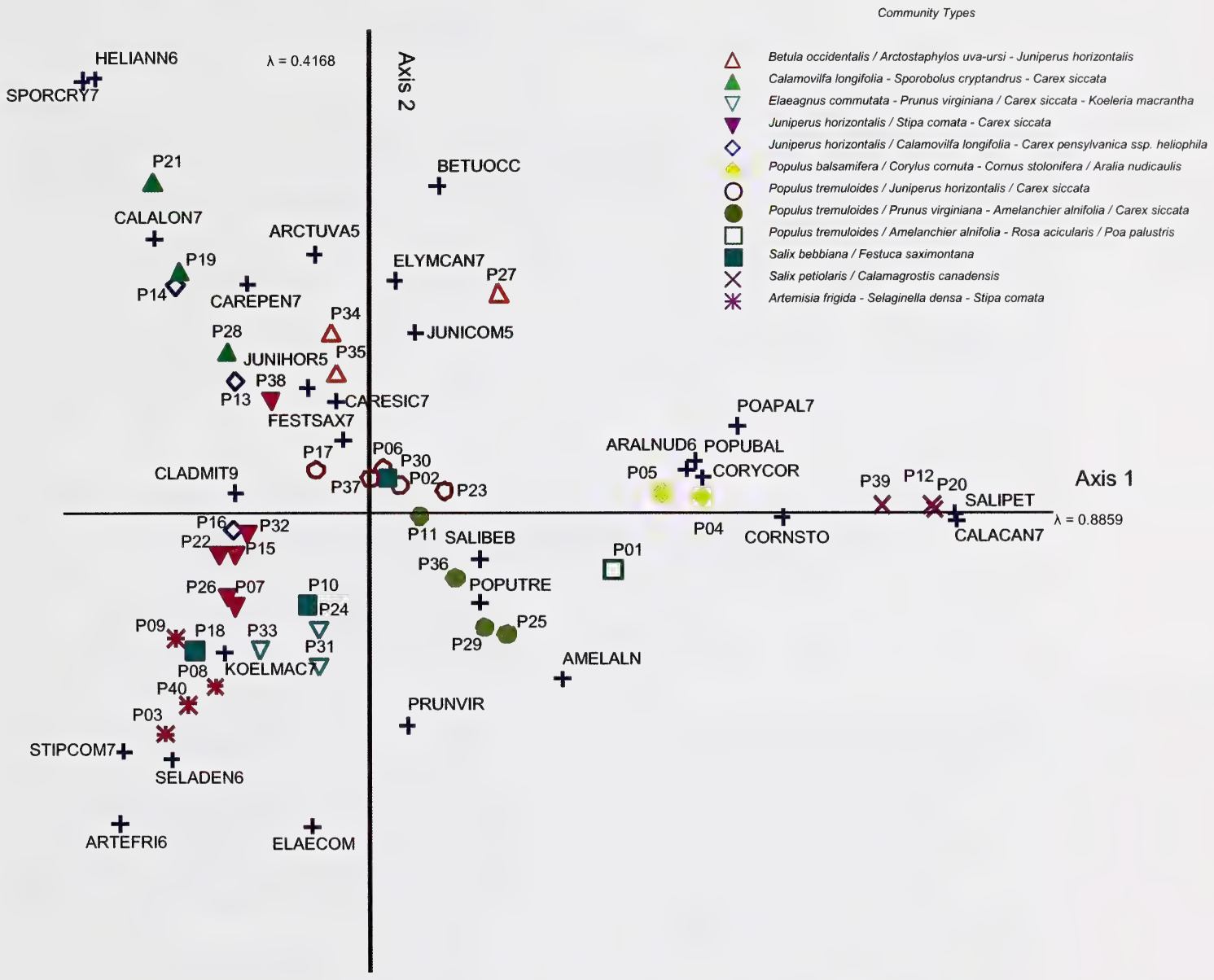

Figure 3. Biplot based on Detrended Correspondence Analysis (DCA) of sample plots (40) and plant species (105) collected at the Wainwright Dunes Ecological Reserve in July-August 2003.

Data were summarized for the resulting community types, including mean percent cover of plant species and surface substrates, standard deviation and standard error and species prominence. Species prominence was calculated using the following formula:

$$
\text { mean } \% \text { cover } x \sqrt{\% \text { presence }}
$$

A summary of site data is also provided. 


\subsection{Preliminary Classification of Community Types}

A total of 12 plant communities (associations) were found to occur in the Wainwright Dunes Ecological Reserve sand dune and sand plains areas. Community types included all classes, except sparsely vegetated and non-vascular and are presented in Table 5 by major physiognomic level.

Table 5. Sandhill and sand plain plant community types (associations) found in the Wainwright Dunes Ecological Reserve.

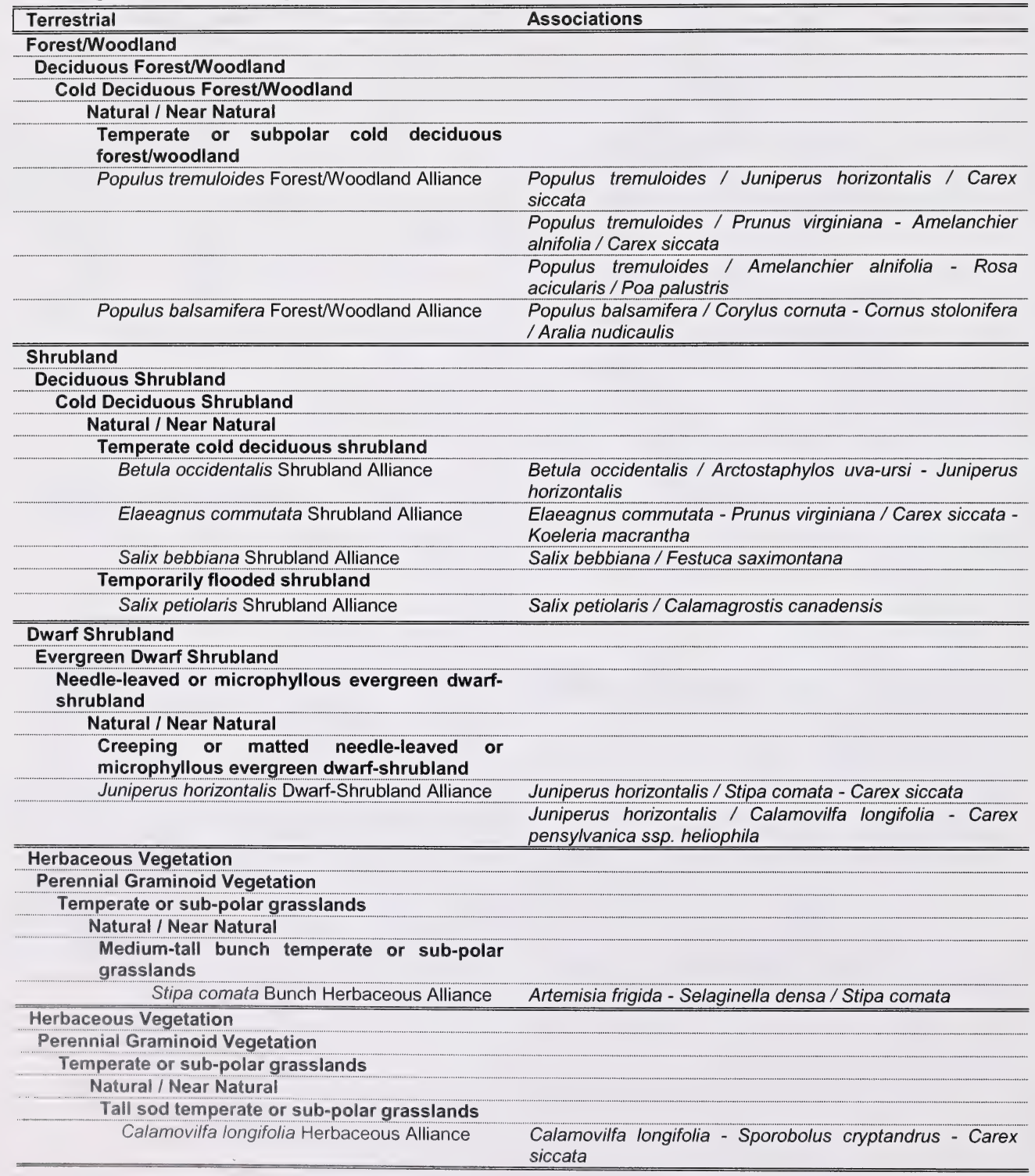




\subsubsection{Description of Community Types}

Summaries of the 12 sand dune and sand plain community types (associations) found in the Wainwright Dunes Ecological Reserves are provided in the following sections. Representative photos for each community type are provided as Plates $1-12$. A full listing of species codes is provided in Appendix 2.

Furthermore, each community type identified from the analysis of the plot data was compared against similar community types described for Alberta and other jurisdictions. Tables compare the plant community types of the Wainwright Dunes Ecological Reserve against community types described in literature from Alberta and other jurisdictions. The degree is similarity is also rated, based on a scale developed by Corns (1983) and recently applied by Coenen and Bentz (2003) and Strong (2002). Table 6 summarizes the similarity ratings from Corns (1983).

Table 6.Plant community similarity ratings adapted from Corns (1983).

\begin{tabular}{|c|l|}
\hline Rating & \multicolumn{1}{|c|}{ Description } \\
\hline 1 & Identical to or very similar \\
\hline 2 & Similar in most respects \\
\hline 3 & Several similarities but important differences \\
\hline
\end{tabular}

The amount and quality of available data used to describe the proposed sand dune and sand plain community types and assign provincial rankings differed from community to community. Furthermore, mapping of community types was not a component of this project. As such, there is no spatial context to provide an estimate of how much area each community type covers. Consequently, some community types were difficult to rank due to deficient or incomplete data and a lack of spatial context. For those communities that are ranked, more information is required to confirm the proposed rank. 


\subsection{Betula occidentalis / Arctostaphylos uva-ursi - Juniperus horizontalis Association}

Water birch / common bearberry - creeping juniper

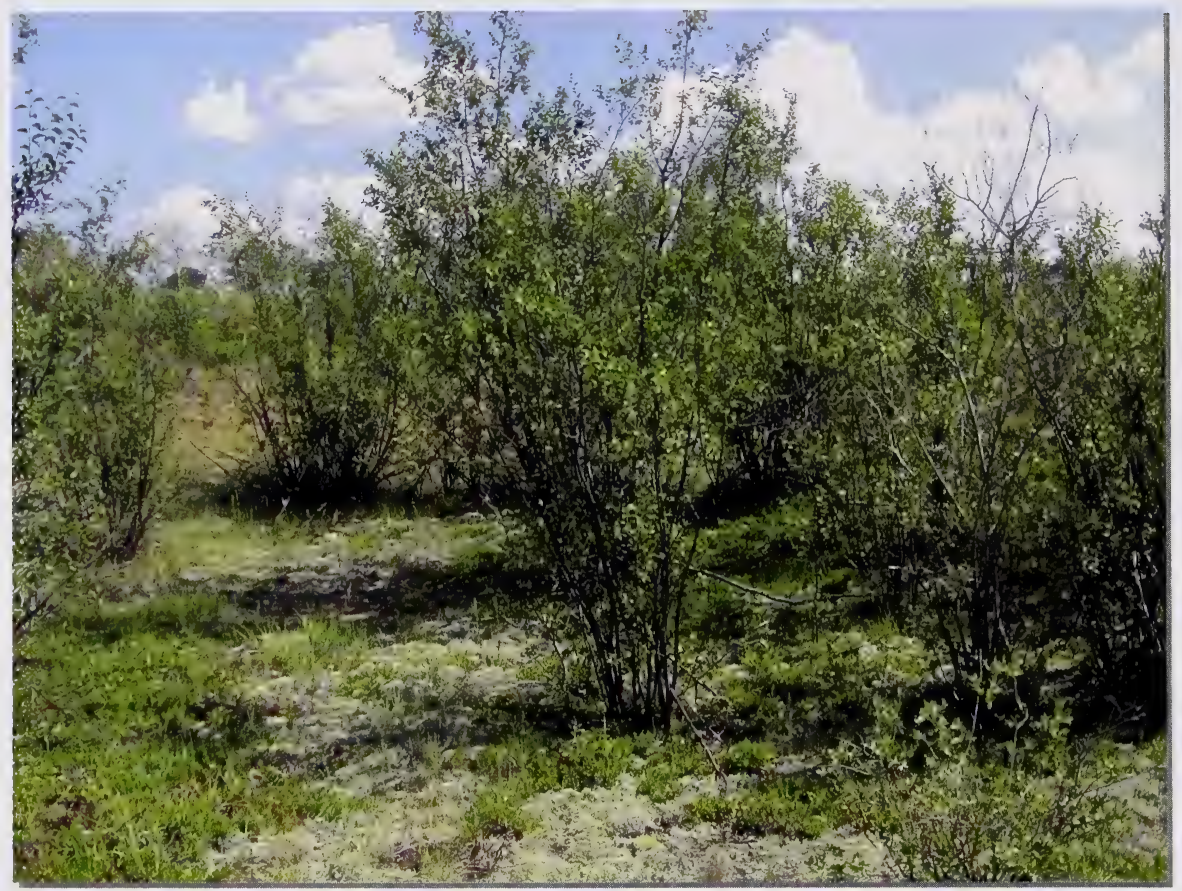

Plate 1. Betula occidentalis / Arctostaphylos uva-ursi - Juniperus horizontalis community type (Water birch / common bearberry - creeping juniper) Plot 34.

This shrubland community was dominated by Betula occidentalis in the tall shrub layer and dwarf shrub species including Arctostaphylos uva-ursi and Juniperus horizontalis in the low shrub layer. Shrub species such as Spirea alba, Juniperus communis, Salix bebbiana, and shrubby Populus tremuloides were also generally present, although typically with less than $5 \%$ cover. Forb cover was typically low, with Heterotheca villosa, Artemisia campestris and Solidago missouriensis common forb species. Carex siccata was prominent at two of the three plots surveyed, with a mean cover of $15 \%$. Calamovilfa longifolia and Carex pensylvanica ssp. heliophila were commonly present with low covers. Table 7 summarizes the species composition, mean percent cover, standard error and species prominence for this community type. 
Table 7.Summary statistics for the Betula occidentalis / Arctostaphylos uva-ursiJuniperus horizontalis community type $(n=3)$.

\begin{tabular}{lllll}
\hline \multicolumn{1}{c}{ Species } & $\begin{array}{c}\text { Mean } \% \\
\text { Cover }\end{array}$ & $\begin{array}{c}\text { Standard } \\
\text { Error }\end{array}$ & Presence & Prominence \\
\hline Betula occidentalis & 36.0 & 6.0 & 3 & 41.6 \\
\hline Carex siccata & 15.0 & 7.6 & 2 & 21.2 \\
\hline Arctostaphylos uva-ursi & 17.3 & 9.6 & 3 & 20.0 \\
\hline Cladina mitis & 11.7 & 6.0 & 2 & 16.5 \\
\hline Juniperus horizontalis & 11.0 & 4.9 & 3 & 12.7 \\
\hline Juncus balticus & 3.3 & 3.3 & 1 & 6.7 \\
\hline Poa pratensis & 3.3 & 3.3 & 1 & 6.7 \\
\hline Populus tremuloides & 3.7 & 2.0 & 2 & 5.2 \\
\hline Oryzopsis asperifolia & 2.3 & 2.3 & 1 & 4.7 \\
\hline Poa palustris & 2.3 & 2.3 & 1 & 4.7 \\
\hline Calamovilfa longifolia & 3.0 & 2.1 & 2 & 4.2 \\
\hline Festuca saximontana & 2.0 & 2.0 & 1 & 4.0 \\
\hline Schizachne purpurescens & 1.7 & 1.7 & 1 & 3.3 \\
\hline Carex pensylvanica ssp. & 2.3 & 1.5 & 2 & 3.3 \\
\hline heliophila & 2.3 & 1.5 & 2 & 3.3 \\
\hline Juniperus communis & 2.8 & 1.6 & 3 & 3.3 \\
\hline Spirea alba & & & & \\
\hline
\end{tabular}

\begin{tabular}{lllll}
\hline \multicolumn{1}{c}{ Species } & $\begin{array}{c}\text { Mean } \% \\
\text { Cover }\end{array}$ & $\begin{array}{c}\text { Standard } \\
\text { Error }\end{array}$ & Presence & Prominence \\
\hline Salix bebbiana & 2.0 & 1.5 & 2 & 2.8 \\
\hline Solidago spathulata & 1.3 & 0.7 & 2 & 1.9 \\
\hline Heterotheca villosa & 1.0 & 0.6 & 2 & 1.4 \\
\hline Carex spp. & 0.7 & 0.7 & 1 & 1.3 \\
\hline Epilobium angustifolium & 0.7 & 0.7 & 1 & 1.3 \\
\hline Koeleria macrantha & 0.7 & 0.7 & 1 & 1.3 \\
\hline Artemisia campestris & 0.7 & 0.3 & 2 & 0.9 \\
\hline Cladonia uncialis & 0.3 & 0.3 & 1 & 0.7 \\
\hline Fragaria virginiana & 0.3 & 0.3 & 1 & 0.7 \\
\hline Ribes oxyacanthoides & 0.3 & 0.3 & 1 & 0.7 \\
\hline Rosa acicularis & 0.3 & 0.3 & 1 & 0.7 \\
\hline Solidago candensis & 0.3 & 0.3 & 1 & 0.7 \\
\hline Lathyrus ochroleucus & 0.3 & 0.2 & 2 & 0.5 \\
\hline Chenopodium & 0.2 & 0.2 & 1 & 0.3 \\
\hline leptophyllum & 0.2 & 0.2 & 1 & 0.3 \\
\hline Equisetum hymenale & 0.2 & 0.2 & 1 & 0.3 \\
\hline Erysimum asperum & 0.2 & 0.2 & 1 & 0.3 \\
\hline \hline Viola adunca & & & & \\
\hline
\end{tabular}

This community was limited in aerial extent, primarily found in the east-central portions of the Ecological Reserve. It was typically found in low-lying, depressional sites between large, widely distributed sand dunes. Soils were sandy, with approximately $50 \%$ low shrub and herbaceous vegetative cover. A summary of site data is provided in Table 8.

Table 8. Summary of site data for the Betula occidentalis / Arctostaphylos uva-ursiJuniperus horizontalis community type $(n=3)$.

\begin{tabular}{cccccccccc}
\hline \hline Plot Elevation & Slope & Aspect & Drainage & $\begin{array}{c}\text { Site } \\
\text { Position }\end{array}$ & $\begin{array}{c}\text { Surface } \\
\text { Shape }\end{array}$ & $\begin{array}{c}\text { Moisture } \\
\text { Regime }\end{array}$ & $\begin{array}{c}\text { Nutrient } \\
\text { Regime }\end{array}$ \\
\hline 27 & 682 & 0 & n/a & Imperfectly & Depression & Concave & Mesic & Rich \\
\hline 34 & 683 & 0 & n/a & Well & Depression & Concave & Subxeric & Medium \\
\hline 35 & 688 & 0 & n/a & Well & Depression & Concave & Subxeric & Medium \\
\hline \hline
\end{tabular}




\subsubsection{Comparison of Betula occidentalis / Arctostaphylos uva-ursi - Juniperus horizontalis Community to Literature}

In Alberta, two Betula occidentalis community types have been identified and are listed in Table 9. A Betula occidentalis community has been reported from the Foothills Parkland and Grassland Natural regions, with some scattered occurrences in the Lower Foothills. This community was typically found on alluvial terraces, streambanks as well as on abandoned terraces along rivers and streams (Thompson and Hansen 2002). The authors noted that the water table was at the soil surface throughout the growing season. Betula occidentalis was dominant in the tall shrub layer, with Salix lutea, Cornus stolonifera, Prunus virginiana and Rosa spp. present in the lower shrub layers. Similarly, a Betula occidentalis - Amelanchier alnifolia / Artemisia campestris - Elymus lanceolatus (Agropyron dasystachyum) was found on sand dunes and swales in the Montane Natural Subregion (Allen 2003). In this community, Betula occidentalis and Amelanchier alnifolia form dense, tall patches with scattered associated species. The amount of bare sand may be as high as $90 \%$. This community, while sharing some similar site characteristics is quite different, floristically, than the community found at Wainwright. A similar Betula occidentalis-dominated community has also been found on alluvial fans, in the Lower and Upper Foothills Natural Subregions, specifically west of Hinton (Keith Ainsley, pers. comm.). This community was found on coarse-textured fluvial materials, with Juniperus horizontalis and Arctostaphylos uva-ursi being common species. While these occurrences of a related community have not been documented formally, it suggests that the distribution of this community is more widely spread, than is currently reported.

Table 9. Similarity ratings for Betula occidentalis / Arctostaphylos uva-ursi - Juniperus horizontalis community types described from within Alberta.

\begin{tabular}{|l|c|l|}
\hline \multicolumn{2}{|c|}{ Similar Communities and Citations } & $\begin{array}{c}\text { Similarity } \\
\text { Rating }\end{array}$ \\
\hline Betula occidentalis (Thompson and Hansen 2002) & 3 & $\begin{array}{l}\text { This community is different floristically and has different site } \\
\text { characteristics than that found in Wainwright. }\end{array}$ \\
\hline $\begin{array}{l}\text { Betula occidentalis - Amelanchier alnifolia / } \\
\text { Artemisia campestris - Elymus lanceolatus } \\
\text { (Agropyron dasystachyum) (Allen 2003) }\end{array}$ & 3 & $\begin{array}{l}\text { This community, while sharing some similar site } \\
\text { characteristics is quite different floristically than that found at } \\
\text { Wainwright. }\end{array}$ \\
\hline $\begin{array}{l}\text { Betula occidentalis alluvial fan community (Ainsley, } \\
\text { pers. comm.) }\end{array}$ & 1 & $\begin{array}{l}\text { This community shares several similar floristic and a site } \\
\text { characteristics to the community found in Wainwright }\end{array}$ \\
\hline
\end{tabular}

Numerous Betula occidentalis community types have been recorded outside of Alberta and are listed in Table 10. However, most of the communities differ floristically from that found within the Wainwright Dunes Ecological Reserve. Some have been identified but with too few details available to allow for proper comparison. Epp and Townley-Smith (1980) report Betula occidentalis communities from the Great Sandhills of Saskatchewan where it occurs in lower areas in the sand flats. Unfortunately the authors provide no further information. Montana lists three different Betula occidentalis natural communities for the state, (1) Betula occidentalis - Pentaphylloides floribunda, (2) Betula occidentalis / Cornus sericea, and (3) Betula occidentalis shrublands (MNHP 2002). Unfortunately, there are no associated descriptions available for these communities. Both Colorado (2001) and NatureServe (2003) also list a Betula occidentalis shrubland but unfortunately there are no additional details provided.

Several authors document a Betula occidentalis / Cornus sericea community from the U.S. midwest, where it occurs on floodplains in Wyoming and South Dakota, west to Washington, south to California and east to Utah (Faber-Langendoen et al. 2001; 
Marriott and Faber-Langendoen 2000). In this community the tall-shrub layer is dominated by Betula occidentalis with Cornus sericea often co-dominating the tall-shrub layer although it may be shorter and generally contribute less cover. Scattered Populus angustifolia may be present, although trees usually contribute less than $10 \%$ cover. Furthermore, Hansen et al. (1995) document a Betuia occidentalis riparian community from Montana, where it is found along alluvial terraces, floodplains and streambanks as well as adjacent to seeps and springs. It was typically found at low to mid elevations along high gradient streams in the eastern front, as well as in southwestern Montana. Other common species included Cornus stolonifera, Rosa woodsii, Agrostis stolonifera and Poa pratensis. Soil textures were fairly variable, ranging from loam to sandy loam.

Table 10. Similarity ratings for Betula occidentalis / Arctostaphylos uva-ursi - Juniperus horizontalis community types described from outside Alberta.

\begin{tabular}{|c|c|c|}
\hline $\begin{array}{l}\text { Similar Communities and } \\
\text { Citations }\end{array}$ & $\begin{array}{l}\text { Similarity } \\
\text { Rating }\end{array}$ & Comments \\
\hline $\begin{array}{l}\text { Betula occidentalis (Epp and Townley- } \\
\text { Smith 1980) }\end{array}$ & $?(2)$ & $\begin{array}{l}\text { This community is noted in the Great Sandhills of Saskatchewan where } \\
\text { it occurs in lower areas in the sand flats. Unfortunately no further } \\
\text { information is provided. As such it is difficult to assess the similarity. }\end{array}$ \\
\hline $\begin{array}{l}\text { Betula occidentalis - Pentaphylloides } \\
\text { floribunda Shrubland (MNHP 2002) }\end{array}$ & $?(3)$ & $\begin{array}{l}\text { This type is listed as a natural plant community for Montana, but no } \\
\text { description given thus no assessment of similarity could be done. } \\
\text { Ranked G2Q / S? }\end{array}$ \\
\hline $\begin{array}{l}\text { Betula occidentalis / Cornus sericea } \\
\text { Shrubland (MNHP 2002) }\end{array}$ & $?(3)$ & $\begin{array}{l}\text { This type is listed as a natural plant community for Montana, but no } \\
\text { description given thus no assessment of similarity could be done. } \\
\text { Ranked G3? / S? }\end{array}$ \\
\hline $\begin{array}{l}\text { Betula occidentalis Shrubland (MNHP } \\
\text { 2002) }\end{array}$ & $?(3)$ & $\begin{array}{l}\text { This type is listed as a natural plant community for Montana, but no } \\
\text { description given thus no assessment of similarity could be done. } \\
\text { Ranked G3Q / S3 }\end{array}$ \\
\hline $\begin{array}{l}\text { Betula occidentalis Shrubland (CNHP } \\
\text { 2001) }\end{array}$ & $?(3)$ & $\begin{array}{l}\text { This type is listed as a natural wetland plant community for Colorado, } \\
\text { but no description given thus no assessment of similarity could be done. } \\
\text { Ranked G3 / S2 }\end{array}$ \\
\hline $\begin{array}{l}\text { Betula occidentalis Shrubland } \\
\text { (NatureServe 2003) }\end{array}$ & $?(3)$ & $\begin{array}{l}\text { This community is described as a seasonally flooded deciduous } \\
\text { shrubland and has been recorded from Colorado, Idaho, Montana, } \\
\text { Nevada, Washington and Wyoming. Unfortunately no further description } \\
\text { is provided and an assessment of similarity is difficult to make. }\end{array}$ \\
\hline $\begin{array}{l}\text { Betula occidentalis / Cornus sericea } \\
\text { (Faber-Langendoen et al. 2001; Marriott } \\
\text { and Faber-Langendoen 2000) }\end{array}$ & 3 & $\begin{array}{l}\text { This community is quite different in terms of site characteristics and } \\
\text { floristic composition than that found in Wainwright. }\end{array}$ \\
\hline Betula occidentalis (Hansen et al. 1995) & 3 & $\begin{array}{l}\text { This community is quite different in terms of site characteristics and } \\
\text { floristic composition than that found in Wainwright. }\end{array}$ \\
\hline $\begin{array}{l}\text { Betula occidentalis - Juniperus } \\
\text { horizontalis / Calamovilfa longifolia } \\
\text { Shrubland (Faber-Langendoen et al. } \\
\text { 2001; Schneider et al. 1997) }\end{array}$ & $?(1)$ & $\begin{array}{l}\text { This community type is described from the northern Great Plains of the } \\
\text { United States and Canada specifically from Manitoba and North } \\
\text { Dakota. Unfortunately there is little information available regarding this } \\
\text { type. This community appears to be virtually identical in species } \\
\text { composition to that found in Wainwright. }\end{array}$ \\
\hline $\begin{array}{l}\text { Betula occidentalis - Juniperus } \\
\text { horizontalis / Calamovilfa longifolia } \\
\text { Shrubland (NatureServe 2003) }\end{array}$ & $?(1)$ & $\begin{array}{l}\text { This type is found in the northern Great Plains of the United States and } \\
\text { Canada. Type has been described from Manitoba and North Dakota. } \\
\text { More information is needed to clarify the concept of this type. }\end{array}$ \\
\hline
\end{tabular}

High water tables are a common characteristic. However, both of these communities have dramatically different site conditions that what was observed at the Wainwright Dunes ecological reserve.

NatureServe (2003) and several authors (Faber-Langendoen et al. 2001; Schneider et al. 1997) report a Betula occidentalis - Juniperus horizontalis / Calamovilfa longifolia Shrubland which appears to be more closely related to the community observed in Wainwright. The authors document this community type from the northern Great Plains of the United States and Canada specifically from Manitoba and North Dakota. Unfortunately there is little additional information available regarding this type. 


\subsubsection{Preliminary Conservation Ranking of Betula occidentalis / Arctostaphylos uva-ursi - Juniperus horizontalis Community}

Preliminary Rank: S2S3

A review of floristically related plant communities throughout the Aspen Parkland and Great Plains regions revealed that Betula occidentalis dominated community types have generally been documented only in riparian zones. Furthermore, the riparian communities also typically have a Cornus stolonifera component. There is a mention of a Betula occidentalis dominated community from the Great Sand Hills in Saskatchewan, but no further details are provided. Several authors document a Betula occidentalis Juniperus horizontalis / Calamovilfa longifolia community from Manitoba south through North Dakota (NatureServe 2003; Faber-Langendoen et al. 2001; Schneider et al. 1997). This community is not seasonally or periodically flooded, however more information is required to clarify the concept of this type (NatureServe 2003). Superficially, this community sounds quite similar to the community found in Wainwright. A similar Betula occidentalis-dominated community has also been found on alluvial fans, in the Lower and Upper Foothills Natural Subregions (Keith Ainsley, pers. comm.). The Foothills community was found on coarse-textured fluvial materials, with Juniperus horizontalis and Arctostaphylos uva-ursi being common species. While these occurrences of a related community have not been documented formally, it suggests that the distribution of this community is more widely spread, than is currently reported.

As such, a preliminary rank of $\mathbf{S 2 S} \mathbf{3}$ is suggested for this community type until further information becomes available. Additional plots from eolian landscapes within Alberta would help to clarify the distribution of this community type. 


\subsection{Calamovilfa longifolia - Sporobolus cryptandrus - Carex siccata Association}

Sand grass - sand dropseed - hay sedge

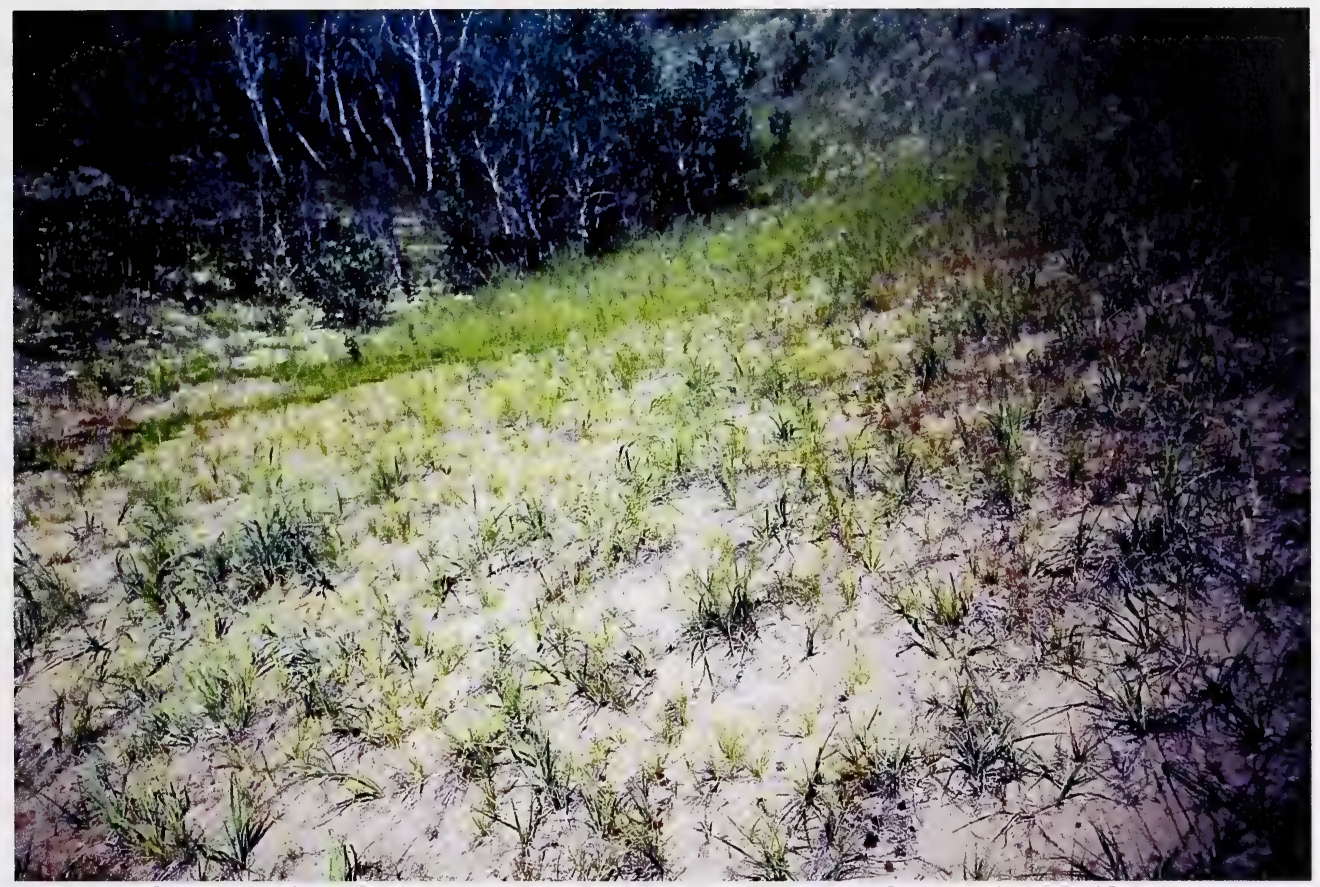

Plate 2. Calamovilfa longifolia - Sporobolus cryptandrus - Carex siccata (Sand grass sand dropseed - hay sedge) Plot 19.

This community type was co-dominated by Calamovilfa longifolia, Sporobolus cryptandrus and Carex siccata in the graminoid stratum with each species typically having a cover of greater than $15 \%$. This community was found on dune slopes where sand movement was somewhat active. Few shrub or forb species were present, although Chenopodium leptophyllum (status unknown [SU] ANHIC 2002), Heterotheca villosa, and Chenopodium pratericola were found in two of the three sites sampled. Only one shrub species, Juniperus horizontalis, was encountered at one of the survey sites, however it occurred with less than $1 \%$ cover. Other forb and graminoid species were found at different survey sites, but few were common to all or most plots. Table 11 summarizes the species composition, mean percent cover, standard error and species prominence for this community type. 
Table 11. Summary statistics for the Calamovilfa longifolia - Sporobolus cryptandrus Carex siccata community type $(n=3)$.

\begin{tabular}{llccc}
\hline \multicolumn{1}{c}{$\begin{array}{c}\text { Species } \\
\text { Calamovilfa longifolia }\end{array}$} & $\begin{array}{c}\text { Mean } \% \\
\text { Cover }\end{array}$ & $\begin{array}{c}\text { Standard } \\
\text { Error }\end{array}$ & Presence & Prominence \\
\hline $\begin{array}{l}\text { Sporobolus } \\
\text { cryptandrus }\end{array}$ & 18.3 & 5.0 & 3 & 20.0 \\
\hline Carex siccata & 16.7 & 6.7 & 3 & 18.3 \\
\hline Stipa comata & 2.3 & 1.5 & 2 & 16.7 \\
\hline Helianthus annuus & 2.0 & 1.5 & 2 & 2.9 \\
\hline Cladina mitis & 0.7 & 0.7 & 1 & 2.4 \\
\hline Elymus candensis & 0.7 & 0.7 & 1 & 1.2 \\
\hline Festuca saximontana & 0.7 & 0.7 & 1 & 1.2 \\
\hline $\begin{array}{l}\text { Juniperus } \\
\text { horizontalis }\end{array}$ & 0.7 & 0.7 & 1 & 1.2 \\
\hline
\end{tabular}

\begin{tabular}{lcccc}
\hline \multicolumn{1}{c}{ Species } & $\begin{array}{c}\text { Mean } \% \\
\text { Cover }\end{array}$ & $\begin{array}{c}\text { Standard } \\
\text { Error }\end{array}$ & Presence & Prominence \\
\hline Koeleria macrantha & 0.7 & 0.7 & 1 & 1.2 \\
\hline $\begin{array}{l}\text { Chenopodium } \\
\text { pratericola }\end{array}$ & 0.5 & 0.3 & 2 & 0.6 \\
\hline Heterotheca villosa & 0.5 & 0.3 & 2 & 0.6 \\
\hline $\begin{array}{l}\text { Equisetum hymenale } \\
\text { Chenopodium }\end{array}$ & 0.3 & 0.3 & 1 & 0.6 \\
\hline leptophyllum & 0.3 & 0.2 & 2 & 0.4 \\
\hline $\begin{array}{l}\text { Artemisia campestris } \\
\text { Chamaerhodos }\end{array}$ & 0.2 & 0.2 & 1 & 0.3 \\
\hline erecta & 0.2 & 0.2 & 1 & 0.3 \\
\hline Erysimum asperum & 0.2 & 0.2 & 1 & 0.3 \\
\hline Gaura coccinea & 0.2 & 0.2 & 1 & 0.3 \\
\hline \hline
\end{tabular}

The Calamovilfa longifolia - Sporobolus cryptandrus - Carex siccata community was found on south to southwest facing slopes of relatively active dunes. Some sand movement was evident and all sites the percentage of exposed sand exceeded $60 \%$. There was little organic matter accumulation at the soil surface. A summary of site data is provided in Table 12.

Table 12. Summary of site data for the Calamovilfa longifolia - Sporobolus cryptandrus Carex siccata community type $(n=3)$.

\begin{tabular}{cccccccccc}
\hline Plot Elevation & Slope & Aspect & Drainage Site Position & $\begin{array}{c}\text { Surface } \\
\text { Shape }\end{array}$ & $\begin{array}{c}\text { Moisture } \\
\text { Regime }\end{array}$ & $\begin{array}{c}\text { Nutrient } \\
\text { Regime }\end{array}$ \\
\hline 19 & 670 & 26 & 238 & Rapidly & Middle Slope & Straight & Xeric & Poor \\
\hline 21 & 670 & 23 & 216 & Rapidly & Middle Slope & Concave & Xeric & Poor \\
\hline 28 & 692 & 43 & 236 & Rapidly & Middle Slope & Straight & Subxeric & Poor \\
\hline \hline
\end{tabular}




\subsubsection{Comparison of Calamovilfa longifolia - Sporobolus cryptandrus - Carex siccata Community to Literature}

A number of similar communities to the Calamovilfa longifolia - Sporobolus cryptandrus - Carex siccata community have been identified in Alberta and are listed in Table 13. In a 1984 biophysical inventory of the Wainwright Dunes Ecological Reserve, Fehr noted an "active blowout" community type. Fehr described this community as having a canopy cover of herb-dwarf shrubs that averaged approximately $23 \%$. He noted that the organic matter on the soil surfaces averaged $4 \%$ while the exposed mineral at the soil surfaces averaged almost $90 \%$. Most of the plant species found in the active blowout were important colonizers of bare sand, including Carex foenea, Calamovilfa longifolia, Elymus canadensis, Oryzopsis hymenoides, Festuca saximontana, and Chrysopsis villosa. A Calamovilfa longifolia - Sporobolus cryptandrus - Koeleria macrantha - Carex obtusata community was found on sand dunes and active blowouts at Dillberry Lake Provincial Park (Meijer and Karpuk 1999). This community was noted to typically have a south to southwest facing aspect, a xeric moisture regime and Juniperus horizontalis and Heterotheca villosa as associated species. This community appears to be quite similar to that found in Wainwright, although several species are different.

In the Pakowki Sandhills in southern Alberta, two community types were identified that were similar to the Calamovilfa longifolia - Sporobolus cryptandrus - Carex siccata community found in the Wainwright Dunes Ecological Reserve:

1. Calamovilfa Iongifolia - Sporobolus cryptandrus community type (Komex 1993)

2. Sporobolus cryptandrus - Calamovilfa longifolia - Oryzopsis hymenoides community type (Coenen and Bentz 2003)

Coenen and Bentz (2003) reported that the Sporobolus cryptandrus - Calamovilfa longifolia - Oryzopsis hymenoides community was co-dominated by Sporobolus cryptandrus and Calamovilfa longifolia, with lesser amounts of Oryzopsis hymenoides. Low shrubs were present at some survey sites, however, the percent cover was quite low. A forb layer was typically present and included species such as Helianthus annuus, Lygodesmia rostrata and Heterotheca villosa. The community was typically found on gentle to moderate southeast to southwest facing dune slopes. The dunes were partially active, however vegetation growth was beginning to stabilize the dune. Typically, there was greater than $50 \%$ exposed sand at the soil surface, with very little organic matter accumulation. Additionally, a Sporobolus cryptandrus semi-active dune community type is tracked by ANHIC (Allen 2003; Thorpe and Godwin 1993) where it is known from the Dry Mixedgrass and Central Parkland subregions, occurring on partially stabilized dunes. The soils were noted to be coarse textured and rapidly drained. 
Table 13. Similarity ratings for Calamovilfa longifolia - Sporobolus cryptandrus - Carex siccata community types described from within Alberta.

\begin{tabular}{|l|c|l|}
\hline \multicolumn{1}{|c|}{ Similar Communities and Citations } & $\begin{array}{c}\text { Similarity } \\
\text { Rating }\end{array}$ & \multicolumn{1}{c|}{ Comments } \\
\hline Active blowout (Fehr 1984) & 1 & $\begin{array}{l}\text { This community description fits with the observed site characteristics } \\
\text { with few differences in species composition. }\end{array}$ \\
\hline $\begin{array}{l}\text { Calamovilfa longifolia - Sporobolus cryptandrus - } \\
\text { Koeleria macrantha - Carex obtusata (Meijer and } \\
\text { Karpuk 1999) }\end{array}$ & 1 & $\begin{array}{l}\text { This community appears to be quite similar to that found in Wainwright, } \\
\text { although several species are different. }\end{array}$ \\
\hline $\begin{array}{l}\text { Sporobolus cryptandrus - Calamovilfa longifolia - } \\
\text { Oryzopsis hymenoides community type (Coenen } \\
\text { and Bentz 2003) }\end{array}$ & 2 & $\begin{array}{l}\text { While the site characteristics of this community is quite similar to that } \\
\text { observed at Wainwright, the species composition is somewhat different. }\end{array}$ \\
\hline $\begin{array}{l}\text { Calamovilfa longifolia - Sporobolus cryptandrus } \\
\text { community type (Komex 1993) }\end{array}$ & 2 & $\begin{array}{l}\text { While the site characteristics of this community is quite similar to that } \\
\text { observed at Wainwright, the species composition is somewhat different. }\end{array}$ \\
\hline $\begin{array}{l}\text { Sporobolus cryptandrus semi-active dune (Allen } \\
\text { 2003; Thorpe and Godwin 1993) }\end{array}$ & 2 & $\begin{array}{l}\text { While the site characteristics of this community is quite similar to that } \\
\text { observed at Wainwright, the species composition is somewhat different. }\end{array}$ \\
\hline
\end{tabular}

Numerous related community types have been recorded outside of Alberta and they are listed in Table 14. However, most of the communities differ floristically from that found within the Wainwright Dunes Ecological Reserve. Some have been identified but with too few details available to allow for proper comparison. Thorpe and Godwin (1993) describe a Carex pennsylvanica - Sporobolus cryptandrus - Cyperus schwentzeii - Calamovilfa longifolia community that occurs on sparsely vegetated, active east/west oriented sand dunes in the Manito Sandhills of Saskatchewan. The soils were noted to be coarsetextured and had little to no organic matter to retain moisture. The site conditions described here were very similar to that observed in the Wainwright area. FaberLangendoen (2001; NatureServe 2003) described a Calamovilfa longifolia Hesperostipa comata community found in the central and northern Great Plains region, ranging from Colorado and Nebraska, north to Wyoming and South Dakota. The vegetation has an open canopy and is dominated by mid to tall grasses. Calamovilfa longifolia was the most prominent grass although Bouteloua gracilis, Bouteloua gracilis, Koeleria macrantha, Achnatherum hymenoides, Sporobolus cryptandrus and Hesperostipa comata are quite common. Sedges are reported to be uncommon but may include Carex inops ssp. heliophila. This community was frequently found on stabilized sand dunes, as well as in interdunal valleys or draws.

Several authors have described a Calamovilfa longifolia - Carex inops ssp. heliophila community type from the northwestern Great Plains, ranging from the western Dakotas to Montana and Saskatchewan (NatureServe 2003; Faber-Langendoen 2001; Schneider et al. 1997). The vegetation structure is somewhat open, with total cover averaging $65 \%$. Graminoids were dominant, with Calamovilfa longifolia as the dominant tall grass although Koeleria macrantha, Schizachyrium scoparium and Hesperostipa comata could also be present. The short-grass layer was composed primarily of Carex filifolia and Carex inops ssp. heliophila. Forb species diversity was noted to be moderate, and often included Artemisia dracunculus, Artemisia frigida, Artemisia ludoviciana, Chenopodium album, Chenopodium leptophyllum, Lathyrus spp., Liatris punctata, Lygodesmia juncea, Phlox hoodii and Psoralidium lanceolatum although they do not contribute much cover. This community was typically found on gently rolling uplands with gentle to moderate slopes $(0-20 \%$, up $39 \%)$ with sandy, sandy loam, or loamy sand soils. 
Table 14. Similarity ratings for Calamovilfa longifolia - Sporobolus cryptandrus - Carex siccata community types described from outside Alberta.

\begin{tabular}{|c|c|c|}
\hline $\begin{array}{l}\text { Similar Communities and } \\
\text { Citations }\end{array}$ & $\begin{array}{l}\text { Similarity } \\
\text { Rating }\end{array}$ & Comments \\
\hline $\begin{array}{l}\text { Carex pennsylvanica - Sporobolus } \\
\text { cryptandrus - Cyperus schwentzeii - } \\
\text { Calamovilfa longifolia on active sand } \\
\text { (Thorpe and Godwin 1993) }\end{array}$ & 1 & $\begin{array}{l}\text { Site conditions very similar, almost identical. However the floristic } \\
\text { composition was slightly different (more variable grass species). }\end{array}$ \\
\hline $\begin{array}{l}\text { Calamovilfa longifolia - Hesperostipa } \\
\text { comata Herbaceous Vegetation } \\
\text { (NatureServe 2003; Faber-Langendoen } \\
\text { 2001) }\end{array}$ & 2 & $\begin{array}{l}\text { This community shares some floristic similarities and general site } \\
\text { characteristics observed in Wainwright. }\end{array}$ \\
\hline $\begin{array}{l}\text { Calamovilfa longifolia - Carex inops } \\
\text { ssp. heliophila Herbaceous Vegetation } \\
\text { (NatureServe 2003; Faber-Langendoen } \\
\text { 2001; Schneider et al. 1997) }\end{array}$ & 2 & $\begin{array}{l}\text { This community shares many floristic similarities and matches the site } \\
\text { characteristics observed in Wainwright. }\end{array}$ \\
\hline $\begin{array}{l}\text { Calamovilfa longifolia / Carex heliophila } \\
\text { (Hansen and Hoffman 1988) }\end{array}$ & 2 & $\begin{array}{l}\text { This community shares many floristic similarities and matches the site } \\
\text { characteristics observed in Wainwright. }\end{array}$ \\
\hline $\begin{array}{l}\text { Calamovilfa longifolia - Andropogon } \\
\text { hallii (Schneider et al. 1997) }\end{array}$ & $?(3)$ & $\begin{array}{l}\text { No description of community type is given, thus cannot assess } \\
\text { similarity. However, superficially it appears to be floristically quite } \\
\text { different. }\end{array}$ \\
\hline $\begin{array}{l}\text { Calamovilfa longifolia - Carex filifolia } \\
\text { (Schneider et al. 1997) }\end{array}$ & $?(3)$ & $\begin{array}{l}\text { No description of community type is given, thus cannot assess } \\
\text { similarity. However, superficially it appears to be floristically quite } \\
\text { different. }\end{array}$ \\
\hline $\begin{array}{l}\text { Calamovilfa longifolia - Oryzopsis } \\
\text { hymenoides (Schneider et al. 1997) }\end{array}$ & ?(3) & $\begin{array}{l}\text { No description of community type is given, thus cannot assess } \\
\text { similarity. However, superficially it appears to be floristically quite } \\
\text { different. }\end{array}$ \\
\hline $\begin{array}{l}\text { Sandgrass Type (Hanson and Whitman } \\
\text { 1938) }\end{array}$ & 2 & $\begin{array}{l}\text { There are a number of floristic similarities although the site conditions } \\
\text { are somewhat different although on a sandy substrate. }\end{array}$ \\
\hline $\begin{array}{l}\text { Calamovilfa longifolia - Carex inops } \\
\text { ssp. heliophila (MNHP 2002) }\end{array}$ & $?(2)$ & $\begin{array}{l}\text { This type is listed as a natural plant community for Montana, but no } \\
\text { description given thus no assessment of similarity could be done. } \\
\text { Ranked G3 / S3? }\end{array}$ \\
\hline $\begin{array}{l}\text { Calamovilfa longifolia - Stipa comata } \\
\text { (MNHP 2002) }\end{array}$ & ? (3) & $\begin{array}{l}\text { This type is listed as a natural plant community for Montana, but no } \\
\text { description given thus no assessment of similarity could be done. } \\
\text { Ranked G3 / S3 }\end{array}$ \\
\hline
\end{tabular}

Hansen and Hoffman (1988) documented a Calamovilfa longifolia / Carex heliophila community from the Custer National Forest in Montana and South Dakota, where it occurs on rolling landscapes. Where this community was found in an undisturbed state, little other than the two dominant species occur although occasional plants of Bouteloua gracilis, Koeleria macrantha and Artemisia Iudoviciana did occur generally with low covers. The soil textures in this community ranged from sandy loams to sands. Schneider et al. (1997; NatureServe 2003) documented three different community types, all dominated by Calamovilfa longifolia. A Calamovilfa longifolia - Andropogon hallii community is recorded from Manitoba, Montana, North and South Dakota and Saskatchewan, a Calamovilfa longifolia - Carex filifolia community is noted from Montana, North and South Dakota and Wyoming, and a Calamovilfa longifolia Oryzopsis hymenoides community from Saskatchewan is also documented. Unfortunately no further details are provided, detailing their composition or site conditions.

Hanson and Whitman (1938) described a Sandgrass Type from North Dakota where it is found on residual, sandy hills and ridges. Common species included Calamovilfa longifolia Carex filifolia, C. stenophylla, C. pensylvanica, Bouteloua gracilis, Stipa comata, and Koeleria cristata. The Montana Natural Heritage Program (2002) lists two sand grass communities from Montana; (1) Calamovilfa longifolia - Carex inops ssp. heliophila and (2) Calamovilfa Iongifolia - Stipa comata. Unfortunately, no further details were provided. 


\subsubsection{Preliminary Conservation Ranking of Calamovilfa longifolia - Sporobolus cryptandrus - Carex siccata Community \\ Preliminary Rank: $\mathbf{S 2 S 3}$}

This community appears to be documented in several sources, through Alberta, Saskatchewan and the Great Plains states. The main limitation to the occurrence of this community is the availability and size of appropriate habitat, namely active sand dunes and blowouts. As such, there is a significant limitation to the expected distribution of this community type. A preliminary rank of $\mathbf{S} \mathbf{S} \mathbf{3}$ is suggested for this community type. 


\subsection{Elaeagnus commutata - Prunus virginiana / Carex siccata - Koeleria macrantha Association}

Silverberry - chokecherry / hay sedge - june grass

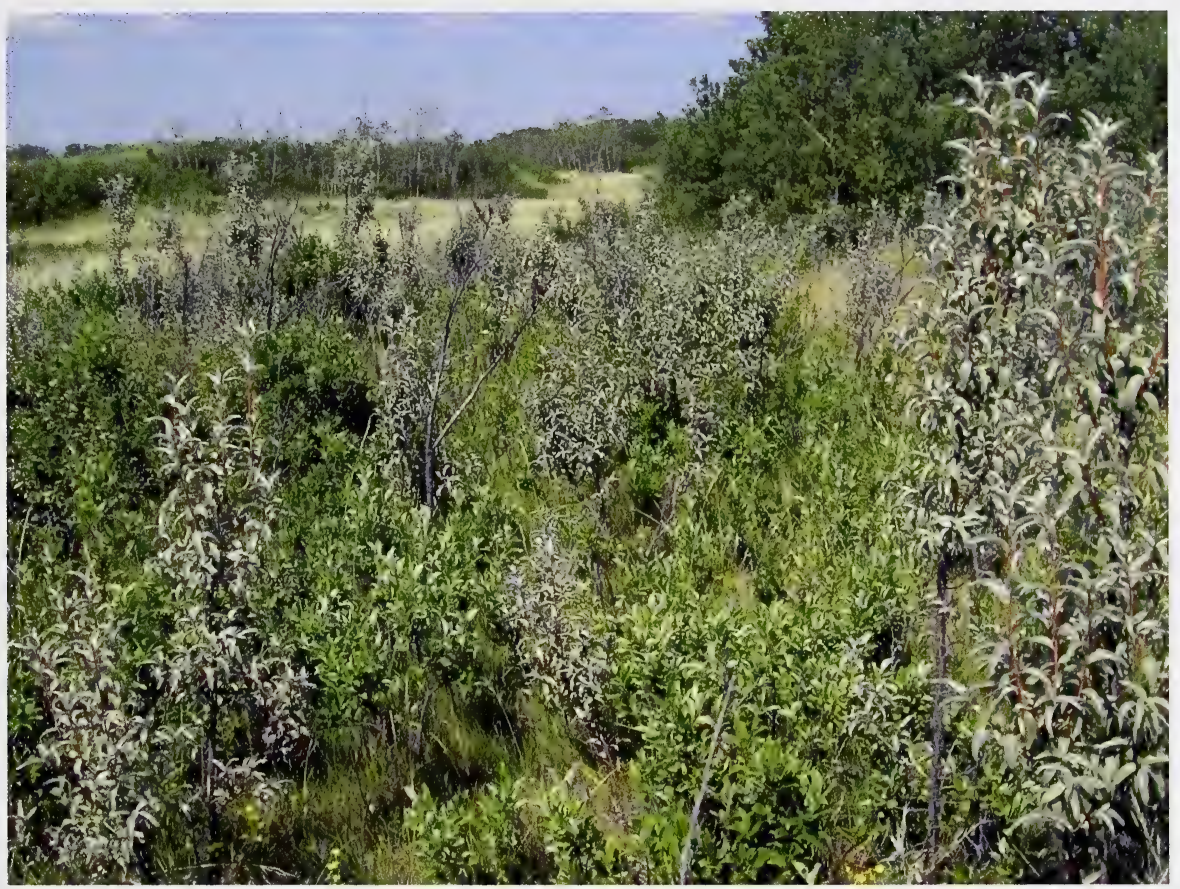

Plate 3. Elaeagnus commutata - Prunus virginiana / Carex siccata - Koeleria macrantha (Silverberry - chokecherry / hay sedge - june grass) Plot 31.

The Elaeagnus commutata - Prunus virginiana / Carex siccata - Koeleria macrantha community was very limited in aerial extent within the Wainwright Dunes Ecological Reserve. Elaeagnus commutata and Prunus virginiana are co-dominant mid-shrub species that characterize this community. Carex siccata was the dominant graminoid species, typically with greater than $15 \%$ cover, although Koeleria macrantha was present at each site sampled with a cover greater than $5 \%$. Other graminoid species included Calamovilfa longifolia, Stipa spartea, and Agrostis scabra, although typically with a mean percent cover of less than $5 \%$. Selaginella densa, Artemisia campestris, Solidago missouriensis, Lepidium densiflorum and Equisetum hymenale were also recurring species with less than $5 \%$ cover. Table 15 summarizes the species composition, mean percent cover, standard error and species prominence for this community type. 
Table 15. Summary statistics for the Elaeagnus commutata - Prunus virginiana / Carex siccata - Koeleria macrantha community type $(n=3)$.

\begin{tabular}{|c|c|c|c|c|c|}
\hline Species & $\begin{array}{c}\text { Mean } \% \\
\text { Cover }\end{array}$ & $\begin{array}{l}\text { Standard } \\
\text { Deviation }\end{array}$ & $\begin{array}{l}\text { Standard } \\
\text { Error }\end{array}$ & Presence & Prominence \\
\hline $\begin{array}{l}\text { Elaeagnus } \\
\text { commutata } \\
\end{array}$ & 21.7 & 11.5 & 6.7 & 3 & 21.7 \\
\hline Carex siccata & 18.3 & 2.9 & 1.7 & 3 & 18.3 \\
\hline $\begin{array}{l}\text { Prunus } \\
\text { virginiana }\end{array}$ & 15.2 & 12.9 & 7.5 & 3 & 15.2 \\
\hline $\begin{array}{l}\text { Koeleria } \\
\text { macrantha }\end{array}$ & 8.3 & 2.9 & 1.7 & 3 & 8.3 \\
\hline Stipa comata & 5.7 & 8.1 & 4.7 & 2 & 6.9 \\
\hline $\begin{array}{l}\text { Populus } \\
\text { tremuloides }\end{array}$ & 4.3 & 5.1 & 3.0 & 2 & 5.3 \\
\hline $\begin{array}{l}\text { Calamovilfa } \\
\text { longifolia }\end{array}$ & 4.7 & 2.5 & 1.5 & 3 & 4.7 \\
\hline $\begin{array}{l}\text { Selaginella } \\
\text { densa }\end{array}$ & 4.3 & 1.2 & 0.7 & 3 & 4.3 \\
\hline Stipa spartea & 4.0 & 2.6 & 1.5 & 3 & 4.0 \\
\hline $\begin{array}{l}\text { Symphoricarpos } \\
\text { occidentalis }\end{array}$ & 1.7 & 2.9 & 1.7 & 1 & 2.9 \\
\hline $\begin{array}{l}\text { Bouteloua } \\
\text { gracilis }\end{array}$ & 2.3 & 2.5 & 1.5 & 2 & 2.9 \\
\hline Poa pratensis & 2.3 & 2.5 & 1.5 & 2 & 2.9 \\
\hline Cladina mitis & 2.3 & 0.6 & 0.3 & 3 & 2.3 \\
\hline $\begin{array}{l}\text { Amelanchier } \\
\text { alnifolia }\end{array}$ & 1.3 & 2.3 & 1.3 & 1 & 2.3 \\
\hline $\begin{array}{l}\text { Artemisia } \\
\text { campestris }\end{array}$ & 2.0 & 2.6 & 1.5 & 3 & 2.0 \\
\hline $\begin{array}{l}\text { Solidago } \\
\text { missouriensis }\end{array}$ & 2.0 & 1.0 & 0.6 & 3 & 2.0 \\
\hline Agrostis scabra & 1.7 & 1.2 & 0.7 & 3 & 1.7 \\
\hline Rosa arkansana & 1.7 & 0.6 & 0.3 & 3 & 1.7 \\
\hline
\end{tabular}

\begin{tabular}{|c|c|c|c|c|c|}
\hline Species & $\begin{array}{c}\text { Mean } \% \\
\text { Cover }\end{array}$ & $\begin{array}{l}\text { Standard } \\
\text { Deviation }\end{array}$ & $\begin{array}{l}\text { Standard } \\
\text { Error }\end{array}$ & Presence & Prominence \\
\hline $\begin{array}{l}\text { Heterotheca } \\
\text { villosa }\end{array}$ & 1.3 & 1.2 & 0.7 & 2 & 1.6 \\
\hline Artemisia frigida & 1.0 & 1.0 & 0.6 & 2 & 1.2 \\
\hline $\begin{array}{l}\text { Solidago } \\
\text { spathulata }\end{array}$ & 0.7 & 1.2 & 0.7 & 1 & 1.2 \\
\hline $\begin{array}{l}\text { Lepidium } \\
\text { densiflorum }\end{array}$ & 1.0 & 0.9 & 0.5 & 3 & 1.0 \\
\hline $\begin{array}{l}\text { Equisetum } \\
\text { hymenale }\end{array}$ & 0.8 & 0.3 & 0.2 & 3 & 0.8 \\
\hline $\begin{array}{l}\text { Artemisia } \\
\text { ludoviciana }\end{array}$ & 0.7 & 0.6 & 0.3 & 2 & 0.8 \\
\hline $\begin{array}{l}\text { Anemone } \\
\text { multifida }\end{array}$ & 0.3 & 0.6 & 0.3 & 1 & 0.6 \\
\hline Arabis holboellii & 0.3 . & 0.6 & 0.3 & 1 & 0.6 \\
\hline Carex filifolia & 0.3 & 0.6 & 0.3 & 1 & 0.6 \\
\hline $\begin{array}{l}\text { Chenopodium } \\
\text { pratericola }\end{array}$ & 0.3 & 0.6 & 0.3 & 1 & 0.6 \\
\hline $\begin{array}{l}\text { Festuca } \\
\text { saximontana }\end{array}$ & 0.3 & 0.6 & 0.3 & 1 & 0.6 \\
\hline $\begin{array}{l}\text { Hackelia } \\
\text { americana }\end{array}$ & 0.3 & 0.6 & 0.3 & 1 & 0.6 \\
\hline $\begin{array}{l}\text { Helianthus } \\
\text { annuus }\end{array}$ & 0.3 & 0.6 & 0.3 & 1 & 0.6 \\
\hline $\begin{array}{l}\text { Erysimum } \\
\text { asperum }\end{array}$ & 0.3 & 0.3 & 0.2 & 2 & 0.4 \\
\hline $\begin{array}{l}\text { Descurainia } \\
\text { sophia }\end{array}$ & 0.2 & 0.3 & 0.2 & 1 & 0.3 \\
\hline Gaura coccinea & 0.2 & 0.3 & 0.2 & 1 & 0.3 \\
\hline $\begin{array}{l}\text { Silene } \\
\text { drummondii }\end{array}$ & 0.2 & 0.3 & 0.2 & 1 & 0.3 \\
\hline
\end{tabular}

This community type was typically found on lower slope to depressional landscape positions and generally had a level to concave surface shape. Sites had some organic matter accumulation at the soil surface, but small patches of expose sand were visible in some sites. A summary of site data is provided in Table 16.

Table 16.Summary of site data for the Elaeagnus commutata - Prunus virginiana / Carex siccata - Koeleria macrantha community type $(n=3)$.

\begin{tabular}{ccccccccc}
\hline Plot Elevation & Slope & Aspect & Drainage & Site Position & $\begin{array}{c}\text { Surface } \\
\text { Shape }\end{array}$ & $\begin{array}{c}\text { Moisture } \\
\text { Regime }\end{array}$ & $\begin{array}{c}\text { Nutrient } \\
\text { Regime }\end{array}$ \\
\hline 24 & 670 & 0 & n/a & Moderately Well & Depression & Concave & Submesic & Medium \\
\hline 31 & 707 & 3 & 218 & Well & Toe & Concave & Submesic & Medium \\
\hline 33 & 709 & 13 & 212 & Well & Lower Slope & Straight & Subxeric & Poor \\
\hline \hline
\end{tabular}




\subsubsection{Comparison of Elaeagnus commutata - Prunus virginiana / Carex siccata - Koeleria macrantha Community to Literature}

A number of Elaeagnus commutata community types have been reported in Alberta and elsewhere and are listed in Table 17. However, none are considered to be the same as the one identified in the in the Wainwright Dunes Ecological Reserve. Fehr described a slightly different Elaeagnus commutata/ Symphoricarpos occidentalis - Rosa woodsii / Poa palustris community from a 1984 survey of the Wainwright Dunes Ecological Reserve. This community was found typically in subxeric and submesic locations where drainage was good. Low shrub cover averaged $80 \%$ and the herb-dwarf shrub cover averaged $50 \%$. Elaeagnus commutata generally had $40 \%$ cover and was the only tall shrub present. The low shrub layer included buckbrush, Rosa woodsii and Ribes oxyacanthoides. Another Elaeagnus commutata community type has been described from three locations in the Central Parkland by several authors (Meijer and Karpuk 1999; Fehr 1982; Bradley and Bradley 1972). Typically Elaeagnus commutata contributed at least $50 \%$ cover, occurring as low shrublands and shrubby meadows as a fringe around saline lakes adjacent to marshes or graminoid meadows. Common associated species included Symphoricarpos occidentalis, Rosa acicularis, Carex spp., Calamovilfa longifolia, and Agropyron trachycaulum.

Adams et al. (1997) documented an Elaeagnus commutata / Stipa comata community type from the CFB Suffield National Wildlife Area, in southern Alberta. There was no information provided, as far as its floristic composition and site characteristics, as it was considered to be minor or indistinct community that would be further developed with additional field sampling. Several communities have been described from the Pakowki Sandhills area, specifically an Elaeagnus commutata / Glycyrrhiza lepidota and an Elaeagnus commutata / Artemisia ludoviciana / Calamovilfa longifolia community type (Coenen and Bentz 2003; Komex 1993). The Elaeagnus commutata / Glycyrrhiza lepidota community also included associated forbs such as Artemisia ludoviciana, Thermopsis rhombifolia, Cryptantha fendleri and Chenopodium pratericola. Juncus balticus was noted to be the dominant graminoid species, although other species such as Stipa comata, Koeleria macratha and Agropyron dasystachyum were also present. These community types occurred in depressional locations on the windward side of dunes, with well-drained soils. The Elaeagnus commutata / Artemisia ludoviciana / Calamovilfa longifolia community occurred in a small downslope-trending depression or gully on the windward side of a dune. The dune appeared to be quite stabilized with a high vegetative cover Other graminoid species included Stipa comata, Cyperus schweinitzii, Sporobolus cryptandrus, Koeleria macrantha and Agropyron dasystachyum generally with covers of less than $1 \%$. Artemisia ludoviciana was the dominant forb with about $5 \%$ cover. An Elaeagnus commutata community has also been reported from the Foothills and Montane subregions where it forms stringers on stream terraces. Common associated species include Salix spp., Amelanchier alnifolia and Prunus virginiana (Allen 2003). 
Table 17. Similarity rating Elaeagnus commutata - Prunus virginiana / Carex siccata Koeleria macrantha community types documented within Alberta.

\begin{tabular}{|l|c|l|}
\hline \multicolumn{1}{|c|}{$\begin{array}{c}\text { Similar Communities and } \\
\text { Citations }\end{array}$} & $\begin{array}{c}\text { Similarity } \\
\text { Rating }\end{array}$ & \multicolumn{1}{c|}{ Comments } \\
\hline $\begin{array}{l}\text { Elaeagnus commutata/ Symphoricarpos } \\
\text { occidentalis - Rosa woodsii / Poa } \\
\text { palustris (Wheatley and Bentz 2002; } \\
\text { Fehr 1984) }\end{array}$ & 2 & $\begin{array}{l}\text { While site characteristics are quite similar, the species composition } \\
\text { and structure seems somewhat different than those found in this field } \\
\text { survey. Fehr only sampled 1 site in the community type however. }\end{array}$ \\
\hline $\begin{array}{l}\text { Elaeagnus commutata (Meijer and } \\
\text { Karpuk 1999; Fehr 1982; Bradley and } \\
\text { Bradley 1972) }\end{array}$ & 2 & $\begin{array}{l}\text { The species composition and site characteristics of this community are } \\
\text { quite different than those observed in the Wainwright Dunes } \\
\text { Ecological Reserve. }\end{array}$ \\
\hline $\begin{array}{l}\text { Elaeagnus commutata / Stipa comata } \\
\text { (Adams et al. 1997) }\end{array}$ & $?$ & $\begin{array}{l}\text { There is no information provided regarding the floristic composition } \\
\text { and site characteristics of this community as it is considered to be } \\
\text { minor or indistinct community that will be further developed with } \\
\text { additional field sampling. As such it is difficult to assess its similarity to } \\
\text { the community found in Wainwright. }\end{array}$ \\
\hline $\begin{array}{l}\text { Elaeagnus commutata / Artemisia } \\
\text { ludoviciana Calamovilfa longifolia } \\
\text { (Coenen and Bentz 2003; Komex 1993) }\end{array}$ & 2 & $\begin{array}{l}\text { This community is somewhat floristically different with slightly different } \\
\text { site characteristics than that observed at Wainwright. }\end{array}$ \\
\hline $\begin{array}{l}\text { Elaeagnus commutata / Glycyrrhiza } \\
\text { lepidota (Coenen and Bentz 2003) }\end{array}$ & 2 & $\begin{array}{l}\text { This community is somewhat floristically different with slightly different } \\
\text { site characteristics than that observed at Wainwright. }\end{array}$ \\
\hline Elaeagnus commutata (Allen 2003) & 3 & $\begin{array}{l}\text { This community is quite different in site characteristics and species } \\
\text { composition than that found in Wainwright. }\end{array}$ \\
\hline
\end{tabular}

Outside of Alberta, there are numerous reports of Elaeagnus commutata dominated communities and these are listed in Table 18. An Elaeagnus commutata - Rosa woodsii - Symphoricarpos occidentalis - Prunus virginiana community is described from the Great Sandhills in Saskatchewan where it occurs in low areas between dunes and also on stabilized slip faces, typically north-facing (Epp and Townley-Smith 1980). Shrub composition varied location to location and each shrub species may be dominant at specific sites, where at others may be co-dominant. Coupland (1950) described a Rosa woodsii (Artemisia cana / Elaeagnus commutata) community from the Canadian Prairie provinces. This community occurred in undulating to gently rolling areas between stabilized dunes where the water table was typically within 8 to 12 feet of the soil surface. Looman (1983) also described an Alliance Elaeagnion commtatae that community was described from the Canadian Prairie Provinces, where it was found on sandy or stony soils. Associated species included Rosa acicularis, Prunus virginiana, and Ribes oxyacanthoides.

An Elaeagnus commutata / Pascopyrum smithii community is described in Manitoba, Montana, North Dakota and Saskatchewan (NatureServe 2003; MNHP 2002; Schneider et al. 1997). This community occurred on a variety of glacial landforms including kames, eskers and areas of till and outwash. It was commonly found on north-facing slopes and sites where moisture was more abundant, including along river valley slopes. The vegetation formed open thickets within the mixed-grass prairie landscape. Elaeagnus commutata was generally a short to medium height shrub. Pascopyrum smithii was not a dominant species at Wainwright, so it floristically different. An Elaeagnus commutata community is documented from northern Montana, east of Continental divide (MNHP 2002; Heidel et al. 2000). This community was classified as temporarily flooded, hence it is not thought to be similar to the community found in the Wainwright Dunes Ecological Reserve. In the Medicine Lake sandhills in Montana, sites had shrub cover of $10 \%$ and grass cover of $70 \%$. NatureServe (2003) also reported an Elaeagnus commutata community from the northern Great Plains in a mixedgrass prairie matrix. It was dominated by mid to tall shrubs, especially Elaeagnus commutata. Pascopyrum smithii was dominant in the herbaceous layer, typically accompanied by Koeleria macrantha, 
Schizachyrium scoparium and Hesperostipa comata. Elaeagnus commutata was noted to be most abundant on flat sandy sites in southern Saskatchewan.

Table 18. Similarity rating for Elaeagnus commutata - Prunus virginiana / Carex siccata Koeleria macrantha community types documented outside Alberta.

\begin{tabular}{|l|c|l|}
\hline \multicolumn{1}{|c|}{$\begin{array}{c}\text { Similar Communities and } \\
\text { Citations }\end{array}$} & $\begin{array}{c}\text { Similarity } \\
\text { Rating }\end{array}$ & Comments \\
\hline $\begin{array}{l}\text { Elaeagnus commutata - Rosa woodsii - } \\
\text { Symphoricarpos occidentalis - Prunus } \\
\text { virginiana (Epp and Townley-Smith 1980) }\end{array}$ & 2 & $\begin{array}{l}\text { The floristic composition and site conditions are quite different than that } \\
\text { observed at Wainwright. }\end{array}$ \\
\hline $\begin{array}{l}\text { Rosa woodsii (Artemisia cana / Elaeagnus } \\
\text { commutata) (Coupland 1950) }\end{array}$ & 2 & $\begin{array}{l}\text { Species composition different, though quite general, than that found at } \\
\text { Wainwright dunes region, but site conditions quite similar. }\end{array}$ \\
\hline $\begin{array}{l}\text { Alliance Elaeagnion commutatae (Looman } \\
\text { 1983) }\end{array}$ & 2 & $\begin{array}{l}\text { Species composition different, though quite general, than that found at } \\
\text { Wainwright dunes region, but site conditions quite similar. }\end{array}$ \\
\hline $\begin{array}{l}\text { Elaeagnus commutata / Pascopyrum } \\
\text { smithii (Schneider et al. 1997) }\end{array}$ & $?(3)$ & $\begin{array}{l}\text { No description provided, although it's noted to occur in Manitoba, } \\
\text { Montana, North Dakota and Saskatchewan. The authors suggest a } \\
\text { conservation rating of G2. No description of community type is given, } \\
\text { thus cannot assess similarity. }\end{array}$ \\
\hline $\begin{array}{l}\text { Elaeagnus commutata / Pascopyrum } \\
\text { smithii Shrubland (NatureServe 2003; } \\
\text { MNHP 2002) }\end{array}$ & 3 & $\begin{array}{l}\text { Pascopyrum smithii not a dominant species at Wainwright. Although } \\
\text { substrates described in this report are coarse, they are different than } \\
\text { eolian landforms. }\end{array}$ \\
\hline $\begin{array}{l}\text { Elaeagnus commutata Shrubland Alliance } \\
\text { (NatureServe 2003; MNHP 2002; Heidel et } \\
\text { al. 2000) }\end{array}$ & 2 & $\begin{array}{l}\text { Site conditions, being somewhat more level with a sandy substrate, are } \\
\text { similar. However the community is described here as temporarily } \\
\text { flooded, whereas Wainwright not likely experiencing flooding. }\end{array}$ \\
\hline
\end{tabular}

\subsubsection{Preliminary Conservation Ranking of Elaeagnus commutata - Prunus virginiana / Carex siccata - Koeleria macrantha Community}

Preliminary Rank: S2?

A survey of Dillberry Lake Provincial Park reported a related, though not entirely similar Elaeagnus commutata dominated community type (Meijer and Karpuk 1999), which has been assigned a preliminary conservation ranking of S2 (Wheatley and Bentz 2002). While the community found in the Wainwright Ecological Reserve does differ somewhat in the floristic composition and the site conditions, it is still not a common, widespread community type. This community occurs as small patches, typically scattered at wideranging intervals across the landscape. As such, a preliminary rank of $\mathbf{S 2}$ ? is suggested for this community type and additional sampling both within the Wainwright Dunes Ecological Reserve and other sand dune and sand plain habitats could help to careful the status of this community type. 


\subsection{Juniperus horizontalis / Stipa comata - Carex siccata Association}

Creeping juniper / needle-and-thread - hay sedge

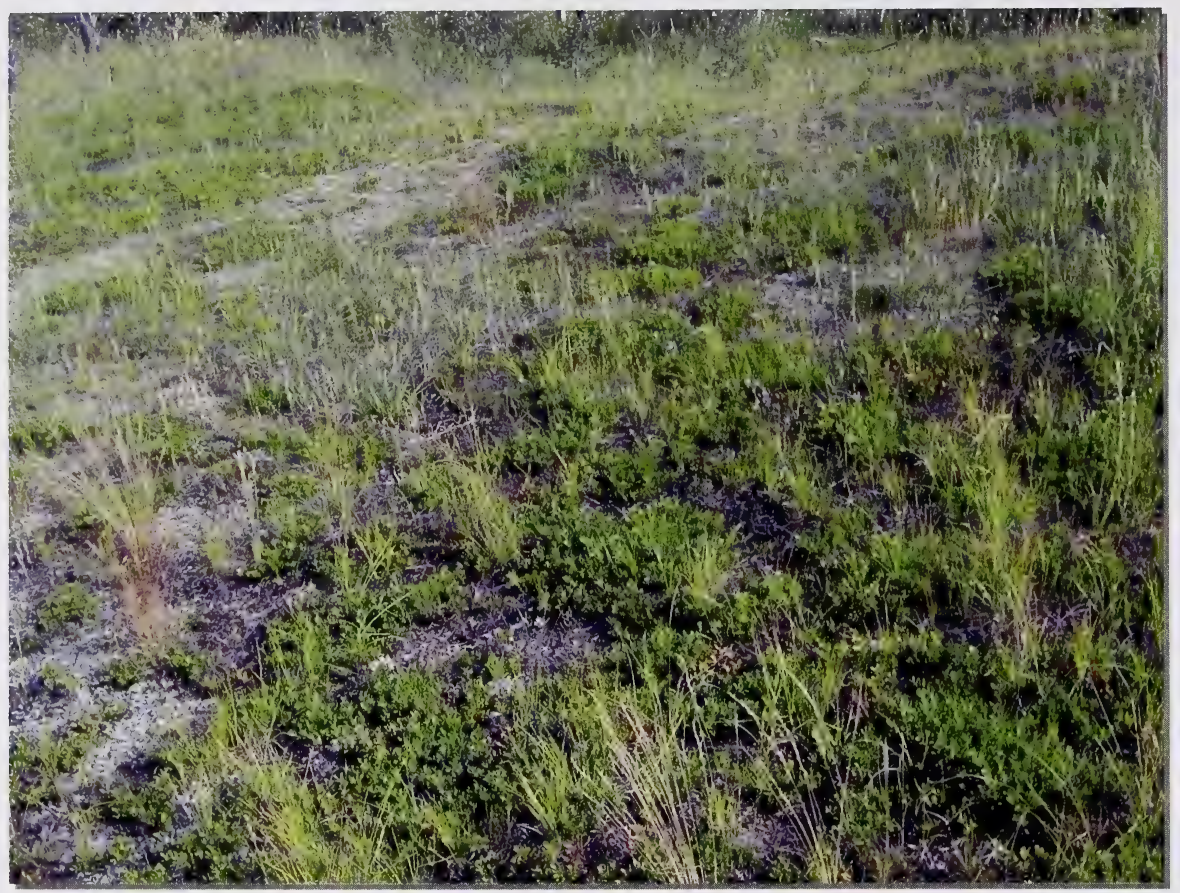

Plate 4. Juniperus horizontalis / Stipa comata - Carex siccata community type (Creeping juniper / needle-and-thread - hay sedge) Plot 38.

This community is widespread and extensive, and is dominated by Juniperus horizontalis in the low-shrub stratum, with Stipa comata and Carex siccata codominating the graminoid stratum. Combined, $S$. comata and $C$. siccata typically provide greater than $30 \%$ cover. Calamovilfa longifolia, Koeleria macrantha, and Festuca saximontana were also present at the majority of sites sampled, but with lesser prominence. Other common species, with lower coverages include Prunus virginiana, Selaginella densa, Cladina mitis, Artemisia frigida, Solidago missouriensis and Chenopodium pratericola. Table 19 summarizes the species composition, mean percent cover, standard error and species prominence for this community type. 
Table 19. Summary statistics for the Juniperus horizontalis / Stipa comata - Carex siccata community type $(n=6)$.

\begin{tabular}{|c|c|c|c|c|}
\hline Species & $\begin{array}{l}\text { Mean \% } \\
\text { Cover }\end{array}$ & $\begin{array}{l}\text { Standard } \\
\text { Error }\end{array}$ & Presence & Prominence \\
\hline $\begin{array}{l}\text { Juniperus } \\
\text { horizontalis }\end{array}$ & 17.0 & 3.0 & 6 & 15.5 \\
\hline Stipa comata & 16.8 & 3.7 & 6 & 15.3 \\
\hline Carex siccata & 15.0 & 1.7 & 6 & 13.7 \\
\hline $\begin{array}{l}\text { Arctostaphylos uva- } \\
\text { ursi }\end{array}$ & 7.0 & 4.9 & 2 & 11.1 \\
\hline $\begin{array}{l}\text { Calamovilfa } \\
\text { longifolia }\end{array}$ & 9.4 & 1.0 & 6 & 8.6 \\
\hline Koeleria macrantha & 8.8 & 1.6 & 6 & 8.0 \\
\hline Cladina mitis & 8.0 & 1.7 & 6 & 7.3 \\
\hline Selaginella densa & 7.0 & 1.6 & 5 & 7.0 \\
\hline Artemisia frigida & 5.6 & 1.6 & 5 & 5.6 \\
\hline Prunus virginiana & 4.0 & 1.4 & 5 & 4.0 \\
\hline Stipa spartea & 2.5 & 1.3 & 3 & 3.2 \\
\hline $\begin{array}{l}\text { Festuca } \\
\text { saximontana }\end{array}$ & 2.5 & 0.7 & 5 & 2.5 \\
\hline $\begin{array}{l}\text { Solidago } \\
\text { missouriensis }\end{array}$ & 2.0 & 0.8 & 4 & 2.2 \\
\hline Spirea alba & 1.0 & 0.8 & 1 & 2.2 \\
\hline Bouteloua gracilis & 1.4 & 0.8 & 2 & 2.2 \\
\hline Heliotrichon hookeri & 1.4 & 0.8 & 2 & 2.2 \\
\hline Solidago spathulata & 1.2 & 0.8 & 2 & 1.9 \\
\hline $\begin{array}{l}\text { Thermopsis } \\
\text { rhombifolia }\end{array}$ & 1.4 & 0.7 & 3 & 1.8 \\
\hline Heterotheca villosa & 1.6 & 0.4 & 4 & 1.8 \\
\hline $\begin{array}{l}\text { Artemisia } \\
\text { ludoviciana }\end{array}$ & 1.2 & 0.5 & 3 & 1.5 \\
\hline $\begin{array}{l}\text { Chenopodium } \\
\text { pratericola }\end{array}$ & 1.4 & 0.5 & 5 & 1.4 \\
\hline Rosa arkansana & 0.9 & 0.3 & 4 & 1.0 \\
\hline Carex filifolia & 0.6 & 0.3 & 2 & 0.9 \\
\hline
\end{tabular}

\begin{tabular}{|c|c|c|c|c|}
\hline Species & $\begin{array}{c}\text { Mean } \% \\
\text { Cover }\end{array}$ & $\begin{array}{l}\text { Standard } \\
\text { Error }\end{array}$ & Presence & Prominence \\
\hline Cladonia uncialis & 0.5 & 0.3 & 2 & 0.8 \\
\hline $\begin{array}{l}\text { Equisetum } \\
\text { hymenale }\end{array}$ & 0.4 & 0.2 & 3 & 0.5 \\
\hline Gaillardia aristata & 0.4 & 0.2 & 3 & 0.5 \\
\hline $\begin{array}{l}\text { Populus } \\
\text { tremuloides }\end{array}$ & 0.4 & 0.2 & 3 & 0.5 \\
\hline Erysimum asperum & 0.5 & 0.1 & 5 & 0.5 \\
\hline Festuca hallii & 0.3 & 0.2 & 2 & 0.5 \\
\hline $\begin{array}{l}\text { Agropyron } \\
\text { dasystachyum }\end{array}$ & 0.2 & 0.2 & 1 & 0.4 \\
\hline Juncus balticus & 0.2 & 0.2 & 1 & 0.4 \\
\hline Opuntia fragilis & 0.2 & 0.2 & 1 & 0.4 \\
\hline Anemone patens & 0.2 & 0.1 & 2 & 0.3 \\
\hline $\begin{array}{l}\text { Artemisia } \\
\text { campestris }\end{array}$ & 0.2 & 0.1 & 2 & 0.3 \\
\hline $\begin{array}{l}\text { Chenopodium } \\
\text { leptophyllum }\end{array}$ & 0.2 & 0.1 & 2 & 0.3 \\
\hline Agoseris glauca & 0.1 & 0.1 & 1 & 0.2 \\
\hline Arabis holboellii & 0.1 & 0.1 & 1 & 0.2 \\
\hline $\begin{array}{l}\text { Chenopodium } \\
\text { album }\end{array}$ & 0.1 & 0.1 & 1 & 0.2 \\
\hline Gallium boreale & 0.1 & 0.1 & 1 & 0.2 \\
\hline Gaura coccinea & 0.1 & 0.1 & 1 & 0.2 \\
\hline Helianthus annuus & 0.1 & 0.1 & 1 & 0.2 \\
\hline Kochia scoparia & 0.1 & 0.1 & 1 & 0.2 \\
\hline $\begin{array}{l}\text { Lepidium } \\
\text { densiflorum }\end{array}$ & 0.1 & 0.1 & 1 & 0.2 \\
\hline Poa interior & 0.1 & 0.1 & 1 & 0.2 \\
\hline Potentilla hippiana & 0.1 & 0.1 & 1 & 0.2 \\
\hline Silene drummondii & 0.1 & 0.1 & 1 & 0.2 \\
\hline Viola adunca & 0.1 & 0.1 & 1 & 0.2 \\
\hline
\end{tabular}

The Juniperus horizontalis / Stipa comata - Carex siccata community was typically found on level to gentle slopes that were at least well drained and subxeric. The soil surface typically had a shallow organic matter accumulation, although small patches of exposed soils were occasionally present. A summary of site data is provided in Table 20.

Table 20. Summary of site data for the Juniperus horizontalis / Stipa comata - Carex siccata community type $(n=6)$.

\begin{tabular}{cccccccccc}
\hline Plot Elevation & Slope & Aspect & Drainage Site Position & $\begin{array}{c}\text { Surface } \\
\text { Shape }\end{array}$ & $\begin{array}{c}\text { Moisture } \\
\text { Regime }\end{array}$ & $\begin{array}{c}\text { Nutrient } \\
\text { Regime }\end{array}$ \\
\hline 7 & 688 & 0 & n/a & Rapidly & Upper Slope & Convex & Subxeric & Poor \\
\hline 15 & 695 & 5 & 125 & Well & Middle Slope & Straight & Subxeric & Medium \\
\hline 22 & 670 & 3 & 348 & Well & Middle Slope & Straight & Subxeric & Poor \\
\hline 26 & 683 & 0 & n/a & Well & Crest & Convex & Subxeric & Medium \\
\hline 32 & 700 & 13 & 230 & Well & Lower Slope & Straight & Subxeric & Medium \\
\hline 38 & 668 & 16 & 291 & Well & Middle Slope & Concave & Subxeric & Poor \\
\hline \hline
\end{tabular}




\subsubsection{Comparison of Juniperus horizontalis / Stipa comata - Carex siccata Community to Literature}

A number of communities related to the Juniperus horizontalis / Stipa comata - Carex siccata community have been identified in Alberta and are listed in Table 21. A Juniperus horizontalis community was found in the Central Parkland in Dillberry Lake Provincial Park. At this location it occurred on steep, northeast and south facing slopes that were well drained. The parent materials included glaciofluvial and eolian deposits. Associated forbs and grasses included Heterotheca villosa, Thermopsis rhombifolia, Comandra umbellata, Stipa curtiseta, Stipa comata and Agropyron trachycaulum (Meijer and Karpuk 1999). A Juniperus horizontalis - Selaginella densa - Calamovilfa longifolia community was documented from the Wainwright Dunes Ecological Reserve, on dry outwash plains, dune complexes and kame moraines (Pearson Timberline 1993). It was described on sites that varied in aspect and slope, although all were rapidly drained with xeric to subxeric moisture regimes. Other low shrubs were occasionally present, including Rosa spp. and Prunus virginiana, while Artemisia frigida and Festuca hallii could also be present. A Juniperus horizontalis / (Koeleria macrantha) / Cladina mitis community was found in a prior survey of the Wainwright Dunes Ecological Reserve (Fehr 1984). It was generally found on stable blowout areas of sand dunes that had a xeric to very xeric moisture regime and a southerly aspect. Other lichens were noted to also occur in this community. This community is quite similar to that found during the 2003 survey of the Wainwright Dunes Ecological Reserve in terms of site conditions and floristic composition. However, the prominence of lichens suggests that the area sampled in 1984 was more successionally advanced than that surveyed in 2003.

Table 21. Similarity rating for Juniperus horizontalis / Stipa comata - Carex siccata community types documented within Alberta.

\begin{tabular}{|l|c|l|}
\hline \multicolumn{1}{|c|}{$\begin{array}{c}\text { Similar Communities and } \\
\text { Citations }\end{array}$} & $\begin{array}{c}\text { Similarity } \\
\text { Rating }\end{array}$ \\
\hline $\begin{array}{l}\text { Juniperus horizontalis (Meijer and Karpuk } \\
\text { 1999) }\end{array}$ & 2 & $\begin{array}{l}\text { This community description has different site characteristics, } \\
\text { although species composition is quite similar. }\end{array}$ \\
\hline $\begin{array}{l}\text { Juniperus horizontalis - Selaginella densa - } \\
\text { Calamovilfa longifolia (Pearson Timberline } \\
\text { 1993) }\end{array}$ & 2 & $\begin{array}{l}\text { This community description has more variable site characteristics } \\
\text { and a different species composition than what was observed in 2003. }\end{array}$ \\
\hline $\begin{array}{l}\text { Juniperus horizontalis / (Koeleria macrantha) } \\
\text { /Cladina mitis (Wheatley and Bentz 2002; } \\
\text { Fehr 1984) }\end{array}$ & 2 & $\begin{array}{l}\text { While the site characteristics between the two communities are quite } \\
\text { similar, some of the species and the prominence of these species } \\
\text { are different. }\end{array}$ \\
\hline
\end{tabular}

Outside of Alberta, there are numerous reports of Juniperus horizontalis-dominated communities and they are listed in Table 22. Hulett et al. (1966) documented two similar community types and these included (1) Juniperus horizontalis / Carex heliophila Selaginella densa community in stabilized blowouts and (2) a Juniperus horizontalis Symphoricarpos occidentalis - Populus tremuloides / Carex heliophila - Agropyron spp. - Stipa comata in the Dundurn and Great Sandhills in Saskatchewan. Stipa comata is noted to be present in the first community type, although it was not a dominant species. Hulett noted that the second community type had $84 \%$ cover of Juniperus horizontalis on average, with Populus tremuloides occurring in small groves. Looman (1983) noted Juniperus horizontalis communities described from the Canadian Prairie Provinces where it occurred on east-trending slopes. Looman noted that the juniper provided a ground cover of $70-80 \%$ but it was not a common community. There was little description provided as to the species composition of this community. 
Table 22. Similarity rating for Juniperus horizontalis / Stipa comata - Carex siccata community types documented outside Alberta.

\begin{tabular}{|c|c|c|}
\hline Similar Communities and Citations & $\begin{array}{l}\text { Similarity } \\
\text { Rating }\end{array}$ & Comments \\
\hline $\begin{array}{l}\text { Juniperus horizontalis / Carex heliophila - } \\
\text { Selaginella densa (Hulett et al. 1966) }\end{array}$ & 2 & $\begin{array}{l}\text { This community shares some floristic similarities with the } \\
\text { Wainwright community but the site characteristics are quite } \\
\text { different. }\end{array}$ \\
\hline $\begin{array}{l}\text { Juniperus horizontalis - Symphoricarpos } \\
\text { occidentalis - Populus tremuloides / Carex } \\
\text { heliophila - Agropyron spp. - Stipa comata } \\
\text { (Hulett et al. 1966) }\end{array}$ & 1 & $\begin{array}{l}\text { This community shares many floristic similarities with the } \\
\text { Wainwright community and quite similar site conditions. }\end{array}$ \\
\hline $\begin{array}{l}\text { Juniperus horizontalis communities (Looman } \\
\text { 1983) }\end{array}$ & 2 & $\begin{array}{l}\text { There is little description provided as to the species } \\
\text { composition of this community, and there are some differences } \\
\text { in the site conditions. }\end{array}$ \\
\hline $\begin{array}{l}\text { Juniperus horizontalis / Carex inops ssp. } \\
\text { heliophila Dwarf-shrubland (NatureServe 2003; } \\
\text { MNHP 2002;Faber-Langendoen 2001; } \\
\text { Schneider et al. 1997) }\end{array}$ & 2 & $\begin{array}{l}\text { This community shares some floristic similarities although the } \\
\text { site characteristics are quite different. }\end{array}$ \\
\hline $\begin{array}{l}\text { Juniperus horizontalis / Carex heliophila } \\
\text { (Hansen and Hoffman 1988) }\end{array}$ & 3 & $\begin{array}{l}\text { This community shares some floristic similarities although the } \\
\text { site characteristics are quite different. }\end{array}$ \\
\hline $\begin{array}{l}\text { Juniperus horizontalis / Schizachyrium } \\
\text { scoparium Dwarf-shrubland (Faber-Langendoen } \\
\text { 2001; Marriott and Faber-Langendoen 2000; } \\
\text { Schneider et al. 1997) }\end{array}$ & 2 & $\begin{array}{l}\text { This community shares some floristic similarities although the } \\
\text { site characteristics are quite different. }\end{array}$ \\
\hline $\begin{array}{l}\text { Juniperus horizontalis - Arctostaphylos uva-ursi - } \\
\text { Juniperus communis Dune Dwarf-shrubland } \\
\text { (NatureServe 2003; Faber-Langendoen 2001) }\end{array}$ & 3 & $\begin{array}{l}\text { This community, while sharing some floristic similarities, has } \\
\text { different site conditions than that observed in Wainwright. }\end{array}$ \\
\hline
\end{tabular}

In the northwestern Great Plains of the United States, several authors documented a Juniperus horizontalis / Carex inops ssp. heliophila community ranging from southeastern Montana to South Dakota (NatureServe 2003; MNHP 2002; FaberLangendoen 2001; Schneider et al. 1997). This community type was typically found on moderate to steep (35-80\%) north-facing slopes, on sandy loam soils. This community was dominated Juniperus horizontalis although other species, such as Artemisia frigida and Symphoricarpos occidentalis were present though not abundant. Grasses and sedges were abundant, particularly Carex inops ssp. heliophila, although Schizachyrium scoparium, Carex filifolia, Koeleria macrantha and Elymus lanceolatus were also present. Common forbs included Campanula rotundifolia, Thermopsis rhombifolia, Anemone patens, Galium boreale and Dalea purpurea (Faber-Langendoen 2001; Schneider et al. 1997). Also, Hansen and Hoffman (1988) described a Juniperus horizontalis / Carex heliophila community type is documented from the Custer National Forest in Montana and South Dakota, where it occurred on steep, north-facing slopes. Other than the dominant species, Andropogon scoparius, Carex filifolia, Thermopsis rhombifolia, Koeleria macrantha, Agropyron dasystachyum, Anemone patens and Petalostemon purpureum were common species. This community was typically found on sandy loams.

Several authors noted a Juniperus horizontalis / Schizachyrium scoparium dwarfshrubland community type is described from the northwestern Great Plains in Canada and the U.S. ranging from Montana and South Dakota to North Dakota and southern Manitoba (Faber-Langendoen 2001; Marriott and Faber-Langendoen 2000; Schneider et al. 1997). This community typically occurred on moderate to steep slopes, usually in an upper slope position. Generally this community had a north to west-facing aspect although in Manitoba it was documented on dry south-facing slopes. Soils were silty loams, sandy loams, or clay loams and short shrubs and graminoids dominated this community. Juniperus horizontalis was the dominant dwarf shrub although other species including Artemisia frigida, Symphoricarpos occidentalis, Rosa arkansana, Rhus trilobata and Prunus virginiana were present. Schizachyrium scoparium was noted to be the 
dominant graminoid, although Calamovilfa longifolia, Carex filifolia, Carex inops ssp. heliophila, Carex eleocharis, Koeleria macrantha, and Muhlenbergia cuspidata were also common. Bare ground occupied $25-45 \%$ of the ground surface cover.

Several authors also noted a Juniperus horizontalis - Arctostaphylos uva-ursi Juniperus communis community from the U.S. Midwest, where it is found on flat-topped, wind-swept, stabilized dunes (NatureServe 2003; Faber-Langendoen 2001). It was found throughout the dune areas of the western Great Lakes region, of the U.S. and Canada, ranging from the shores of southern Michigan, Illinois, Indiana and Michigan, north to the shores of other Great Lakes such as Superior in Wisconsin. The community was typically an open to closed dwarf-shrub mat. Hudsonia tomentosa was also present, along with various deciduous shrubs. Ammophila breviligulata and Schizachiyrium scoparium were noted to be the dominant herbaceous species.

\subsubsection{Preliminary Conservation Ranking of Juniperus horizontalis / Stipa comata - Carex siccata Community}

Preliminary Rank: S3S4

A Juniperus horizontalis - Selaginella densa - Calamovilfa longifolia community was previously documented from the Wainwright Dunes Ecological Reserve, on dry outwash plains, dune complexes and kame moraines and was given a preliminary rank of S4 (Wheatley and Bentz 2002; Pearson Timberline 1993). It was described on sites that varied in aspect and slope, although all were rapidly drained with xeric to subxeric moisture regimes. This community shares some of the same site characteristics, however the species composition is notably different.

There have also been numerous reports documenting Juniperus horizontalis-dominated communities, as a pioneer or early successional community on bare sand. However, this community observed in the Wainwright Dunes area is well established with minimal exposed sand at the surface. While this community is likely restricted to eolian landscapes, it was found to be quite widespread through the Wainwright Dunes Ecological Reserve. As such a preliminary rank of S3S4 is suggested for this community type, although additional sampling in eolian landscapes in other areas of the province may help to clarify its full geographic extent. 


\subsection{Juniperus horizontalis / Calamovilfa longifolia - Carex pensylvanica ssp. heliophila Association}

Creeping juniper / sand grass - sun-loving sedge

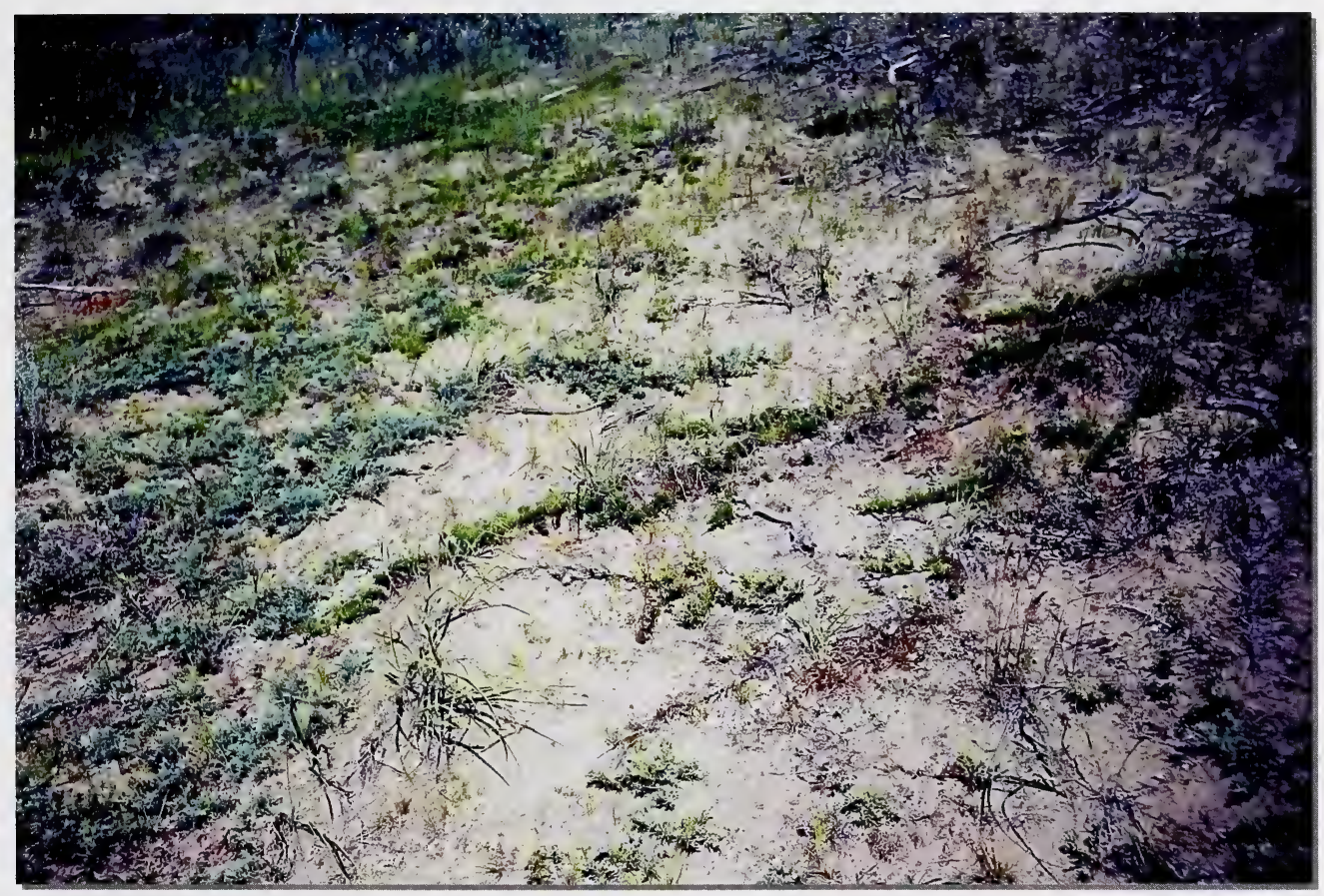

Plate 5. Juniperus horizontalis / Calamovilfa longifolia - Carex pensylvanica ssp. heliophila (Creeping juniper / sand grass - sun-loving sedge) Plot 13.

The Juniperus horizontalis / Calamovilfa longifolia - Carex pensylvanica ssp. heliophila community was very limited in extent, being found on partially stabilized dunes. Juniperus horizontalis dominates the low shrub stratum, with Calamovilfa longifolia and Carex pensylvanica ssp. heliophila co-dominating the graminoid stratum. Sporobolus cryptandrus was present in the majority of sites surveyed with a mean cover of approximately $8 \%$, however it was not found at all sites. Other common graminoids included Carex siccata, Stipa comata and Koeleria macrantha, though typically with covers less than $10 \%$. Artemisia frigida, Prunus virginiana, Cladina mitis and Heterotheca villosa were also relatively common species, though with relatively low percent covers. Table 23 summarizes the species composition, mean percent cover, standard error and species prominence for this community type. 
Table 23. Summary statistics for the Juniperus horizontalis / Calamovilfa longifolia Carex pensylvanica ssp. heliophila community type $(n=3)$.

\begin{tabular}{lcccc}
\hline \multicolumn{1}{c}{ Species } & $\begin{array}{c}\text { Mean } \% \\
\text { Cover }\end{array}$ & $\begin{array}{c}\text { Standard } \\
\text { Error }\end{array}$ & Presence & Prominence \\
\hline Calamovilfa longifolia & 19.0 & 6.7 & 3.0 & 19.0 \\
\hline $\begin{array}{l}\text { Juniperus } \\
\text { horizontalis }\end{array}$ & 17.3 & 5.4 & 3.0 & 17.3 \\
\hline $\begin{array}{l}\text { Sporobolus } \\
\text { cryptandrus }\end{array}$ & 8.3 & 6.0 & 2.0 & 10.2 \\
\hline $\begin{array}{l}\text { Carex pensylvanica } \\
\text { ssp. heliophila }\end{array}$ & 7.0 & 4.2 & 3.0 & 7.0 \\
\hline Carex siccata & 5.7 & 2.3 & 3.0 & 5.7 \\
\hline Artemisia frigida & 5.3 & 4.8 & 3.0 & 5.3 \\
\hline Stipa comata & 4.0 & 1.0 & 3.0 & 4.0 \\
\hline Koeleria macrantha & 4.0 & 1.0 & 3.0 & 4.0 \\
\hline Selaginella densa & 1.7 & 1.7 & 1.0 & 2.9 \\
\hline $\begin{array}{l}\text { Arctostaphylos uva- } \\
\text { ursi }\end{array}$ & 1.7 & 1.7 & 1.0 & 2.9 \\
\hline $\begin{array}{l}\text { Prunus virginiana } \\
\text { Cladina mitis }\end{array}$ & 2.5 & 0.9 & 3.0 & 2.5 \\
\hline $\begin{array}{l}\text { Chamaerhodos } \\
\text { erecta }\end{array}$ & 2.3 & 0.3 & 3.0 & 2.3 \\
\hline Solidago spathulata & 0.7 & 0.7 & 1.0 & 1.2 \\
\hline
\end{tabular}

\begin{tabular}{lcccc}
\hline Species & $\begin{array}{c}\text { Mean } \% \\
\text { Cover }\end{array}$ & $\begin{array}{c}\text { Standard } \\
\text { Error }\end{array}$ & Presence Prominence \\
$\begin{array}{l}\text { Chenopodium } \\
\text { pratericola }\end{array}$ & 0.7 & 0.7 & 1.0 & 1.2 \\
\hline Carex filifolia & 1.0 & 0.6 & 2.0 & 1.2 \\
\hline $\begin{array}{l}\text { Populus tremuloides } \\
\text { Heterotheca villosa }\end{array}$ & 0.8 & 0.4 & 2.0 & 1.0 \\
\hline Rosa arkansana & 0.5 & 0.0 & 3.0 & 1.0 \\
\hline Kochia scoparia & 0.3 & 0.3 & 2.0 & 0.6 \\
\hline Festuca saximontana & 0.5 & 0.3 & 1.0 & 0.6 \\
\hline Cladonia uncialis & 0.3 & 0.3 & 1.0 & 0.6 \\
\hline $\begin{array}{l}\text { Chenopodium } \\
\text { leptophyllum }\end{array}$ & 0.3 & 0.2 & 2.0 & 0.4 \\
\hline $\begin{array}{l}\text { Thermopsis } \\
\text { rhombifolia }\end{array}$ & 0.2 & 0.2 & 1.0 & 0.3 \\
\hline Erysimum asperum & 0.2 & 0.2 & 1.0 & 0.3 \\
\hline Equisetum hymenale & 0.2 & 0.2 & 1.0 & 0.3 \\
\hline Descurainia sophia & 0.2 & 0.2 & 1.0 & 0.3 \\
\hline Artemisia ludoviciana & 0.2 & 0.2 & 1.0 & 0.3 \\
\hline Artemisia campestris & 0.2 & 0.2 & 1.0 & 0.3 \\
\hline & & & & \\
\hline
\end{tabular}

When present, this community was found on strong south to southwest facing dune slopes, where some active sand movement was present. All sites had between $20-35 \%$ exposed sand, with the remainder having organic matter or vegetative cover. This subxeric community was typically in a mid-slope position with a straight to convex surface shape. A summary of site data is provided in Table 24.

Table 24. Summary of site data for the Juniperus horizontalis / Calamovilfa longifolia Carex pensylvanica ssp. heliophila community type $(n=3)$.

\begin{tabular}{ccccccccc}
\hline Plot Elevation & Slope & Aspect & Drainage Site Position & $\begin{array}{c}\text { Surface } \\
\text { Shape }\end{array}$ & $\begin{array}{l}\text { Moisture } \\
\text { Regime }\end{array}$ & $\begin{array}{c}\text { Nutrient } \\
\text { Regime }\end{array}$ \\
\hline 13 & 688 & 38 & 243 & Rapidly & Middle Slope & Straight & Subxeric & Poor \\
\hline 14 & 697 & 32 & 186 & Rapidly & Middle Slope & Convex & Subxeric & Poor \\
\hline 16 & 670 & 22 & 225 & Rapidly & Middle Slope & Straight & Subxeric & Poor \\
\hline \hline
\end{tabular}

\subsubsection{Comparison of Juniperus horizontalis / Calamovilfa longifolia - Carex pensylvanica ssp. heliophila Community to Literature}

Previous studies in the Wainwright Dunes Ecological Reserve and elsewhere in Alberta have identified related community types and these are noted in Table 25. Fehr (1984) described a "stabilized blowout" community type from the Wainwright Dunes Ecological Reserve Canopy. In this community, the cover of the herb-dwarf shrub layer in more stable blowout sites averaged $45 \%$, ranging from $30-60 \%$. Mineral soil cover was approximately $40 \%$. Most plants found were important colonizers of bare sand, including Carex foenea, Calamovilfa Iongifolia, Elymus canadensis, Oryzopsis hymenoides, Festuca saximontana, and Chrysopsis villosa. Selaginella densa, Carex obtusata, 
Koeleria cristata and Juniper horizontalis were important species in more stable blowouts. Similarly, a Juniperus horizontalis - Selaginella densa - Calamovilfa longifolia community was documented from the Wainwright Dunes Ecological Reserve, on dry outwash plains, dune complexes and kame moraines (Pearson Timberline 1993). It was described on sites that varied in aspect and slope, although all were rapidly drained with xeric to subxeric moisture regimes. Other shorter shrubs were occasionally present, including Rosa spp. and Prunus virginiana, while Artemisia frigida and Festuca hallii could also be present. A Juniperus horizontalis / (Koeleria macrantha) / Cladina mitis community was found in a prior survey of the Wainwright Dunes Ecological Reserve. It was generally found on stable blowout areas of sand dunes that had a xeric to very xeric moisture regime and a southerly aspect. Other lichens were noted to also occur in this community. A Juniperus horizontalis community was also found in the Central Parkland in Dillberry Lake Provincial Park. At this location it occurred on steep, northeast and south facing slopes that were well drained. The parent materials included glaciofluvial and eolian deposits. Associated forbs and grasses included Heterotheca villosa, Thermopsis rhombifolia, Comandra umbellata, Stipa curtiseta, Stipa comata and Agropyron trachycaulum. (Meijer and Karpuk 1999).

Table 25. Similarity rating for Juniperus horizontalis / Calamovilfa longifolia - Carex pensylvanica ssp. heliophila community types documented within Alberta.

\begin{tabular}{|l|c|l|}
\hline Similar Communities and Citations & $\begin{array}{c}\text { Similarity } \\
\text { Rating }\end{array}$ \\
\hline Stabilized blowout (Fehr 1984) & 1 & $\begin{array}{l}\text { This community description fits with the observed site } \\
\text { characteristics with few differences in species composition. }\end{array}$ \\
\hline $\begin{array}{l}\text { Juniperus horizontalis - Selaginella densa - } \\
\text { Calamovilfa longifolia (Pearson Timberline 1993) }\end{array}$ & 2 & $\begin{array}{l}\text { This community description has more variable site } \\
\text { characteristics and a different species composition than what } \\
\text { was observed in 2003. }\end{array}$ \\
\hline $\begin{array}{l}\text { Juniperus horizontalis /(Koeleria macrantha) / } \\
\text { Cladina mitis (Allen 2003; Wheatley and Bentz } \\
\text { 2002; Fehr 1984) }\end{array}$ & 1 & $\begin{array}{l}\text { While some of the species are different between these two } \\
\text { communities, the site characteristics between the two are quite } \\
\text { similar and likely represent the same community. }\end{array}$ \\
\hline Juniperus horizontalis (Meijer and Karpuk 1999) & 2 & $\begin{array}{l}\text { This community describes similar site characteristics, but the } \\
\text { species composition slightly different. }\end{array}$ \\
\hline
\end{tabular}

Outside Alberta a number of related community types have been documented and these are listed in Table 26. Hulett et al. (1966) documented two similar community types and these included (1) Juniperus horizontalis / Carex heliophila - Selaginella densa community in stabilized blowouts and (2) a Juniperus horizontalis - Symphoricarpos occidentalis - Populus tremuloides / Carex heliophila - Agropyron spp. - Stipa comata in the Dundurn and Great Sandhills in Saskatchewan. Stipa comata is noted to be present in the first community type, although it was not a dominant species. Hulett noted that the second community type had $84 \%$ cover of Juniperus horizontalis on average, with Populus tremuloides occurring in small groves. Looman (1983) noted Juniperus horizontalis communities described from the Canadian Prairie Provinces where it occurred on east-trending slopes. Looman noted that the juniper provided a ground cover of $70-80 \%$ but it was not a common community. There was little description provided as to the species composition of this community.

In the northwestern Great Plains of the United States, several authors documented a Juniperus horizontalis / Carex inops ssp. heliophila community ranging from southeastern Montana to South Dakota (NatureServe 2003; MNHP 2002; FaberLangendoen 2001; Schneider et al. 1997). This community type was typically found on moderate to steep (35-80\%) north-facing slopes, on sandy loam soils. This community was dominated Juniperus horizontalis although other species, such as Artemisia frigida and Symphoricarpos occidentalis were present though not abundant. Grasses and 
sedges were abundant, particularly Carex inops ssp. heliophila, although Schizachyrium scoparium, Carex filifolia, Koeleria macrantha and Elymus lanceolatus were also present. Common forbs included Campanula rotundifolia, Thermopsis rhombifolia, Anemone patens, Galium boreale and Dalea purpurea (Faber-Langendoen 2001; Schneider et al. 1997). Also, Hansen and Hoffman (1988) described a Juniperus horizontalis / Carex heliophila community type is documented from the Custer National Forest in Montana and South Dakota, where it occurred on steep, north-facing slopes. Other than the dominant species, Andropogon scoparius, Carex filifolia, Thermopsis rhombifolia, Koeleria macrantha, Agropyron dasystachyum, Anemone patens and Petalostemon purpureum were common species. This community was typically found on sandy loams.

Several authors noted a Juniperus horizontalis / Schizachyrium scoparium dwarfshrubland community type is described from the northwestern Great Plains in Canada and the U.S. ranging from Montana and South Dakota to North Dakota and southern Manitoba (Faber-Langendoen 2001; Marriott and Faber-Langendoen 2000; Schneider et al. 1997). This community typically occurred on moderate to steep slopes, usually in an upper slope position. Generally this community had a north to west-facing aspect although in Manitoba it was documented on dry south-facing slopes. Soils were silty loams, sandy loams, or clay loams and short shrubs and graminoids dominated this community. Juniperus horizontalis was the dominant dwarf shrub although other species including Artemisia frigida, Symphoricarpos occidentalis, Rosa arkansana, Rhus trilobata and Prunus virginiana were present. Schizachyrium scoparium was noted to be the dominant graminoid, although Calamovilfa longifolia, Carex filifolia, Carex inops ssp. heliophila, Carex eleocharis, Koeleria macrantha, and Muhlenbergia cuspidata were also common. Bare ground occupied $25-45 \%$ of the ground surface cover.

Table 26. Similarity rating for Juniperus horizontalis / Calamovilfa longifolia - Carex pensylvanica ssp. heliophila community types documented outside Alberta.

\begin{tabular}{|c|c|c|}
\hline Similar Communities and Citations & $\begin{array}{l}\text { Similarity } \\
\text { Rating }\end{array}$ & Comments \\
\hline $\begin{array}{l}\text { Juniperus horizontalis / Carex heliophila - } \\
\text { Selaginella densa (Hulett et al. 1966) }\end{array}$ & 1 & $\begin{array}{l}\text { This community was found in stabilized blowouts in the } \\
\text { Dundurn and Great Sandhills in Saskatchewan. Calamovilfa } \\
\text { longifolia is noted to be common, though not dominant, } \\
\text { species. This community shares many floristic similarities with } \\
\text { the Wainwright community and the site characteristics are quite } \\
\text { similar as well. }\end{array}$ \\
\hline $\begin{array}{l}\text { Juniperus horizontalis - Symphoricarpos } \\
\text { occidentalis - Populus tremuloides / Carex } \\
\text { heliophila - Agropyron spp. - Stipa comata } \\
\text { (Hulett et al. 1966) }\end{array}$ & 3 & $\begin{array}{l}\text { This community, while sharing some floristic similarities, has } \\
\text { different site conditions than that observed in Wainwright. }\end{array}$ \\
\hline $\begin{array}{l}\text { Juniperus horizontalis communities (Looman } \\
\text { 1983) }\end{array}$ & 2 & $\begin{array}{l}\text { There is little description provided as to the species } \\
\text { composition of this community, and there are some differences } \\
\text { in the site conditions. }\end{array}$ \\
\hline $\begin{array}{l}\text { Juniperus horizontalis / Carex inops ssp. } \\
\text { heliophila Dwarf-shrubland (NatureServe 2003; } \\
\text { MNHP 2002; Faber-Langendoen 2001; } \\
\text { Schneider et al. 1997) }\end{array}$ & 1 & $\begin{array}{l}\text { This community shares many floristic similarities although } \\
\text { some of the site characteristics are slightly different. }\end{array}$ \\
\hline $\begin{array}{l}\text { Juniperus horizontalis / Carex heliophila } \\
\text { (Hansen and Hoffman 1988) }\end{array}$ & 2 & $\begin{array}{l}\text { This community shares numerous floristic similarities although } \\
\text { the site characteristics are slightly different. }\end{array}$ \\
\hline $\begin{array}{l}\text { Juniperus horizontalis / Schizachyrium } \\
\text { scoparium Dwarf-shrubland (Faber-Langendoen } \\
\text { 2001; Marriott and Faber-Langendoen 2000; } \\
\text { Schneider et al. 1997) }\end{array}$ & 2 & $\begin{array}{l}\text { This community shares some floristic similarities but matches } \\
\text { the site characteristics documented from Wainwright. }\end{array}$ \\
\hline $\begin{array}{l}\text { Juniperus horizontalis - Arctostaphylos uva-ursi - } \\
\text { Juniperus communis Dune Dwarf-shrubland } \\
\text { (NatureServe 2003; Faber-Langendoen 2001) }\end{array}$ & 3 & $\begin{array}{l}\text { This community is similar in that it's found on sand dunes, } \\
\text { however the floristic composition is notably different. }\end{array}$ \\
\hline
\end{tabular}

A Juniperus horizontalis - Arctostaphylos uva-ursi - Juniperus communis community has been identified from the U.S. Midwest by several authors, where it is found on flat- 
topped, wind-swept, stabilized dunes (NatureServe 2003; Faber-Langendoen 2001). It was found throughout the dune areas of the western Great Lakes region, of the U.S. and Canada, ranging from the shores of southern Michigan, Illinois, Indiana and Michigan, north to the shores of other Great Lakes such as Superior in Wisconsin. The community was typically an open to closed dwarf-shrub mat. Hudsonia tomentosa was also present, along with various deciduous shrubs. Ammophila breviligulata and Schizachiyrium scoparium were noted to be the dominant herbaceous species.

\subsubsection{Preliminary Conservation Ranking of Juniperus horizontalis / Calamovilfa longifolia - Carex pensylvanica ssp. heliophila Community}

Preliminary Rank: S3?

The main limitation to the occurrence of this community is the availability and size of appropriate habitat, namely recently active sand dunes and blowouts. As such, there is a significant limitation to the expected distribution of this community type within the Central Parkland Natural Subregion. However, there is not a significant amount of information available regarding this community type. A preliminary rank of S3? is suggested for this community type and additional sampling of sand dune and sandplain habitats would be beneficial for clarifying the status and geographic extent of this community type. 


\subsection{Populus balsamifera / Corylus cornuta - Cornus stolonifera / Aralia nudicaulis Association}

Balsam poplar / beaked hazelnut - red-osier dogwood / wild sarsaparilla

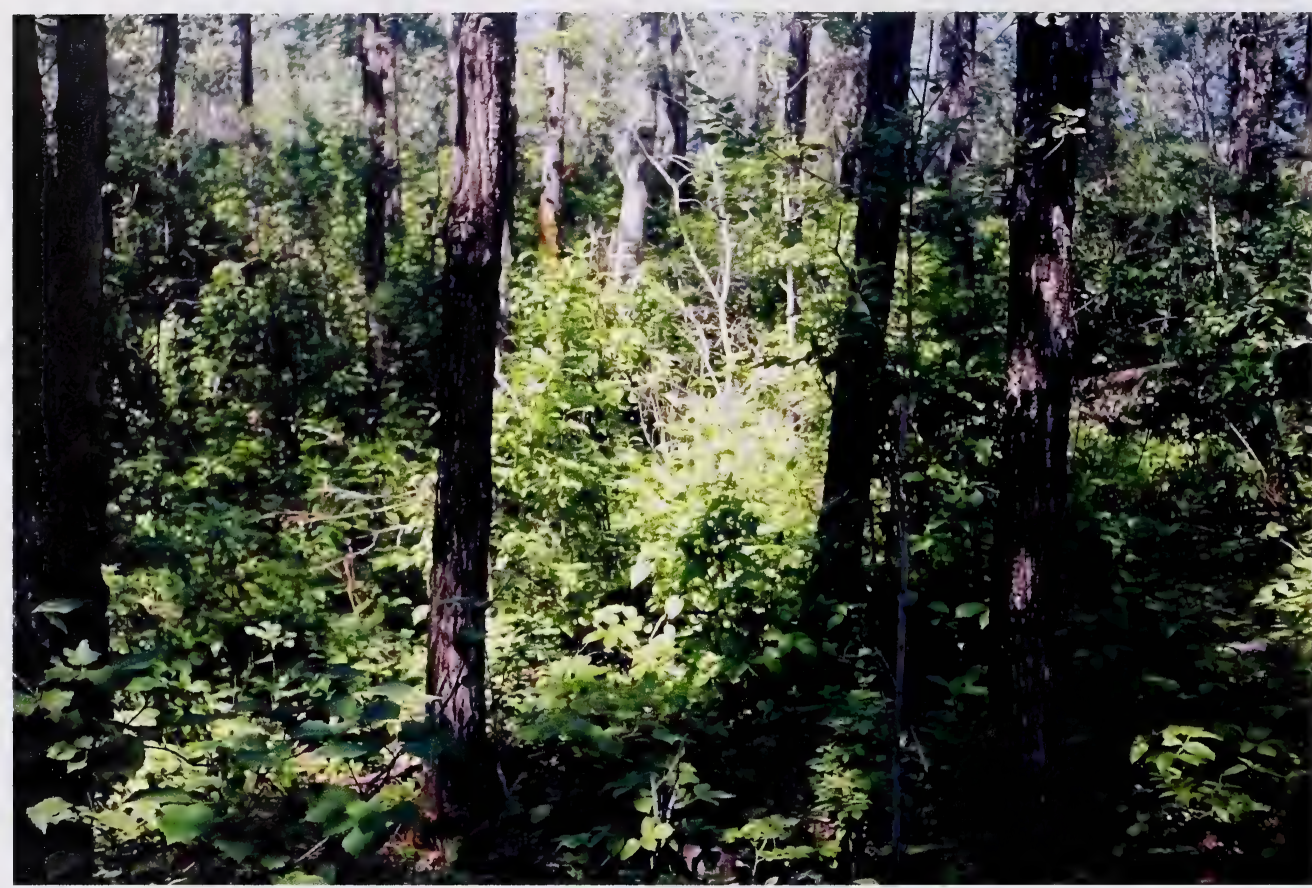

Plate 6. Populus balsamifera / Corylus cornuta - Cornus stolonifera / Aralia nudicaulis community type (Balsam poplar / beaked hazelnut - red-osier dogwood / wild sarsaparilla) Plot 4.

The Populus balsamifera / Corylus cornuta - Cornus stolonifera / Aralia nudicaulis community was quite limited in extent, occurring in lower or toe slope positions where seasonal moisture or seepage was present. Populus balsamifera dominated this community although understorey shrub cover was very high, typically exceeding $100 \%$ when combining the low, mid and tall shrub strata. Corylus cornuta was the dominant understorey shrub, with Cornus stolonifera, Viburnum opulus, Rosa acicularis, Salix bebbiana, Ribes oxyacanthoides, Symphoricarpos occidentalis and Lonicera dioica also relatively common though with lower percent coverages. Aralia nudicaulis was the dominant forb with approximately $10 \%$ cover, although Rubus pubescens, Thalictrum venulosum, Lathyrus ochroleucus, Aster ciliolatus, Smilacina stellata and Disporum trachycarpum were also present. Table 27 summarizes the species composition, mean percent cover, standard error and species prominence for this community type. 
Table 27.Summary statistics for the Populus balsamifera / Corylus cornuta - Cornus stolonifera / Aralia nudicaulis community type $(n=2)$.

\begin{tabular}{lcccc}
\hline \multicolumn{1}{c}{ Species } & $\begin{array}{c}\text { Mean } \% \\
\text { Cover }\end{array}$ & $\begin{array}{c}\text { Standard } \\
\text { Error }\end{array}$ & Presence Prominence \\
\hline Populus balsamifera & 30.3 & 5.5 & 2 & 30.3 \\
\hline Corylus cornuta & 17.3 & 9.0 & 2 & 17.3 \\
\hline Cornus stolonifera & 10.7 & 9.0 & 2 & 10.7 \\
\hline Aralia nudicaulis & 10.0 & 0.0 & 2 & 10.0 \\
\hline Viburnum opulus & 9.0 & 11.5 & 2 & 9.0 \\
\hline Rosa acicularis & 4.0 & 1.0 & 2 & 4.0 \\
\hline Salix bebbiana & 4.0 & 4.0 & 2 & 4.0 \\
\hline Populus tremuloides & 4.7 & 5.0 & 2 & 3.8 \\
\hline Ribes oxyacanthoides & 2.4 & 3.4 & 2 & 2.4 \\
\hline Rubus pubescens & 2.3 & 1.5 & 2 & 2.3 \\
\hline Thalictrum venulosum & 2.3 & 1.5 & 2 & 2.3 \\
\hline Lathyrus ochroleucus & 1.3 & 1.0 & 2 & 1.3 \\
\hline Aster ciliolatus & 1.0 & 1.4 & 2 & 1.0 \\
\hline Linnea borealis & 1.0 & 0.5 & 2 & 1.0 \\
\hline Symphoricarpos & 1.0 & 0.5 & 2 & 1.0 \\
\hline occidentalis & 0.7 & 1.0 & 1 & 0.9 \\
\hline \hline
\end{tabular}

\begin{tabular}{lcccc}
\hline \multicolumn{1}{c}{ Species } & $\begin{array}{c}\text { Mean } \% \\
\text { Cover }\end{array}$ & $\begin{array}{c}\text { Standard } \\
\text { Error }\end{array}$ & Presence Prominence \\
\hline Symphoricarpos albus & 0.7 & 1.0 & 1 & 0.9 \\
\hline Viola canadensis & 0.7 & 1.0 & 1 & 0.9 \\
\hline Shepherdia candensis & 0.9 & 1.2 & 2 & 0.9 \\
\hline Lonicera dioica & 0.8 & 0.8 & 2 & 0.8 \\
\hline Oryzopsis asperifolia & 0.7 & 0.0 & 2 & 0.7 \\
\hline Pyrola asarifolia & 0.5 & 0.3 & 2 & 0.5 \\
\hline Amelanchier alnifolia & 0.3 & 0.5 & 1 & 0.5 \\
\hline $\begin{array}{l}\text { Maianthemum } \\
\text { candense }\end{array}$ & 0.3 & 0.5 & 1 & 0.5 \\
\hline Rubus idaeus & 0.3 & 0.5 & 1 & 0.5 \\
\hline Smilacina stellata & 0.4 & 0.4 & 2 & 0.4 \\
\hline $\begin{array}{l}\text { Epilobium } \\
\text { angustifolium }\end{array}$ & 0.2 & 0.3 & 1 & 0.2 \\
\hline Gallium triflorum & 0.2 & 0.3 & 1 & 0.2 \\
\hline Ribes triste & 0.2 & 0.3 & 1 & 0.2 \\
\hline $\begin{array}{l}\text { Disporum } \\
\text { trachycarpum }\end{array}$ & 0.2 & 0.2 & 2 & 0.2 \\
\hline Sanicula marilandica & 0.2 & 0.2 & 2 & 0.2 \\
\hline Gallium boreale & 0.0 & 0.1 & 1 & 0.0 \\
\hline \hline
\end{tabular}

This community type was found on lower gentle to level slope positions, with a subhygric moisture regime and rich (permesotrophic) nutrient regime. Both sites had significant organic matter (well-humified) accumulation over a sandy, mineral substrate and decaying wood at the soil surface was typical. A summary of site data is provided in Table 28.

Table 28. Summary of site data for the Populus balsamifera / Corylus cornuta - Cornus stolonifera / Aralia nudicaulis community type $(n=2)$.

\begin{tabular}{cccccccccc}
\hline Plot Elevation & Slope & Aspect & Drainage & Site Position & $\begin{array}{c}\text { Surface } \\
\text { Shape }\end{array}$ & $\begin{array}{c}\text { Moisture } \\
\text { Regime }\end{array}$ & $\begin{array}{c}\text { Nutrient } \\
\text { Regime }\end{array}$ \\
\hline 4 & 688 & 4 & 186 & Well & Lower Slope & Concave & Subhygric & Rich \\
\hline 5 & 689 & 0 & $\mathrm{n} / \mathrm{a}$ & Well & Level & Straight & Subhygric & Rich \\
\hline \hline
\end{tabular}

\subsubsection{Comparison of Populus balsamifera / Corylus cornuta - Cornus stolonifera / Aralia nudicaulis Community to Literature}

Previous studies in the Wainwright Dunes Ecological Reserve and elsewhere in Alberta have identified related community types and these are listed in Table 29. Fehr (1984) documented a balsam poplar community type that was generally located in lower slopes or depressional site positions and had a well-developed tree layer. Balsam poplar was dominant though stands often had an aspen component. The understorey typically had two well-developed shrub layers including willow, Viburnum trilobum, Cornus stolonifera, Rosa acicularis, Symphoricarpos albus, Ribes spp. and Corylus cornuta. There was also 
a well-developed herb layer, including Aralia nudicaulis, Thalictrum venulosum, Rubus pubescens and Aster ciliolatus. Wheatley and Bentz (2002) described a Populus balsamifera / Viburnum opulus - Cornus stolonifera / Aralia nudicaulis community type from the Central Parkland subregion. This community was noted to have a consistently well-developed Populus balsamifera layer, with understorey shrub cover averaging $60 \%$. Understorey species included Cornus stolonifera, Populus tremuloides, Rosa acicularis, Symphoricarpos occidentalis, and shade tolerant species such as Aralia nudicaulis, Thalictrum venulosum, Rubus pubescens, and Aster ciliolatus.

Several balsam poplar community types have been described from the Boreal Mixedwood (Dry and Central Mixedwood) and Foothills regions of Alberta, specifically a balsam poplar / dogwood and a balsam poplar / bracted honeysuckle community type (Beckingham and Archibald 1996; Beckingham et al. 1996). Both communities had a subhygric moisture regime and were nutrient rich. These sites tended to be found in lower slope positions and typically had fine textured soils. Common understorey species included: Cornus stolonifera, Lonicera involucrata, Salix. spp., Aralia nudicaulis and Rubus pubescens. The same authors also documented a balsam poplar / horsetail community type (Beckingham and Archibald 1996; Beckingham et al. 1996) from the Boreal Mixedwood and foothills subregions. This community typically had a subhygric to hygric moisture regime and was nutrient rich. It was commonly found on fine textured materials where flooding or seepage occurred. Common understorey species include Salix spp., Rosa acicularis, Cornus stolonifera, Equisetum arvense, E. pratense and Calamagrostis canadensis.

Table 29. Similarity rating for Populus balsamifera / Corylus cornuta - Cornus stolonifera / Aralia nudicaulis community types documented within Alberta.

\begin{tabular}{|c|c|c|}
\hline $\begin{array}{l}\text { Similar Communities and } \\
\text { Citations }\end{array}$ & $\begin{array}{l}\text { Similarity } \\
\text { Rating }\end{array}$ & Comments \\
\hline Balsam poplar community type (Fehr 1984) & 1 & $\begin{array}{l}\text { This community is the same in terms of site characteristics, } \\
\text { stand structure and species composition. }\end{array}$ \\
\hline $\begin{array}{l}\text { Populus balsamifera / Viburnum opulus - } \\
\text { Cornus stolonifera / Aralia nudicaulis } \\
\text { (Wheatley and Bentz 2002) }\end{array}$ & 1 & $\begin{array}{l}\text { This community is the same in terms of site characteristics, } \\
\text { stand structure and species composition. }\end{array}$ \\
\hline $\begin{array}{l}\text { Balsam poplar / dogwood (Beckingham and } \\
\text { Archibald 1996) Balsam poplar / bracted } \\
\text { honeysuckle (Beckingham et al. 1996) }\end{array}$ & 2 & $\begin{array}{l}\text { These communities are quite similar floristically to that found } \\
\text { at Wainwright, however the site characteristics are } \\
\text { somewhat different. }\end{array}$ \\
\hline $\begin{array}{l}\text { Balsam poplar / horsetail (Beckingham and } \\
\text { Archibald 1996; Beckingham et al. 1996) }\end{array}$ & 3 & $\begin{array}{l}\text { These communities are somewhat similar floristically to that } \\
\text { found at Wainwright, however the site characteristics are } \\
\text { quite different. }\end{array}$ \\
\hline
\end{tabular}

Few related community types have been recorded outside of Alberta, as shown in Table 30. Thorpe and Godwin (1993) described a Populus balsamifera moist community type that community was characterized by balsam poplar forests found on moderately well to poorly drained sandy and clay loam in the Manito Sandhills of Saskatchewan. Common species included Symphoricarpos occidentalis, Salix spp., Rosa spp., Cornus stolonifera, Rubus strigosus, Aralia nudicaulis, Pyrola asarifolia, Smilacina stellata and Carex species. NatureServe (2003) documented two balsam poplar community types, although these involve a different subspecies (i.e. ssp. trichocarpa).

Table 30. Similarity rating for Populus balsamifera / Corylus cornuta - Cornus stolonifera / Aralia nudicaulis community types documented outside Alberta.

\begin{tabular}{|c|c|c|}
\hline $\begin{array}{l}\text { Similar Communities and } \\
\text { Citations }\end{array}$ & $\begin{array}{l}\text { Similarity } \\
\text { Rating }\end{array}$ & Comments \\
\hline $\begin{array}{l}\text { Populus balsamifera Moist Community } \\
\text { Type (Thorpe and Godwin 1993) }\end{array}$ & 1 & $\begin{array}{l}\text { This community has quite a similar species composition and very } \\
\text { similar site conditions. }\end{array}$ \\
\hline
\end{tabular}




\subsubsection{Preliminary Conservation Ranking of Populus balsamifera / Corylus cornuta - Cornus stolonifera / Aralia nudicaulis Community \\ Preliminary Rank: S5}

Populus balsamifera dominated communities are widespread throughout Alberta and other jurisdictions, though they typically do not cover large areas. Specifically, Populus balsamifera / Corylus cornuta - Cornus stolonifera / Aralia nudicaulis communities are well-known types from the Central and Dry Mixedwood subregions (Beckingham and Archibald 1996) as well as the Lower and Upper Foothills subregions (Beckingham et al. 1996). The main limitations to the occurrence of this community type are the availability of moisture and nutrients. While the communities described from Wainwright occur on a sandy substrate, this is not a restriction to the distribution of this community. These communities do not tend to have very large sizes where they occur, however they are quite common when the edaphic conditions are right.

A preliminary rank of $\mathbf{S 5}$ is suggested for this community type, as it appears to be quite widespread. 


\subsection{Populus tremuloides / Juniperus horizontalis / Carex siccata Association}

Aspen / creeping juniper / hay sedge

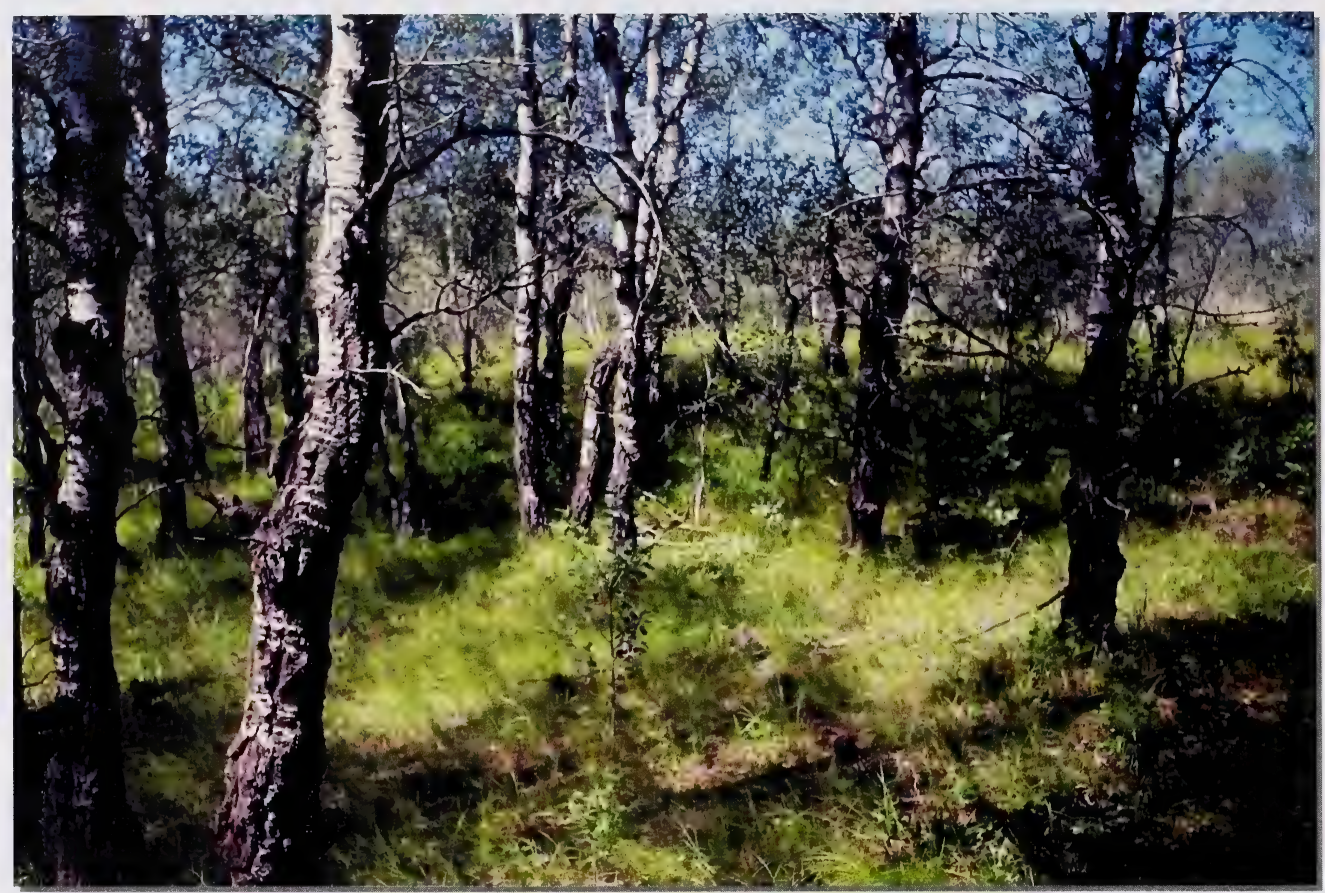

Plate 7. Populus tremuloides / Juniperus horizontalis / Carex siccata community type (Aspen / creeping juniper / hay sedge) Plot 2.

The Populus tremuloides / Juniperus horizontalis / Carex siccata community covered an extensive area, and occurred throughout the Wainwright Dunes Ecological Reserve. It generally occurred in a mosaic-type pattern with small open areas of the Stipa comata Artemisia frigida - Selaginella densa community (see section 3.14). Populus tremuloides was dominant, both in the overstorey or occurring as a tall shrub. In many instances, $P$. tremuloides had quite a 'scrubby' appearance and was stunted in size. Juniperus horizontalis was the dominant shrub, occurring in all the sites sampled. Occasionally other shrub species, such as Prunus virginiana, Rosa acicularis, and Arctostaphylos uva-ursi were encountered however they did not occur at all sites, and typically had less than $5 \%$ cover. Forb species such as Solidago missouriensis, Lathyrus ochroleucus, Chenopodium pratericola and Galium boreale were encountered, but none were prominent in the sites sampled. Graminoids typically formed the dominant understorey, with Carex siccata having the highest cover; typically around $30 \%$. Other species, including Poa pratensis, Calamovilfa longifolia, Festuca saximontana, Koeleria macrantha, and Schizachne purpurescens were common at most sites however they typically had relatively low percent covers. Table 31 summarizes the species composition, mean percent cover, standard error and species prominence for this community type. 
Table 31. Summary statistics for the Populus tremuloides / Juniperus horizontalis / Carex siccata community type $(n=5)$.

\begin{tabular}{|c|c|c|c|c|c|}
\hline Species & $\begin{array}{l}\text { Mean } \% \\
\text { Cover }\end{array}$ & $\begin{array}{l}\text { Standard } \\
\text { Deviation }\end{array}$ & $\begin{array}{l}\text { Standard } \\
\text { Error }\end{array}$ & Presence & Prominence \\
\hline Populus tremuloides & 37.2 & 10.0 & 4.5 & 5 & 37.2 \\
\hline Carex siccata & 30.0 & 21.8 & 9.7 & 5 & 30.0 \\
\hline Juniperus horizontalis & 16.4 & 8.4 & 3.7 & 5 & 16.4 \\
\hline Poa pratensis & 6.6 & 13.1 & 5.9 & 3 & 8.5 \\
\hline $\begin{array}{l}\text { Arctostaphylos uva- } \\
\text { ursi }\end{array}$ & 5.4 & 6.8 & 3.0 & 3 & 7.0 \\
\hline Spirea alba & 2.0 & 2.7 & 1.2 & 2 & 3.2 \\
\hline Solidago missouriensis & 2.4 & 2.5 & 1.1 & 3 & 3.1 \\
\hline Calamovilfa Iongifolia & 2.7 & 4.1 & 1.9 & 4 & 3.0 \\
\hline $\begin{array}{l}\text { Carex pensylvanica } \\
\text { ssp. heliophila }\end{array}$ & 1.6 & 2.3 & 1.0 & 2 & 2.5 \\
\hline Festuca saximontana & 2.2 & 2.8 & 1.2 & 4 & 2.5 \\
\hline Rosa acicularis & 1.9 & 2.1 & 0.9 & 3 & 2.5 \\
\hline Oryzopsis asperifolia & 1.0 & 2.2 & 1.0 & 1 & 2.2 \\
\hline Selaginella densa & 1.4 & 2.2 & 1.0 & 2 & 2.2 \\
\hline Koeleria macrantha & 1.6 & 2.1 & 0.9 & 4 & 1.8 \\
\hline Cladina mitis & 1.0 & 1.4 & 0.6 & 2 & 1.6 \\
\hline Prunus virginiana & 1.1 & 1.0 & 0.5 & 3 & 1.4 \\
\hline $\begin{array}{l}\text { Schizachne } \\
\text { purpurescens }\end{array}$ & 0.8 & 0.8 & 0.4 & 3 & 1.0 \\
\hline Lathyrus ochroleucus & 0.6 & 0.9 & 0.4 & 2 & 0.9 \\
\hline Comandra umbellata & 0.4 & 0.9 & 0.4 & 1 & 0.9 \\
\hline Stipa comata & 0.4 & 0.9 & 0.4 & 1 & 0.9 \\
\hline Gallium boreale & 0.6 & 0.5 & 0.2 & 3 & 0.8 \\
\hline $\begin{array}{l}\text { Chenopodium } \\
\text { pratericola }\end{array}$ & 0.5 & 0.5 & 0.2 & 3 & 0.6 \\
\hline
\end{tabular}

\begin{tabular}{|c|c|c|c|c|c|}
\hline Species & $\begin{array}{l}\text { Mean \% } \\
\text { Cover }\end{array}$ & $\begin{array}{l}\text { Standard } \\
\text { Deviation }\end{array}$ & $\begin{array}{l}\text { Standard } \\
\text { Error }\end{array}$ & Presence & Prominence \\
\hline Artemisia ludoviciana & 0.4 & 0.5 & 0.2 & 2 & 0.6 \\
\hline Festuca hallii & 0.4 & 0.5 & 0.2 & 2 & 0.6 \\
\hline Solidago spathulata & 0.4 & 0.5 & 0.2 & 2 & 0.6 \\
\hline Viola adunca & 0.4 & 0.4 & 0.2 & 3 & 0.5 \\
\hline $\begin{array}{l}\text { Thermopsis } \\
\text { rhombifolia }\end{array}$ & 0.3 & 0.4 & 0.2 & 2 & 0.5 \\
\hline Agrostis scabra & 0.2 & 0.4 & 0.2 & 1 & 0.4 \\
\hline Anemone multifida & 0.2 & 0.4 & 0.2 & 1 & 0.4 \\
\hline Aster ciliolatus & 0.2 & 0.4 & 0.2 & 1 & 0.4 \\
\hline Cladonia uncialis & 0.2 & 0.4 & 0.2 & 1 & 0.4 \\
\hline Descurainia sophia & 0.2 & 0.4 & 0.2 & 1 & 0.4 \\
\hline Heterotheca villosa & 0.2 & 0.4 & 0.2 & 1 & 0.4 \\
\hline Poa interior & 0.2 & 0.4 & 0.2 & 1 & 0.4 \\
\hline Populus balsamifera & 0.2 & 0.4 & 0.2 & 1 & 0.4 \\
\hline Rosa arkansana & 0.2 & 0.4 & 0.2 & 1 & 0.4 \\
\hline Salix bebbiana & 0.2 & 0.4 & 0.2 & 1 & 0.4 \\
\hline Symphoricarpos albus & 0.2 & 0.4 & 0.2 & 1 & 0.4 \\
\hline $\begin{array}{l}\text { Chenopodium } \\
\text { leptophyllum }\end{array}$ & 0.2 & 0.4 & 0.2 & 2 & 0.3 \\
\hline Erigeron glabellus & 0.2 & 0.3 & 0.1 & 2 & 0.3 \\
\hline Agoseris glauca & 0.1 & 0.2 & 0.1 & 1 & 0.2 \\
\hline Arabis holboellii & 0.1 & 0.2 & 0.1 & 1 & 0.2 \\
\hline Chenopodium album & 0.1 & 0.2 & 0.1 & 1 & 0.2 \\
\hline Heuchera richardsonii & 0.1 & 0.2 & 0.1 & 1 & 0.2 \\
\hline Equisetum hymenale & 0.1 & 0.2 & 0.1 & 2 & 0.2 \\
\hline
\end{tabular}

This community was generally found on level to gently sloping (less than $5 \%$ ) sand plains that were typically well drained. The ground surface had a relatively shallow accumulation of organic materials, with some decaying wood. A summary of site data is provided in Table 32.

Table 32. Summary of site data for the Populus tremuloides / Juniperus horizontalis / Carex siccata community type $(n=5)$.

\begin{tabular}{cccccccccc}
\hline Plot Elevation & Slope & Aspect & Drainage & Site Position & $\begin{array}{c}\text { Surface } \\
\text { Shape }\end{array}$ & $\begin{array}{c}\text { Moisture } \\
\text { Regime }\end{array}$ & $\begin{array}{c}\text { Nutrient } \\
\text { Regime }\end{array}$ \\
\hline 2 & 687 & 4 & 188 & Well & Middle Slope & Straight & Submesic & Poor \\
\hline 6 & 685 & 0 & $\mathrm{n} / \mathrm{a}$ & Well & Crest & Convex & Submesic & Medium \\
\hline 17 & 670 & 4 & 27 & Well & Middle Slope & Straight & Subxeric & Medium \\
\hline 23 & 670 & 0 & $\mathrm{n} / \mathrm{a}$ & Well & Toe & Concave & Submesic & Medium \\
\hline 37 & 670 & 0 & $\mathrm{n} / \mathrm{a}$ & Moderately Well & Depression & Concave & Submesic & Medium \\
\hline \hline
\end{tabular}




\subsubsection{Comparison of Populus tremuloides / Juniperus horizontalis / Carex siccata Community to Literature}

Previous studies in the Wainwright Dunes Ecological Reserve and elsewhere in Alberta have identified related community types and these are listed in Table 33. Fehr, in a 1984 survey of the Wainwright Dunes Ecological Reserve, documented a subxeric to submesic aspen community found on sand flats or undulating plain and on dunes. Communities had well-developed aspen canopy (57.6\% cover) but not a well-developed low shrub layer. The herb-dwarf shrub layer averaged $57.5 \%$ cover with Carex foenea, Thermopsis rhombifolia, Galium boreale, Lathyrus ochroleucus, Smilacina stellata and Juniperus horizontalis as the dominant species in this layer. A Populus tremuloides / Juniperus horizontalis / Cladina mitis community has been described from the Central Parkland in the Wainwright Dunes Ecological Reserve as well as at Dillberry Lake Provincial Park (Meijer and Karpuk 1999). In both cases, the community was described as having a short aspen overstorey $(2 \mathrm{~m}$ ) with approximately $20 \%$ cover of Juniperus horizontalis. This community was typically found in interdune depressions or upper slope positions of short, south-facing slopes. Generally sites were xeric and rapidly drained. Associated species often included Rosa acicularis, Salix bebbiana, Artemisia campestris, Selaginella densa and Calamovilfa longifolia. While this community was quite similar floristically, it is structurally somewhat different that observed in the 2003 Wainwright survey. A Populus tremuloides / (sparse understorey) community was described from the Central Parkland subregion, where it was found on depressional sites as well as gently to moderately sloping sites with a northerly to southerly aspect. The community consists of young (<30 years old) aspen, with little or no understorey growth. While the scrubby aspen community in the sand flats of the Ecological Reserve is quite young, they do tend to have a somewhat developed understorey, at least as far as dwarf-shrub and graminoids are concerned. A Populus tremuloides / Juniperus horizontalis community was described from Dillberry Lake Provincial Park on a shallow, south-facing slope that was rapidly drained (Meijer and Karpuk 1999). It was considered to be subxeric, and associated species included Solidago missouriensis, Calamovilfa longifolia, Carex obtusata and Cladina mitis. Additional Populus tremuloides communities have been documented for Alberta and the most relevant types are documented and assessed in Table 22. Many other Populus tremuloides-dominated community types have been described for Alberta, however most do not share many site or floristic characteristics and thus have not been discussed.

Various related community types have been recorded outside of Alberta and they are listed in Table 34. Thorpe and Godwin (1993) described a Populus tremuloides sand type from the Manito Sandhills in Saskatchewan. This community was characterized by aspen forests found on upland, north-facing or lower slope positions as well as on more stabilized landforms. This community was found to be most widespread occurring community type in Manito Sandhills. The authors also documented a Populus tremuloides loam type, forests found on well to moderately well drained sandy loam to clay loam soils. Common species included Symphoricarpos occidentalis, Rubus strigosus, Amelanchier alnifolia, Rosa woodsii, Galium boreale, Thalictrum venulosum, Fragaria virginiana and Carex siccata. .

A Populus tremuloides / Corylus spp. / Andropogon gerardii woodland community has been described from the aspen parkland region of the upper midwestern United States and adjacent Canada, ranging from Minnesota to Manitoba (Faber-Langendoen 2001). This community was typically found on level to rolling terrain. The canopy was typically quite open but this characteristic could vary. Populus tremuloides was the dominant 
overstorey species, although Populus grandidentata and Populus balsamifera were dominant in certain areas.

Table 33. Similarity rating for Populus tremuloides / Juniperus horizontalis / Carex siccata community types documented within Alberta.

\begin{tabular}{|l|c|l|}
\hline \multicolumn{1}{|c|}{$\begin{array}{c}\text { Similar Alberta Communities and } \\
\text { Citations }\end{array}$} & $\begin{array}{c}\text { Similarity } \\
\text { Rating }\end{array}$ & Comments \\
\hline Subxeric to submesic aspen (Fehr 1984) & 1 & $\begin{array}{l}\text { This is the same community type in terms of site } \\
\text { characteristics, although the species composition is slightly } \\
\text { different. }\end{array}$ \\
\hline $\begin{array}{l}\text { Populus tremuloides / Juniperus horizontalis / } \\
\text { Cladina mitis (Meijer and Karpuk 1999; Fehr 1984) }\end{array}$ & $\begin{array}{l}\text { While this community is quite similar floristically, it is } \\
\text { structurally somewhat different than that observed in the 2003 } \\
\text { Wainwright survey. Also, there is no mention of Carex siccata } \\
\text { as being a dominant species. }\end{array}$ \\
\hline $\begin{array}{l}\text { Populus tremuloides / (sparse understorey) (Fehr } \\
\text { 1982) }\end{array}$ & 2 & $\begin{array}{l}\text { This community is somewhat similar in site and community } \\
\text { composition, but has several distinct differences. }\end{array}$ \\
\hline $\begin{array}{l}\text { Populus tremuloides / Juniperus horizontalis } \\
\text { (Meijer and Karpuk 1999) }\end{array}$ & $\begin{array}{l}\text { This community, although sharing a couple dominant species, } \\
\text { is structurally and floristically quite different from that found in } \\
\text { the 2003 Wainwright survey. }\end{array}$ \\
\hline
\end{tabular}

The shrub/sapling layer was usually well developed and included Amelanchier alnifolia, Corylus americana, Cornus foenea, Prunus virginiana, Rosa spp., and Rubus spp. On wetter sites, associated species included Betula pumila, Cornus sericea, Salix bebbiana, and Spiraea alba. Although this community is an aspen parkland community type, it has quite a different floristic composition than that found in Wainwright. A number of authors document a Populus tremuloides / Prunus virginiana forest community type from the Rocky Mountains and Black Hills in the western United States (NatureServe 2003; Faber-Langendoen 2001; Marriott and Faber-Langendoen 2000a; Schneider et al. 1997). In the Black Hills, this community tended to occur along mesic valley bottoms where slopes varied from steep to gentle. While deciduous trees dominated the community, there a small component of evergreen trees Picea glauca (in the Black Hills) and Pinus ponderosa could occasionally be found. Common understorey species included Prunus virginiana, Amelanchier alnifolia, Ribes spp., and Symphoricarpos spp.. Several authors also documented a Populus tremuloides / Prunus virginiana woodland community found in the north-central Great Plains of the United States and Canada Woodland (NatureServe 2003; Faber-Langendoen 2001; Schneider et al. 1997). In North Dakota, this community occurred on well-drained loam soils. The canopy was moderately dense to dense and was dominated by Populus tremuloides, although Fraxinus pennsylvanica may be a common associate. The shrub layer was typically very well developed and was dominated by Prunus virginiana. Other understorey species included Amelanchier alnifolia, Corylus spp., Rosa spp., and Symphoricarpos occidentalis. Aralia nudicaulis, Maianthemum stellatum, and Galium boreale may be found in the herbaceous layer.

Many other Populus tremuloides-dominated community types have been described outside of Alberta, however most do not share many site or floristic characteristics and thus have not been discussed. 
Table 34. Similarity rating for Populus tremuloides / Juniperus horizontalis / Carex siccata community types documented outside Alberta.

\begin{tabular}{|l|c|l|}
\hline \multicolumn{1}{|c|}{ Similar Communities and Citations } & $\begin{array}{c}\text { Similarity } \\
\text { Rating }\end{array}$ & \multicolumn{1}{|c|}{ Comments } \\
\hline $\begin{array}{l}\text { Populus tremuloides sand type (Thorpe and Godwin } \\
\text { 1993) }\end{array}$ & 2 & $\begin{array}{l}\text { This community has similar overstorey species, } \\
\text { although site conditions are quite different }\end{array}$ \\
\hline $\begin{array}{l}\text { Populus tremuloides loam type (Thorpe and Godwin } \\
\text { 1993) }\end{array}$ & 2 & $\begin{array}{l}\text { This community has quite a similar species composition } \\
\text { though somewhat different site conditions. }\end{array}$ \\
\hline $\begin{array}{l}\text { Populus tremuloides / Corylus spp. / Andropogon } \\
\text { gerardii woodland (NatureServe 2003; Faber- } \\
\text { Langendoen 2001) }\end{array}$ & 3 & $\begin{array}{l}\text { This community has different site characteristics and is } \\
\text { different floristically than that found in Wainwright. }\end{array}$ \\
\hline $\begin{array}{l}\text { Populus tremuloides / Prunus virginiana Forest } \\
\text { (NatureServe 2003; MNHP 2002; Faber-Langendoen } \\
\text { 2001; Marriott and Faber-Langendoen 2000; Schneider } \\
\text { et al. 1997) }\end{array}$ & 3 & $\begin{array}{l}\text { This community has different site characteristics and is } \\
\text { different floristically than that found in Wainwright. }\end{array}$ \\
\hline $\begin{array}{l}\text { Populus tremuloides / Prunus virginiana Woodland } \\
\text { (NatureServe 2003; Faber-Langendoen 2001; } \\
\text { Schneider et al. 1997) }\end{array}$ & 3 & $\begin{array}{l}\text { This community has different site characteristics and is } \\
\text { different floristically than that found in Wainwright. }\end{array}$ \\
\hline
\end{tabular}

\subsubsection{Preliminary Conservation Ranking of Populus tremuloides / Juniperus horizontalis / Carex siccata Community}

Preliminary Rank: S2S3

This Populus tremuloides dominated community was the most unique of the three aspen-dominated communities that were documented at the Wainwright Dunes Ecological Reserve. This community was generally found on level to gently sloping sand plains and covered an extensive area. It generally occurred in a mosaic type pattern with more open areas of the Artemisia frigida - Selaginella densa - Stipa comata community. In many instances, $P$. tremuloides had quite a 'scrubby' appearance and was stunted in size. Fehr described a similar community type and distribution in a 1984 inventory of the same area, however similar communities have not been discussed elsewhere in the literature.

As such a preliminary rank of $\mathbf{S 2 S 3}$ is suggested for this community type. Additional sampling in sand dune and sand plain landscapes outside the Wainwright Dunes Ecological Reserve may help to clarify the status and overall geographic extent of this community type. 


\subsection{Populus tremuloides / Prunus virginiana - Amelanchier alnifolia / Carex siccata Association}

Aspen / chokecherry - saskatoon / hay sedge

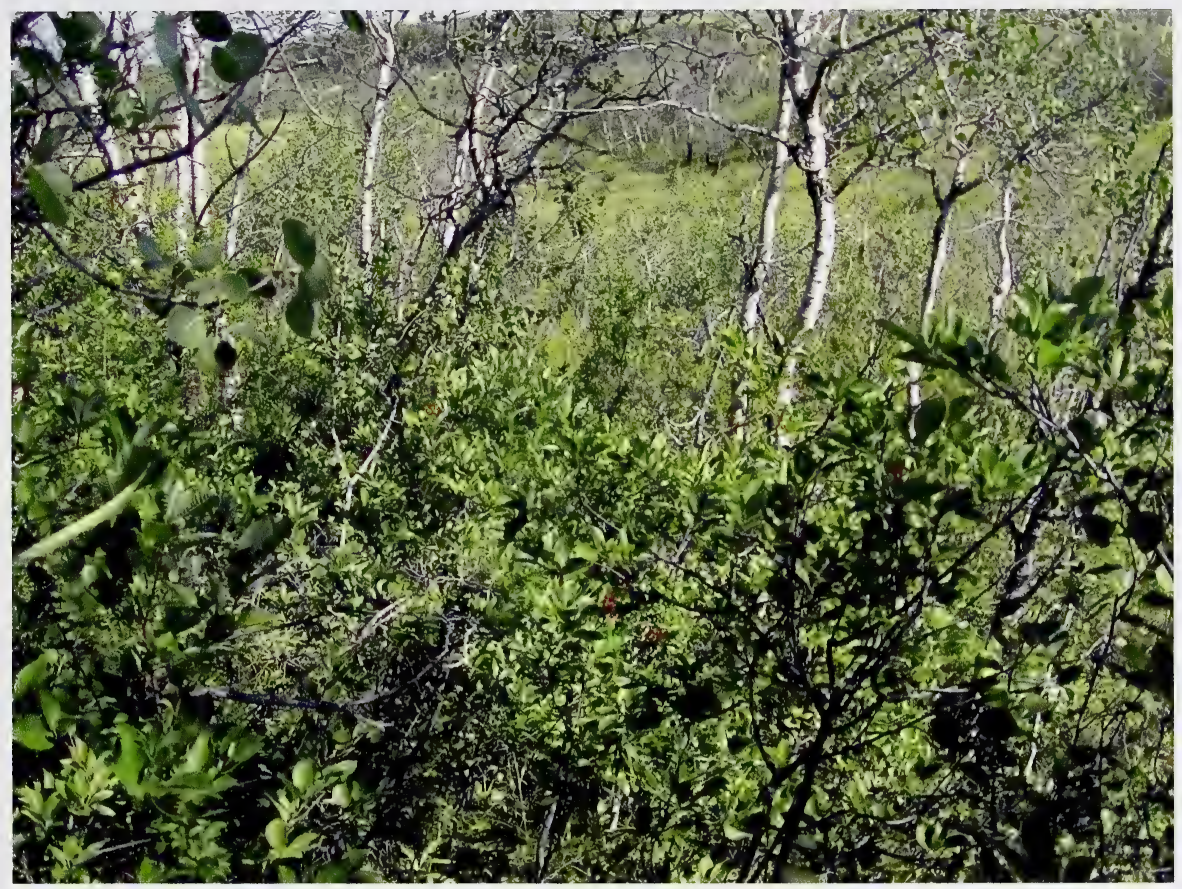

Plate 8. Populus tremuloides / Prunus virginiana - Amelanchier alnifolia / Carex siccata community type (Aspen / chokecherry - saskatoon / hay sedge) Plot 29.

The Populus tremuloides / Prunus virginiana - Amelanchier alnifolia / Carex siccata community type was quite common through the Wainwright Dunes Ecological Reserve, though limited in its distribution. It was found on steep, generally northeast facing slopes on the leeward side of dunes. It typically only covered the 7-10 metre long slope, until leveling out into a grassland or more open stand. A very high shrub cover, relatively high grass cover and few forbs characterize this community. Populus tremuloides was the dominant species, typically having a cover of around $40 \%$. Shrub cover was very high, commonly exceeded $50 \%$ cover. The most common shrub species were Prunus virginiana and Amelanchier alnifolia although Rosa acicularis, Rhus radicans, Symphoricarpos alba and Juniperus horizontalis were also quite common. Carex siccata was the dominant graminoid, with a mean cover of approximately $10 \%$, however Elymus canadensis, Poa pratensis, Schizachne purpurescens were also found. Total forb cover was generally less than $10 \%$, although the diversity in forb species encountered was quite variable. Lathyrus ochroleucus, Galium boreale and Aster ciliolatus (likely a subspecies or variety) were found in all sites sampled. Table 35 summarizes the species composition, mean percent cover, standard error and species prominence for this community type. 
Table 35. Summary statistics for the Populus tremuloides / Prunus virginiana Amelanchier alnifolia / Carex siccata community type $(n=4)$.

\begin{tabular}{|c|c|c|c|c|}
\hline Species & $\begin{array}{c}\text { Mean \% } \\
\text { Cover }\end{array}$ & $\begin{array}{l}\text { Standard } \\
\text { Error }\end{array}$ & Presence & Prominence \\
\hline Populus tremuloides & 40.6 & 5.3 & 4 & 40.6 \\
\hline Prunus virginiana & 22.3 & 8.8 & 4 & 22.3 \\
\hline Amelanchier alnifolia & 11.9 & 5.5 & 4 & 11.9 \\
\hline Carex siccata & 10.5 & 5.9 & 4 & 10.5 \\
\hline Rosa acicularis & 8.0 & 3.4 & 3 & 9.2 \\
\hline Spirea alba & 2.8 & 2.8 & 1 & 5.5 \\
\hline Rhus radicans & 3.0 & 2.4 & 2 & 4.2 \\
\hline $\begin{array}{l}\text { Symphoricarpos } \\
\text { albus }\end{array}$ & 3.8 & 1.7 & 4 & 3.8 \\
\hline Oryzopsis asperifolia & 1.8 & 1.8 & 1 & 3.5 \\
\hline $\begin{array}{l}\text { Juniperus } \\
\text { horizontalis } \\
\end{array}$ & 3.3 & 1.3 & 4 & 3.3 \\
\hline Juniperus communis & 1.3 & 1.3 & 1 & 2.5 \\
\hline Elymus candensis & 1.5 & 1.2 & 2 & 2.1 \\
\hline Poa pratensis & 1.5 & 1.2 & 2 & 2.1 \\
\hline $\begin{array}{l}\text { Thermopsis } \\
\text { rhombifolia }\end{array}$ & 1.0 & 1.0 & 1 & 2.0 \\
\hline $\begin{array}{l}\text { Schizachne } \\
\text { purpurescens }\end{array}$ & 1.6 & 1.1 & 3 & 1.9 \\
\hline Gallium boreale & 1.8 & 0.3 & 4 & 1.8 \\
\hline $\begin{array}{l}\text { Arctostaphylos uva- } \\
\text { ursi }\end{array}$ & 1.0 & 0.6 & 2 & 1.4 \\
\hline $\begin{array}{l}\text { Elaeagnus } \\
\text { commutata }\end{array}$ & 0.6 & 0.6 & 1 & 1.3 \\
\hline Lonicera dioica & 0.8 & 0.7 & 2 & 1.1 \\
\hline Cladina mitis & 0.5 & 0.5 & 1 & 1.0 \\
\hline Comandra umbellata & 0.5 & 0.5 & 1 & 1.0 \\
\hline $\begin{array}{l}\text { Maianthemum } \\
\text { candense }\end{array}$ & 0.5 & 0.5 & 1 & 1.0 \\
\hline
\end{tabular}

\begin{tabular}{|c|c|c|c|c|}
\hline Species . . . . . . & $\begin{array}{c}\text { Mean \% } \\
\text { Cover }\end{array}$ & $\begin{array}{c}\text { Standard } \\
\text { Error }\end{array}$ & Presence & Prominence \\
\hline Stipa spartea & 0.5 & 0.5 & 1 & 1.0 \\
\hline Lathyrus ochroleucus & 0.9 & 0.1 & 4 & 0.9 \\
\hline Smilacina stellata & 0.8 & 0.3 & 3 & 0.9 \\
\hline Aster ciliolatus & 0.8 & 0.1 & 4 & 0.8 \\
\hline $\begin{array}{l}\text { Symphoricarpos } \\
\text { occidentalis }\end{array}$ & 0.4 & 0.4 & 1 & 0.8 \\
\hline Viola canadensis & 0.5 & 0.3 & 2 & 0.7 \\
\hline Aralia nudicaulis & 0.3 & 0.3 & 1 & 0.5 \\
\hline Equisetum hymenale & 0.3 & 0.3 & 1 & 0.5 \\
\hline Festuca saximontana & 0.3 & 0.3 & 1 & 0.5 \\
\hline Juncus balticus & 0.3 & 0.3 & 1 & 0.5 \\
\hline $\begin{array}{l}\text { Ribes } \\
\text { oxyacanthoides }\end{array}$ & 0.3 & 0.3 & 1 & 0.5 \\
\hline $\begin{array}{l}\text { Heuchera } \\
\text { richardsonii }\end{array}$ & 0.3 & 0.1 & 2 & 0.4 \\
\hline Bromus inermis & 0.1 & 0.1 & 1 & 0.3 \\
\hline $\begin{array}{l}\text { Disporum } \\
\text { trachycarpum }\end{array}$ & 0.1 & 0.1 & 1 & 0.3 \\
\hline Erigeron glabellus & 0.1 & 0.1 & 1 & 0.3 \\
\hline Fragaria virginiana & 0.1 & 0.1 & 1 & 0.3 \\
\hline Rubus idaeus & 0.1 & 0.1 & 1 & 0.3 \\
\hline Solidago candensis & 0.1 & 0.1 & 1 & 0.3 \\
\hline $\begin{array}{l}\text { Solidago } \\
\text { missouriensis }\end{array}$ & 0.1 & 0.1 & 1 & 0.3 \\
\hline $\begin{array}{l}\text { Thalictrum } \\
\text { venulosum }\end{array}$ & 0.1 & 0.1 & 1 & 0.3 \\
\hline Viola adunca & 0.1 & 0.1 & 1 & 0.3 \\
\hline
\end{tabular}

This community was generally found on steep (30 - $60 \%$ ) slopes with a northeasterly aspect. The soil surface typically had a shallow accumulation of organic matter, with some decaying wood. Sites were typically well drained, with a submesic moisture regime. A summary of site data is provided in Table 36.

Table 36. Summary of site data for the Populus tremuloides / Prunus virginiana Amelanchier alnifolia / Carex siccata community type $(n=4)$.

\begin{tabular}{cccccccccc}
\hline Plot Elevation & Slope & Aspect & Drainage & Site Position & $\begin{array}{c}\text { Surface } \\
\text { Shape }\end{array}$ & $\begin{array}{c}\text { Moisture } \\
\text { Regime }\end{array}$ & $\begin{array}{l}\text { Nutrient } \\
\text { Regime }\end{array}$ \\
\hline 11 & 691 & 34 & 33 & Well & Middle Slope & Straight & Submesic & Medium \\
\hline 25 & 670 & 42 & 65 & Well & Middle Slope & Straight & Submesic & Medium \\
\hline 29 & 692 & 56 & 40 & Well & Middle Slope & Straight & Submesic & Medium \\
\hline 36 & 679 & 0 & n/a & Moderately Well & Level & Straight & Submesic & Medium \\
\hline \hline
\end{tabular}




\subsubsection{Comparison of Populus tremuloides / Prunus virginiana - Amelanchier alnifolia / Carex siccata Community to Literature}

Previous studies in the Wainwright Dunes Ecological Reserve and elsewhere in Alberta have identified related community types, and these are listed in Table 37. Fehr (1984) described a "north-facing dune dense aspen" community type from the Wainwright Dunes Ecological Reserve. This community was located on dunes averaging $32^{\circ}$ slope and oriented towards the northeast. The communities had a subxeric to submesic moisture regime but some were more mesic. Overstorey aspen cover ranged from 10$70 \%$ but averaged at about $42 \%$. Understorey shrub cover averaged $43 \%$ and ranged from $30-60 \%$. The dominant species were Prunus virginiana, Rosa acicularis, Spirea alba, Prunus pensylvanica and Symphoricarpos albus. A Populus tremuloides / (sparse understorey) community was described from the Central Parkland subregion, where it was found on depressional sites as well as gently to moderately sloping sites with a northerly to southerly aspect (Wheatley and Bentz 2002). The community consisted of young (<30 years old) aspen, with little or no understorey growth. While the scrubby aspen community in the sand flats of the Ecological Reserve is quite young, they do tend to have a somewhat developed understorey, at least as far as dwarf-shrub and graminoids are concerned. A Populus tremuloides / Prunus virginiana - (Shrub) / Low Herb community has been described from the Central Parkland where it is found several locations. Meijer and Karpuk (1999) described this community from the Dillberry Lake area, where it occurred on upland eolian and glaciofluvial materials, on upper slopes where there was little moisture accumulation. Pearson Timberline (1993) noted this community from the Wainwright Dunes area, where it was found on dry sandy outwash plains, dune complexes, depressions and kame moraines. The slope ranged from 0$70 \%$. Other noted species include: Amelanchier alnifolia, Symphoricarpos occidentalis, Rosa spp., Juniperus horizontalis, Lathyrus ochroleucus, Schizachne purpurescens, Carex foenea, Thermopsis rhombifolia, Smilacina stellata and Galium boreale. Adams et al. (1997) described a Populus tremuloides / Symphoricarpos occidentalis community dominated by aspen in the overstorey, with Symphoricarpos occidentalis, Salix spp., and Betula occidentalis in the shrub understorey. Agropyron trachycaulum was noted to be the dominant graminoid. This community was found on a variety of parent materials, but they were dominantly sandy. Slopes ranged up to $10 \%$ but typically had a southeasterly aspect. Adams et al. (1997) also noted a general Populus tremuloides community type unfortunately no further information was provided. Many other Populus tremuloidesdominated community types have been described for Alberta, however most do not share many site or floristic characteristics and thus have not been discussed.

Various related community types have been recorded outside of Alberta and these are listed in Table 38. Thorpe and Godwin (1993) described a Populus tremuloides sand type from the Manito Sandhills in Saskatchewan. This community was characterized by aspen forests found on upland, north-facing or lower slope positions as well as on more stabilized landforms. This community was found to be most widespread occurring community type in Manito Sandhills. The authors also documented a Populus tremuloides loam type, forests found on well to moderately well drained sandy loam to clay loam soils. Common species included Symphoricarpos occidentalis, Rubus strigosus, Amelanchier alnifolia, Rosa woodsii, Galium boreale, Thalictrum venulosum, Fragaria virginiana and Carex siccata. 
Table 37. Similarity rating for Populus tremuloides / Prunus virginiana - Amelanchier alnifolia / Carex siccata community types documented within Alberta.

\begin{tabular}{|l|c|l|}
\hline Similar Communities and Citations & $\begin{array}{c}\text { Similarity } \\
\text { Rating }\end{array}$ & Comments \\
\hline North-facing dune dense aspen (Fehr 1984) & 1 & $\begin{array}{l}\text { This is the same community type in terms of site characteristics } \\
\text { with only a few minor differences in understorey species } \\
\text { composition. }\end{array}$ \\
\hline $\begin{array}{l}\text { Populus tremuloides / (sparse understorey) } \\
\text { (Wheatley and Bentz 2002; Fehr 1982) }\end{array}$ & 2 & $\begin{array}{l}\text { This community is somewhat similar in site characteristics, but } \\
\text { has a substantially different species composition and structure. }\end{array}$ \\
\hline $\begin{array}{l}\text { Populus tremuloides / Prunus virginiana - (Shrub) / } \\
\text { Low Herb (Meijer and Karpuk 1999; Fehr 1984; } \\
\text { Pearson Timberline 1993) }\end{array}$ & 3 & $\begin{array}{l}\text { The sites documented in the literature and the species } \\
\text { composition and stand structure are quite different than those } \\
\text { observed in this type. }\end{array}$ \\
\hline $\begin{array}{l}\text { Populus tremuloides / Symphoricarpos occidentalis } \\
\text { (Adams et al. 1997) }\end{array}$ & 3 & $\begin{array}{l}\text { This community is quite different floristically and in site } \\
\text { characteristics than that found in the Wainwright area. }\end{array}$ \\
\hline Populus tremuloides (Adams et al. 1997) & $?$ & $\begin{array}{l}\text { There is no information provided regarding the floristic } \\
\text { composition and site characteristics of this community as it is } \\
\text { considered to be minor or indistinct community that will be } \\
\text { further developed with additional field sampling. As such it is } \\
\text { difficult to assess its similarity to the community found in } \\
\text { Wainwright. }\end{array}$ \\
\hline
\end{tabular}

A number of authors documented a Populus tremuloides / Prunus virginiana forest community type from the Rocky Mountains and Black Hills in the western United States (NatureServe 2003; Faber-Langendoen 2001; Marriott and Faber-Langendoen 2000a; Schneider et al. 1997). In the Black Hills, this community tended to occur along mesic valley bottoms where slopes varied from steep to gentle. While deciduous trees dominated the community, there a small component of evergreen trees Picea glauca (in the Black Hills) and Pinus ponderosa could occasionally be found. Common understorey species included Prunus virginiana, Amelanchier alnifolia, Ribes spp., and Symphoricarpos spp.. Several authors also documented a Populus tremuloides / Prunus virginiana woodland community found in the north-central Great Plains of the United States and Canada Woodland (NatureServe 2003; Faber-Langendoen 2001; Schneider et al. 1997). In North Dakota, this community occurred on well-drained loam soils. The canopy was moderately dense to dense and was dominated by Populus tremuloides, although Fraxinus pennsylvanica may be a common associate. The shrub layer was typically very well developed and was dominated by Prunus virginiana. Other understorey species included Amelanchier alnifolia, Corylus spp., Rosa spp., and Symphoricarpos occidentalis. Aralia nudicaulis, Maianthemum stellatum, and Galium boreale may be found in the herbaceous layer. Several authors note a Populus tremuloides / Amelanchier alnifolia forest community type (NatureServe 2003; MNHP 2002) and a Populus tremuloides / Amelanchier alnifolia / Tall forb community type (NatureServe 2003; Rust 1997) unfortunately no further information is provided for either community.

Numerous other Populus tremuloides-dominated community types have been described outside of Alberta, however most do not share many site or floristic characteristics and thus have not been discussed. 
Table 38. Similarity rating for Populus tremuloides / Prunus virginiana - Amelanchier alnifolia / Carex siccata community types documented outside Alberta.

\begin{tabular}{|l|c|l|}
\hline \multicolumn{1}{|c|}{ Similar Communities and Citations } & $\begin{array}{c}\text { Similarity } \\
\text { Rating }\end{array}$ & \multicolumn{1}{|c|}{ Comments } \\
\hline $\begin{array}{l}\text { Populus tremuloides sand type (Thorpe and Godwin } \\
\text { 1993) }\end{array}$ & 1 & $\begin{array}{l}\text { This community has quite a similar species composition and } \\
\text { similar site conditions. }\end{array}$ \\
\hline $\begin{array}{l}\text { Populus tremuloides loam type (Thorpe and Godwin } \\
\text { 1993) }\end{array}$ & 2 & $\begin{array}{l}\text { This community has quite a similar species composition } \\
\text { though somewhat different site conditions. }\end{array}$ \\
\hline $\begin{array}{l}\text { Populus tremuloides / Prunus virginiana Forest } \\
\text { (NatureServe 2003; MNHP 2002; Faber-Langendoen } \\
\text { 2001; Marriott and Faber-Langendoen 2000; } \\
\text { Schneider et al. 1997) }\end{array}$ & 2 & $\begin{array}{l}\text { This community has different site characteristics but is quite } \\
\text { similar floristically to that found in Wainwright. }\end{array}$ \\
\hline $\begin{array}{l}\text { Populus tremuloides / Prunus virginiana Woodland } \\
\text { (NatureServe 2003; Faber-Langendoen 2001; }\end{array}$ & 3 & $\begin{array}{l}\text { This community has different site characteristics and is } \\
\text { different floristically than that found in Wainwright. }\end{array}$ \\
\hline $\begin{array}{l}\text { Populus tremuloides / Amelanchier alnifolia / Tall } \\
\text { Forbs (NatureServe 2003; Rust 1997) }\end{array}$ & $?$ & $\begin{array}{l}\text { This community is noted to occur in Idaho, Nevada and } \\
\text { Utah. Unfortunately no further information is provided. Due } \\
\text { to lack of information, cannot assess similarity. }\end{array}$ \\
\hline $\begin{array}{l}\text { Populus tremuloides / Amelanchier alnifolia } \\
\text { Forest(NatureServe 2003; MNHP 2002) }\end{array}$ & $?$ & $\begin{array}{l}\text { This community is noted to occur in Colorado, Montana and } \\
\text { Wyoming, as well as in Ontario. Unfortunately no further } \\
\text { information is provided. Due to lack of information, cannot } \\
\text { assess similarity. }\end{array}$ \\
\hline
\end{tabular}

\subsubsection{Preliminary Conservation Ranking of Populus tremuloides / Prunus virginiana - Amelanchier alnifolia / Carex siccata Community}

Preliminary Rank: S3

This community type was quite common in the Wainwright Dunes Ecological Reserve where it was found on steep, generally northeast facing slopes on the leeward side of dunes. Although the community type occurred in narrow (7-12 metre) strips, it was quite extensive and occurred regularly throughout the landscape.

Communities with a similar, though slightly different, floristic composition are found commonly throughout Alberta and the Aspen Parkland and Great Plains in general (NatureServe 2003; Faber-Langendoen 2001; Marriott and Faber-Langendoen 2000a; Meijer and Karpuk 1999; Schneider et al. 1997; Adams et al. 1997; Pearson Timberline 1993; Fehr 1982). However, the prominence of Carex siccata does indicate a slightly different community type, likely due to the coarse-textured eolian substrate.

A preliminary rank of $\mathbf{S 3}$ is suggested for this community type, as it appears to be quite widespread and relatively common throughout the Wainwright Dunes Ecological Reserve (i.e. greater than 21 occurrences) but not elsewhere in Alberta. Additional sampling in sand dune and sand plain landscapes outside the Wainwright Dunes Ecological Reserve may help to clarify the status and overall geographic extent of this community type. 


\subsection{Populus tremuloides / Amelanchier alnifolia - Rosa acicularis / Poa palustris Association}

Aspen / saskatoon - prickly rose / fowl bluegrass

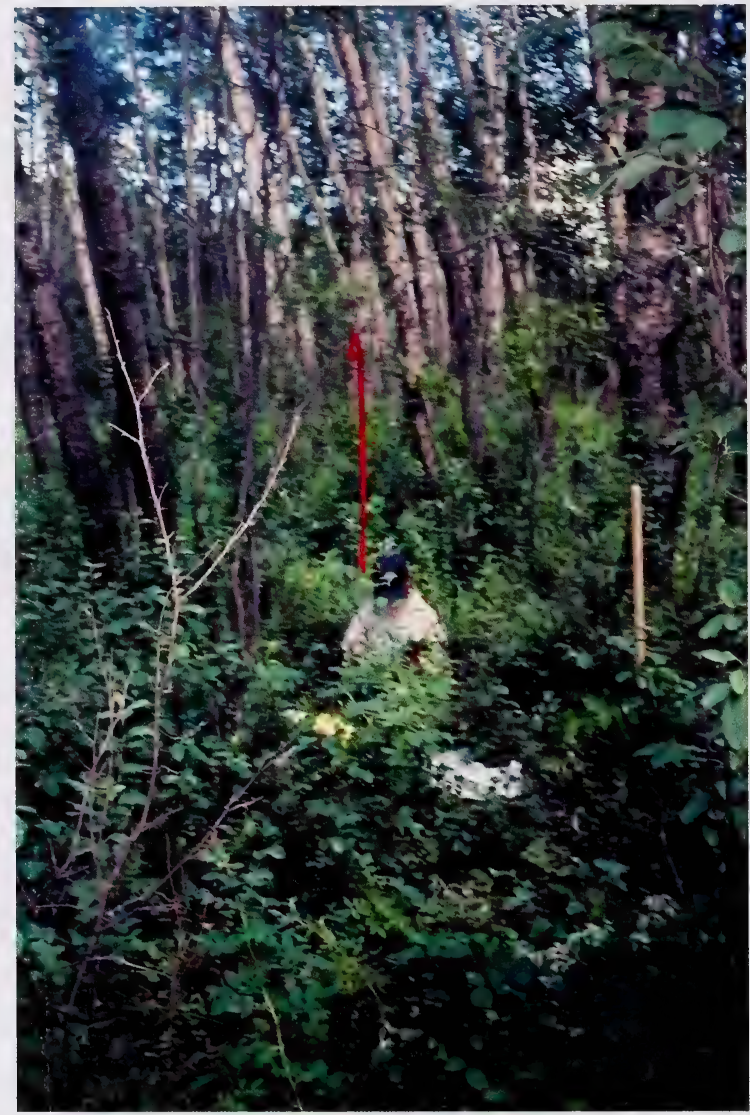

Plate 9. Populus tremuloides / Amelanchier alnifolia - Rosa acicularis / Poa palustris community type (Aspen / saskatoon - prickly rose / fowl bluegrass) Plot 1.

The Populus tremuloides / Amelanchier alnifolia - Rosa acicularis / Poa palustris community type was quite extensive in the Ecological Reserve where moisture was available and it is marked by a high diversity of species. Populus tremuloides was the dominant overstorey species and common shrub species included Amelanchier alnifolia, Rosa acicularis, Cornus stolonifera and Symphoricarpos occidentalis. Shrub cover typically exceeded $70 \%$. Poa palustris cover was also quite high, with other graminoids including Oryzopsis asperifolia and Poa pratensis. Thalictrum venulosum was the dominant forb, with approximately $10 \%$ cover, although Galium boreale, Viola canadensis and Lathyrus ochroleucus were also quite common. Table 39 summarizes the species composition and mean percent cover for this community type. 
Table 39. Summary statistics for the Populus tremuloides / Amelanchier alnifolia - Rosa acicularis / Poa palustris community type $(n=1)$.

\begin{tabular}{ll}
\hline \multicolumn{1}{c}{ Species } & Mean \% Cover \\
\hline a palustris & 50.0 \\
\hline Populus tremuloides & 46.0 \\
\hline Amelanchier alnifolia & 40.0 \\
\hline Rosa acicularis & 30.0 \\
\hline Cornus stolonifera & 11.0 \\
\hline Thalictrum venulosum & 10.0 \\
\hline Symphoricarpos occidentalis & 8.0 \\
\hline Gallium boreale & 6.0 \\
\hline Bromus inermis & 2.0 \\
\hline Viola canadensis & 2.0 \\
\hline Corylus cornuta & 1.0 \\
\hline
\end{tabular}

\begin{tabular}{lc}
\hline \multicolumn{1}{c}{ Species } & Mean \% Cover \\
\hline Fragaria virginiana & 1.0 \\
\hline Lathyrus ochroleucus & 1.0 \\
\hline Oryzopsis asperifolia & 1.0 \\
\hline Salix bebbiana & 1.0 \\
\hline Aster ciliolatus & 0.5 \\
\hline Poa pratensis & 0.5 \\
\hline Prunus virginiana & 0.5 \\
\hline Smilacina stellata & 0.5 \\
\hline Viola adunca & 0.5 \\
\hline Ribes oxyacanthoides & 0.1 \\
\hline \hline
\end{tabular}

This community was found on generally level sites. A summary of site data is provided in Table 40.

Table 40. Summary of site data for the Populus tremuloides / Amelanchier alnifolia Rosa acicularis / Poa palustris community type $(n=1)$.

\begin{tabular}{ccccccccc}
\hline Plot Elevation Slope & Aspect & Drainage & $\begin{array}{c}\text { Site } \\
\text { Position }\end{array}$ & $\begin{array}{c}\text { Surface } \\
\text { Shape }\end{array}$ & $\begin{array}{c}\text { Moisture } \\
\text { Regime }\end{array}$ & $\begin{array}{c}\text { Nutrient } \\
\text { Regime }\end{array}$ \\
\hline 1 & 701 & 1 & $\mathrm{n} / \mathrm{a}$ & Well & Level & Straight & Submesic & Medium \\
\hline \hline
\end{tabular}

\subsubsection{Comparison of Populus tremuloides / Amelanchier alnifolia - Rosa acicularis / Poa palustris Community to Literature}

Previous studies in the Wainwright Dunes Ecological Reserve and elsewhere in Alberta have identified related community types, which are listed in Table 41. Fehr (1984) described mesic aspen communities during a previous biophysical inventory of the Wainwright Dunes Ecological Reserve. Fehr noted mesic aspen stands, often with a secondary tree canopy layer. Three shrub species formed the tall shrub layer, averaging $25 \%$ cover and included Prunus virginiana, Amelanchier alnifolia and Populus tremuloides. The low shrub layer averaged $85 \%$ cover and includes Corylus cornuta, Rosa acicularis, Amelanchier alnifolia, Cornus stolonifera and Rubus strigosus. A Populus tremuloides / (sparse understorey) community was described from the Central Parkland subregion, where it was found on depressional sites as well as gently to moderately sloping sites with a northerly to southerly aspect. The community consists of young ( $<30$ years old) aspen, with little or no understorey growth. While the scrubby aspen community in the sand flats of the Ecological Reserve is quite young, they do tend to have a somewhat developed understorey, at least as far as dwarf-shrub and graminoids are concerned. A Populus tremuloides / Prunus virginiana - (Shrub) / Low Herb community has been described from the Central Parkland where it is found several locations. Meijer and Karpuk (1999) described this community from the Dillberry Lake area, where it occurred on upland eolian and glaciofluvial materials, on upper slopes 
where there was little moisture accumulation. Pearson Timberline (1993) noted this community from the Wainwright Dunes area, where it was found on dry sandy outwash plains, dune complexes, depressions and kame moraines. The slope ranged from 070\%. Other noted species include: Amelanchier alnifolia, Symphoricarpos occidentalis, Rosa spp., Juniperus horizontalis, Lathyrus ochroleucus, Schizachne purpurescens, Carex foenea, Thermopsis rhombifolia, Smilacina stellata and Galium boreale. Adams et al. (1997) described a Populus tremuloides / Symphoricarpos occidentalis community dominated by aspen in the overstorey, with Symphoricarpos occidentalis, Salix spp., and Betula occidentalis in the shrub understorey. Agropyron trachycaulum was noted to be the dominant graminoid. This community was found on a variety of parent materials, but they were dominantly sandy. Slopes ranged up to $10 \%$ but typically had a southeasterly aspect. An aspen / low-bush cranberry community is described for both the Boreal Mixedwood and the foothills regions of Alberta (Beckingham and Archibald 1996; Beckingham et al. 1996). This community was typically found on medium textured, mesic soils. Common understorey species included Viburnum edule, Linnea borealis, Rosa acicularis, Aralia nudicaulis and Calamagrostis canadensis. Adams et al. (1997) also noted a general Populus tremuloides community type unfortunately no further information was provided. Many other Populus tremuloides-dominated community types have been described for Alberta, however most do not share many site or floristic characteristics and thus have not been discussed.

Table 41. Similarity rating for Populus tremuloides / Amelanchier alnifolia - Rosa acicularis / Poa palustris community types documented within Alberta.

\begin{tabular}{|l|c|l|l|}
\hline Similar Communities and Citations & \multicolumn{2}{|c|}{$\begin{array}{l}\text { Similarity } \\
\text { Rating }\end{array}$} & \multicolumn{1}{l|}{ Comments } \\
\hline Mesic aspen communities (Fehr 1984) & 1 & $\begin{array}{l}\text { This community is the same in terms of site characteristics, } \\
\text { stand structure and species composition. }\end{array}$ \\
\hline $\begin{array}{l}\text { Populus tremuloides / (sparse understorey) } \\
\text { (Wheatley and Bentz 2002; Fehr 1982) }\end{array}$ & 3 & $\begin{array}{l}\text { This community is somewhat quite distinctly different in site } \\
\text { and community composition. }\end{array}$ \\
\hline $\begin{array}{l}\text { Populus tremuloides / Prunus virginiana - (Shrub) / } \\
\text { Low Herb (Meijer and Karpuk 1999; Pearson } \\
\text { Timberline 1993; Fehr 1984;) }\end{array}$ & 1 & $\begin{array}{l}\text { The site characteristics documented in the literature matches } \\
\text { the observed sites quite well, and the species composition and } \\
\text { stand structure is also very similar. }\end{array}$ \\
\hline $\begin{array}{l}\text { Populus tremuloides / Symphoricarpos occidentalis } \\
\text { (Adams et al. 1997) }\end{array}$ & 3 & $\begin{array}{l}\text { This community is quite different floristically and in site } \\
\text { characteristics than that found in the Wainwright area. }\end{array}$ \\
\hline $\begin{array}{l}\text { Populus tremuloides (Adams et al. 1997) } \\
\text { composition and site characteristics of this community as it is } \\
\text { considered to be minor or indistinct community that will be } \\
\text { further developed with additional field sampling. As such it is } \\
\text { difficult to assess its similarity to the community found in } \\
\text { Wainwright. }\end{array}$ \\
\hline $\begin{array}{l}\text { Aspen (Birch) / Blueberry (Beckingham and } \\
\text { Archibald 1996) }\end{array}$ & $?$ & $\begin{array}{l}\text { The site characteristics and floristic composition of this } \\
\text { community are quite different than those of the Wainwright } \\
\text { community. }\end{array}$ \\
\hline Aspen / Hairy Wild Rye (Beckingham et al. 1996) & 3 & $\begin{array}{l}\text { The site characteristics and floristic composition of this } \\
\text { community are quite different than those of the Wainwright } \\
\text { community. }\end{array}$ \\
\hline $\begin{array}{l}\text { Aspen / Low-bush cranberry (Beckingham and } \\
\text { Archibald 1996; Beckingham et al. 1996) }\end{array}$ & 2 & $\begin{array}{l}\text { The site characteristics of this community are quite different } \\
\text { than those of the Wainwright community, although floristically } \\
\text { they are quite similar. }\end{array}$ \\
\hline
\end{tabular}

Various related community types have been recorded outside of Alberta, which are listed in Table 42. Thorpe and Godwin (1993) described a Populus tremuloides sand type from the Manito Sandhills in Saskatchewan. This community was characterized by aspen forests found on upland, north-facing or lower slope positions as well as on more stabilized landforms. This community was found to be most widespread occurring community type in Manito Sandhills. The authors also documented a Populus tremuloides loam type, forests found on well to moderately well drained sandy loam to clay loam soils. Common species included Symphoricarpos occidentalis, Rubus 
strigosus, Amelanchier alnifolia, Rosa woodsii, Galium boreale, Thalictrum venulosum, Fragaria virginiana and Carex siccata.

Table 42. Similarity rating for Populus tremuloides / Amelanchier alnifolia - Rosa acicularis / Poa palustris community types documented outside Alberta.

\begin{tabular}{|l|c|l|}
\hline Similar Communities and Citations & $\begin{array}{l}\text { Similarity } \\
\text { Rating }\end{array}$ & \multicolumn{1}{|c|}{ Comments } \\
\hline $\begin{array}{l}\text { Populus tremuloides sand type (Thorpe and } \\
\text { Godwin 1993) }\end{array}$ & 2 & $\begin{array}{l}\text { This community has quite a similar species composition, though } \\
\text { different site conditions. }\end{array}$ \\
\hline $\begin{array}{l}\text { Populus tremuloides loam type (Thorpe and } \\
\text { Godwin 1993) }\end{array}$ & 1 & $\begin{array}{l}\text { This community has quite a similar species composition though } \\
\text { slightly different site conditions. }\end{array}$ \\
\hline $\begin{array}{l}\text { Populus tremuloides / Prunus virginiana Forest } \\
\text { (NatureServe 2003; MNHP 2002; Faber- }\end{array}$ & 2 & $\begin{array}{l}\text { This community has different site characteristics but is quite } \\
\text { similar floristically to that found in Wainwright. } \\
\text { Langendoen 2001; Marriott and Faber- }\end{array}$ \\
\hline $\begin{array}{l}\text { Populus tremuloides / Prunus virginiana } \\
\text { Woodland (NatureServe 2003; Faber- } \\
\text { Langendoen 2001; Schneider et al. 1997) }\end{array}$ & 2 & $\begin{array}{l}\text { This community has different site characteristics but is quite } \\
\text { similar floristically to that found in Wainwright.. }\end{array}$ \\
\hline $\begin{array}{l}\text { Populus tremuloides / Corylus cornuta Forest } \\
\text { (Faber-Langendoen 2001; Marriott and Faber- } \\
\text { Langendoen 2000;Schneider et al. 1997) }\end{array}$ & 2 & $\begin{array}{l}\text { This community has different site characteristics but shares } \\
\text { several floristic similarities to the Wainwright community. }\end{array}$ \\
\hline
\end{tabular}

A number of authors documented a Populus tremuloides / Prunus virginiana forest community type from the Rocky Mountains and Black Hills in the western United States (NatureServe 2003; Faber-Langendoen 2001; Marriott and Faber-Langendoen 2000a; Schneider et al. 1997). In the Black Hills, this community tended to occur along mesic valley bottoms where slopes varied from steep to gentle. While deciduous trees dominated the community, there a small component of evergreen trees Picea glauca (in the Black Hills) and Pinus ponderosa could occasionally be found. Common understorey species included Prunus virginiana, Amelanchier alnifolia, Ribes spp., and Symphoricarpos spp. Several authors also documented a Populus tremuloides / Prunus virginiana woodland community found in the north-central Great Plains of the United States and Canada Woodland (NatureServe 2003; Faber-Langendoen 2001; Schneider et al. 1997). In North Dakota, this community occurred on well-drained loam soils. The canopy was moderately dense to dense and was dominated by Populus tremuloides, although Fraxinus pennsylvanica may be a common associate. The shrub layer was typically very well developed and was dominated by Prunus virginiana. Other understorey species included Amelanchier alnifolia, Corylus spp., Rosa spp., and Symphoricarpos occidentalis. Aralia nudicaulis, Maianthemum stellatum, and Galium boreale may be found in the herbaceous layer. A Populus tremuloides / Corylus cornuta forest community type has been described from the midwest, where it is found in gently sloping to rolling topography in the northwest Great Plains and the Rocky Mountains and Black Hills ranges in the U.S. and southern Canada Forest (Faber-Langendoen 2001; Marriott and Faber-Langendoen 2000;Schneider et al. 1997). It is thought to extend from Colorado and South Dakota north to Saskatchewan. Populus tremuloides was the dominant tree although Betula papyrifera was common and may be codominant. Scattered Quercus macrocarpa, Fraxinus pennsylvanica and, in the Black Hills, Picea glauca or Pinus ponderosa occurred. There was a prominent understorey of shrubs and forbs with few graminoids. The shrub layer was dominated by Corylus cornuta although Amelanchier alnifolia, Mahonia repens, Prunus virginiana, Symphoricarpos spp., and Rubus idaeus may also be associated. In the western part of its range Spiraea betulifolia commonly occurred. The herbaceous layer was characterized by Aralia nudicaulis, Lathyrus ochroleucus, Maianthemum canadense, Galium triflorum, Maianthemum stellatum, Viola spp., and Sanicula marilandica. 
Many other Populus tremuloides-dominated community types have been documented outside of Alberta, however most do not share many site or floristic characteristics and thus have not been discussed.

\subsubsection{Preliminary Conservation Ranking of Populus tremuloides / Amelanchier alnifolia - Rosa acicularis / Poa palustris Community}

Preliminary Rank: S5

This community type was quite extensive in the Wainwright Dunes Ecological Reserve and was found on level sites where moisture was available. Communities with a similar floristic composition are common throughout Alberta and the Aspen Parkland and Great Plains in general (NatureServe 2003; Faber-Langendoen 2001; Marriott and FaberLangendoen 2000a; Meijer and Karpuk 1999; Schneider et al. 1997; Adams et al. 1997; Pearson Timberline 1993; Fehr 1982). While the communities described from Wainwright occur on a sandy substrate, this is not a restriction to the distribution of this community.

A preliminary rank of $\mathbf{S 5}$ is suggested for this community type, as it appears to be quite extensive. 


\subsection{Salix bebbiana / Festuca saximontana Association}

Beaked willow / Rocky Mountain sedge

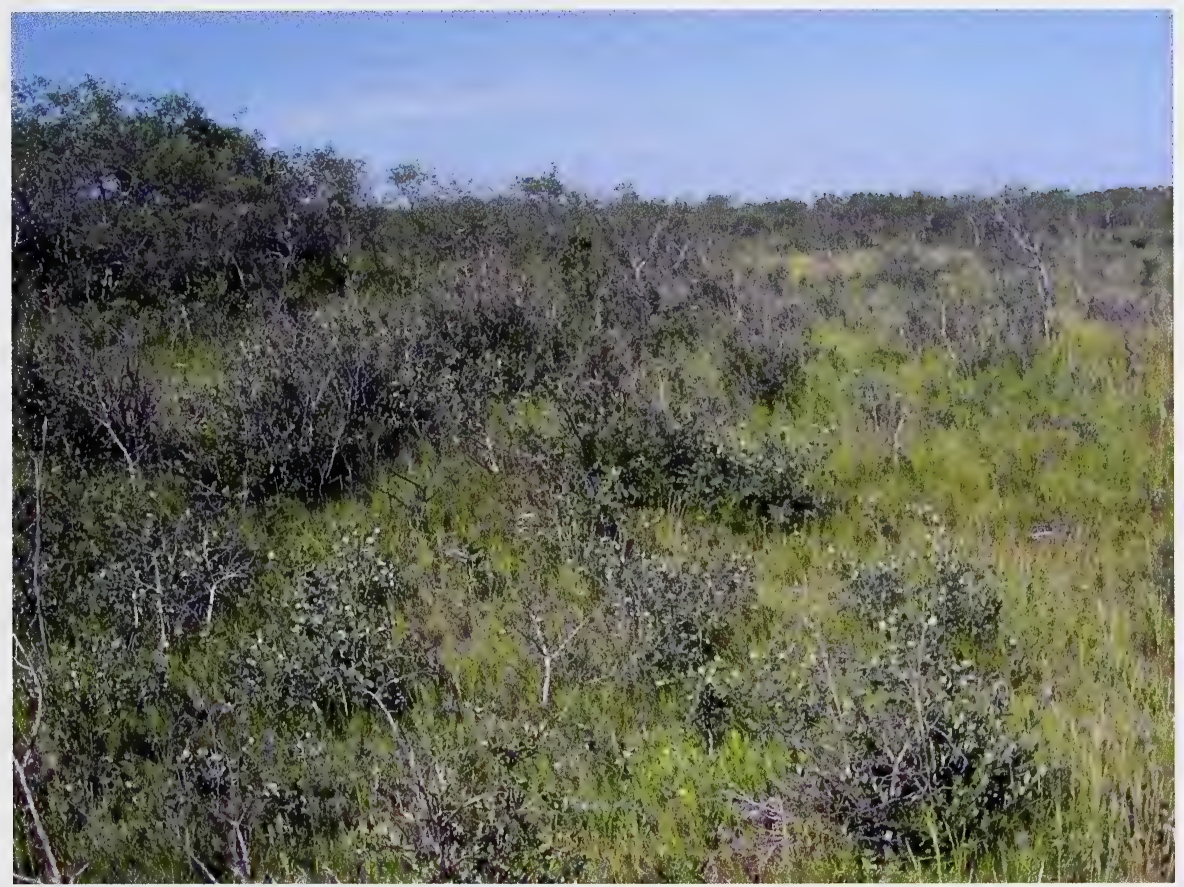

Plate 10. Salix bebbiana / Festuca saximontana community type (Beaked willow / Rocky Mountain sedge) Plot 30.

The Salix bebbiana / Festuca saximontana community type was not common or extensive. It was typically found in depressional locations in sand plains or occasionally in a depressional site between dunes. In all cases, a relatively open shrub cover dominated by Salix bebbiana characterized the community. Other shrub species were present, including young Populus tremuloides as well as Juniperus horizontalis and Arctostaphylos uva-ursi. Festuca saximontana was the dominant graminoid, although Koeleria macrantha was also found at each site sampled. Solidago missouriensis and Heuchera richardsonii were also relatively common, as was Cladina mitis. Table 43 summarizes the species composition, mean percent cover, standard error and species prominence for this community type. 
Table 43. Summary statistics for the Salix bebbiana / Festuca saximontana community type $(n=3)$.

\begin{tabular}{|c|c|c|c|c|}
\hline Species & $\begin{array}{c}\text { Mean } \% \\
\text { Cover }\end{array}$ & $\begin{array}{l}\text { Standard } \\
\text { Error }\end{array}$ & Presence & Prominence \\
\hline Salix bebbiana & 12.0 & 5.7 & 3 & 12.0 \\
\hline Festuca saximontana & 9.5 & 7.8 & 3 & 9.5 \\
\hline Koeleria macrantha & 7.7 & 3.7 & 3 & 7.7 \\
\hline Populus tremuloides & 6.3 & 3.0 & 3 & 6.3 \\
\hline Cladina mitis & 3.7 & 1.7 & 3 & 3.7 \\
\hline Solidago spathulata & 2.0 & 0.6 & 3 & 2.0 \\
\hline Heuchera richardsonii & 0.5 & 0.0 & 3 & 0.5 \\
\hline Carex siccata & 13.3 & 10.9 & 2 & 16.3 \\
\hline Juncus balticus & 6.8 & 6.6 & 2 & 8.4 \\
\hline Juniperus horizontalis & 2.0 & 1.5 & 2 & 2.4 \\
\hline Poa pratensis & 2.0 & 1.5 & 2 & 2.4 \\
\hline Comandra umbellata & 1.8 & 1.6 & 2 & 2.2 \\
\hline Arctostaphylos uva-ursi & 1.0 & 0.6 & 2 & 1.2 \\
\hline Artemisia ludoviciana & 0.5 & 0.3 & 2 & 0.6 \\
\hline Artemisia campestris & 10.0 & 10.0 & 1 & 17.3 \\
\hline Stipa comata & 5.0 & 5.0 & 1 & 8.7 \\
\hline Selaginella densa & 3.3 & 3.3 & 1 & 5.8 \\
\hline Calamovilfa longifolia & 2.3 & 2.3 & 1 & 4.0 \\
\hline Spirea alba & 2.3 & 2.3 & 1 & 4.0 \\
\hline Stipa spartea & 2.3 & 2.3 & 1 & 4.0 \\
\hline Bouteloua gracilis & 1.7 & 1.7 & 1 & 2.9 \\
\hline $\begin{array}{l}\text { Carex pensylvanica ssp. } \\
\text { heliophila }\end{array}$ & 1.7 & 1.7 & 1 & 2.9 \\
\hline Agrostis scabra & 0.7 & 0.7 & 1 & 1.2 \\
\hline
\end{tabular}

\begin{tabular}{|c|c|c|c|c|}
\hline Species & $\begin{array}{c}\text { Mean } \% \\
\text { Cover }\end{array}$ & $\begin{array}{l}\text { Standard } \\
\text { Error }\end{array}$ & Presence & Prominence \\
\hline $\begin{array}{l}\text { Schizachne } \\
\text { purpurescens }\end{array}$ & 0.7 & 0.7 & 1 & 1.2 \\
\hline Solidago missouriensis & 0.7 & 0.7 & 1 & 1.2 \\
\hline $\begin{array}{l}\text { Agropyron } \\
\text { dasystachyum }\end{array}$ & 0.3 & 0.3 & 1 & 0.6 \\
\hline Amelanchier alnifolia & 0.3 & 0.3 & 1 & 0.6 \\
\hline Anemone multifida & 0.3 & 0.3 & 1 & 0.6 \\
\hline Carex filifolia & 0.3 & 0.3 & 1 & 0.6 \\
\hline $\begin{array}{l}\text { Chenopodium } \\
\text { pratericola }\end{array}$ & 0.3 & 0.3 & 1 & 0.6 \\
\hline Rosa acicularis & 0.3 & 0.3 & 1 & 0.6 \\
\hline $\begin{array}{l}\text { Symphoricarpos } \\
\text { occidentalis }\end{array}$ & 0.3 & 0.3 & 1 & 0.6 \\
\hline Agoseris glauca & 0.2 & 0.2 & 1 & 0.3 \\
\hline Arabis holboellii & 0.2 & 0.2 & 1 & 0.3 \\
\hline Artemisia frigida & 0.2 & 0.2 & 1 & 0.3 \\
\hline Descurainia sophia & 0.2 & 0.2 & 1 & 0.3 \\
\hline Equisetum hymenale & 0.2 & 0.2 & 1 & 0.3 \\
\hline Erigeron glabellus & 0.2 & 0.2 & 1 & 0.3 \\
\hline Erysimum asperum & 0.2 & 0.2 & 1 & 0.3 \\
\hline Gaillardia aristata & 0.2 & 0.2 & 1 & 0.3 \\
\hline Gallium boreale & 0.2 & 0.2 & 1 & 0.3 \\
\hline Heterotheca villosa & 0.2 & 0.2 & 1 & 0.3 \\
\hline Lepidium densiflorum & 0.2 & 0.2 & 1 & 0.3 \\
\hline Opuntia fragilis & 0.2 & 0.2 & 1 & 0.3 \\
\hline Potentilla hippiana & 0.2 & 0.2 & 1 & 0.3 \\
\hline Rosa arkansana & 0.2 & 0.2 & 1 & 0.3 \\
\hline
\end{tabular}

This community was typically found in level to slightly depressional sites, with a straight to concave surface shape. The majority of sites had a relatively shallow but extensive accumulation of organic matter at the soils surface, although patches of exposed sand could occasionally be found. A summary of site data is provided in Table 44.

Table 44. Summary of site data for the Salix bebbiana / Festuca saximontana community type $(n=3)$.

\begin{tabular}{ccccccccc}
\hline Plot Elevation & Slope & Aspect & Drainage & $\begin{array}{c}\text { Site } \\
\text { Position }\end{array}$ & $\begin{array}{c}\text { Surface } \\
\text { Shape }\end{array}$ & $\begin{array}{c}\text { Moisture } \\
\text { Regime }\end{array}$ & $\begin{array}{c}\text { Nutrient } \\
\text { Regime }\end{array}$ \\
\hline 10 & 693 & 0 & $\mathrm{n} / \mathrm{a}$ & Well & Toe & Concave & Submesic & Medium \\
\hline 18 & 670 & 0 & $\mathrm{n} / \mathrm{a}$ & Well & Level & Straight & Subxeric & Poor \\
\hline 30 & 686 & 3 & 18 & Moderately Well & Toe & Straight & Submesic & Medium \\
\hline \hline
\end{tabular}




\subsubsection{Comparison of Salix bebbiana / Festuca saximontana Community to Literature}

There are few documented communities from Alberta that appear to be related to the community type observed in the Wainwright Dunes Ecological Reserve. A Salix bebbiana / Cornus stolonifera community type was reported from throughout the Grassland Natural Region as well as in the Central Parkland, Foothills Parkland, Montane, and Lower Foothills subregions Wainwright (Thompson and Hansen 2002). It was typically found on alluvial terraces with moist to wet soils. Salix bebbiana typically formed the tall shrub layer with Cornus stolonifera in the understorey. Furthermore, a Salix bebbiana / Rubus ideaus / Geranium richardsonii community has been described in the Foothills Parkland subregion where it typically occurred on moderately well to imperfectly drained sites (Allen 2003; Wallis 1980). It was also noted to have a significant tall herb component. Table 45 summarizes the Alberta community types and their similarity to the community found in the Wainwright Dunes Ecological Reserve.

Table 45. Similarity rating for Salix bebbiana / Festuca saximontana community types documented within Alberta.

\begin{tabular}{|l|c|l|}
\hline \multicolumn{1}{|c|}{$\begin{array}{c}\text { Similar Communities and } \\
\text { Citations }\end{array}$} & $\begin{array}{c}\text { Similarity } \\
\text { Rating }\end{array}$ & \multicolumn{1}{c|}{ Comments } \\
\hline $\begin{array}{l}\text { Salix bebbiana / Cornus stolonifera } \\
\text { (Thompson and Hansen 2002) }\end{array}$ & 3 & $\begin{array}{l}\text { This community has different site characteristics and a } \\
\text { different floristic composition than that found in Wainwright. }\end{array}$ \\
\hline $\begin{array}{l}\text { Salix bebbiana / Rubus ideaus / Geranium } \\
\text { richardsonii (Wallis 1980) }\end{array}$ & 3 & $\begin{array}{l}\text { This community is very different floristically than that found in } \\
\text { Wainwright. }\end{array}$ \\
\hline
\end{tabular}

Several related community types have been recorded outside of Alberta, which are listed in Table 46. Hansen et al. (1995) described a Salix bebbiana community from Montana. This riparian community was documented from alluvial terraces and adjacent to seeps and springs, from low to moderately high elevations in the mountains, mountain valleys and foothills. Common species included: Poa pratensis, Phleum pratensis, Agrostis stolonifera and Solidago canadensis. Soil textures were quite variable, ranging from clay loam to sandy loam. Another Salix bebbiana riparian community has been documented from the Black Hills, where it occurs in both South Dakota and Wyoming (Marriott and Faber-Langendoen 2000). Shrub cover was noted to be somewhat patchy, and some associated species included Betula occidentalis, Cornus stolonifera, Salix exigua, Symphoricarpos occidentalis, and Pentaphylloides floribunda with quite a variable herbaceous layer.

NatureServe (2003) described a Salix bebbiana Temporarily Flooded Shrubland Alliance. This shrubland was found in the montane regions and western plains of the United States, ranging from South Dakota and Montana south to New Mexico. This community was known to be flooded for short periods during the year, usually near lowgradient streams. The water table was well below the soil surface for the majority of the growing season. However, periodically water is at the surface. These communities were typically dominated by a dense growth of shrubs. The most abundant species are Salix bebbiana, Salix scouleriana, and Salix lucida ssp. caudata. The graminoid and herbaceous layer contained Scirpus spp., Carex spp., Triglochin palustris, Calamagrostis canadensis, and Equisetum as well as Gentiana strictiflora, Prunella vulgaris, Pyrola asarifolia, Ranunculus macounii, Sanicula marilandica, Viola canadensis, Vicia americana and Zizia aptera. 
Table 46. Similarity rating for Salix bebbiana / Festuca saximontana community types documented outside Alberta.

\begin{tabular}{|l|c|l|}
\hline \multicolumn{1}{|c|}{$\begin{array}{c}\text { Similar Communities and } \\
\text { Citations }\end{array}$} & $\begin{array}{c}\text { Similarity } \\
\text { Rating }\end{array}$ & \multicolumn{1}{c|}{ Comments } \\
\hline Salix bebbiana (Hansen et al. 1995) & 3 & $\begin{array}{l}\text { This community is quite different in terms of site characteristics and } \\
\text { floristic composition than that found in Wainwright. }\end{array}$ \\
\hline $\begin{array}{l}\text { Salix bebbiana (Marriott and Faber- } \\
\text { Langendoen 2000) }\end{array}$ & 3 & $\begin{array}{l}\text { This community is quite different in terms of site characteristics and } \\
\text { floristic composition than that found in Wainwright. }\end{array}$ \\
\hline $\begin{array}{l}\text { Salix bebbiana Temporarily Flooded } \\
\text { Shrubland Alliance (NatureServe 2003) }\end{array}$ & 3 & $\begin{array}{l}\text { This community has different floristic and site conditions than that } \\
\text { observed at Wainwright. }\end{array}$ \\
\hline $\begin{array}{l}\text { Salix bebbiana / Mesic Graminoids } \\
\text { Shrubland (NatureServe 2003) }\end{array}$ & $?(3)$ & $\begin{array}{l}\text { This community is described as a temporarily flooded deciduous } \\
\text { shrubland that is found in Idaho and Utah. Unfortunately, no further } \\
\text { information is provided to make an assessment of similarity. }\end{array}$ \\
\hline Salix bebbiana Shrubland (MNHP 2002) & $?(3)$ & $\begin{array}{l}\text { Listed as G3Q / S3? for Montana. No description given thus no } \\
\text { similarity assessment could be made. }\end{array}$ \\
\hline Salix bebbiana Shrubland (CNHP 2001) & $?(3)$ & $\begin{array}{l}\text { This type is listed as a natural wetland plant community for Colorado, } \\
\text { but no description given thus no assessment of similarity could be done. } \\
\text { Ranked G3? / S2 }\end{array}$ \\
\hline Salix bebbiana Shrubland (Rust 1997) & $?(3)$ & $\begin{array}{l}\text { Listed as a natural plant community for Idaho. No description given thus } \\
\text { no similarity assessment could be made. }\end{array}$ \\
\hline
\end{tabular}

NatureServe (2003) also documented a Salix bebbiana / Mesic Graminoids Shrubland. This community was described as a temporarily flooded deciduous shrubland that is found in Idaho and Utah community type. Montana, Idaho and Colorado all document Salix bebbiana shrublands as native community types, but unfortunately no further information is provided (MNHP 2002; Rust 1997; CNHP 2001).

\subsubsection{Preliminary Conservation Ranking of Salix bebbiana / Festuca saximontana Community}

Preliminary Rank: SU

This community was not common or extensive in the Wainwright Dunes Ecological Reserve. It was typically found in depressional locations in sand plains or occasionally in depressional sites between dunes. The majority of the Salix bebbiana-dominated communities recorded in the literature were noted to be riparian communities that were temporarily or seasonally flooded. ANHIC (Allen 2003) currently tracks two Salix bebbiana communities, however, both are quite different than that found at the Wainwright Dunes Ecological Reserve. This Salix bebbiana-dominated community found in the Wainwright Dunes Ecological Reserve may represent a transitional or ecotonal position between other community types. While the three survey plots did share a number of similar prominent plant species, there was substantial variability in the floristic composition of each survey site.

As such a preliminary rank of $\mathbf{S U}$ is suggested for this community type. Additional sampling from sand dune and sand plain habitats both within the Wainwright Dunes Ecological Reserve and from other areas in Alberta could help to clarify the validity of the community type and determining its geographic extent. 


\subsection{Salix petiolaris / Calamagrostis canadensis Association}

Basket willow / bluejoint

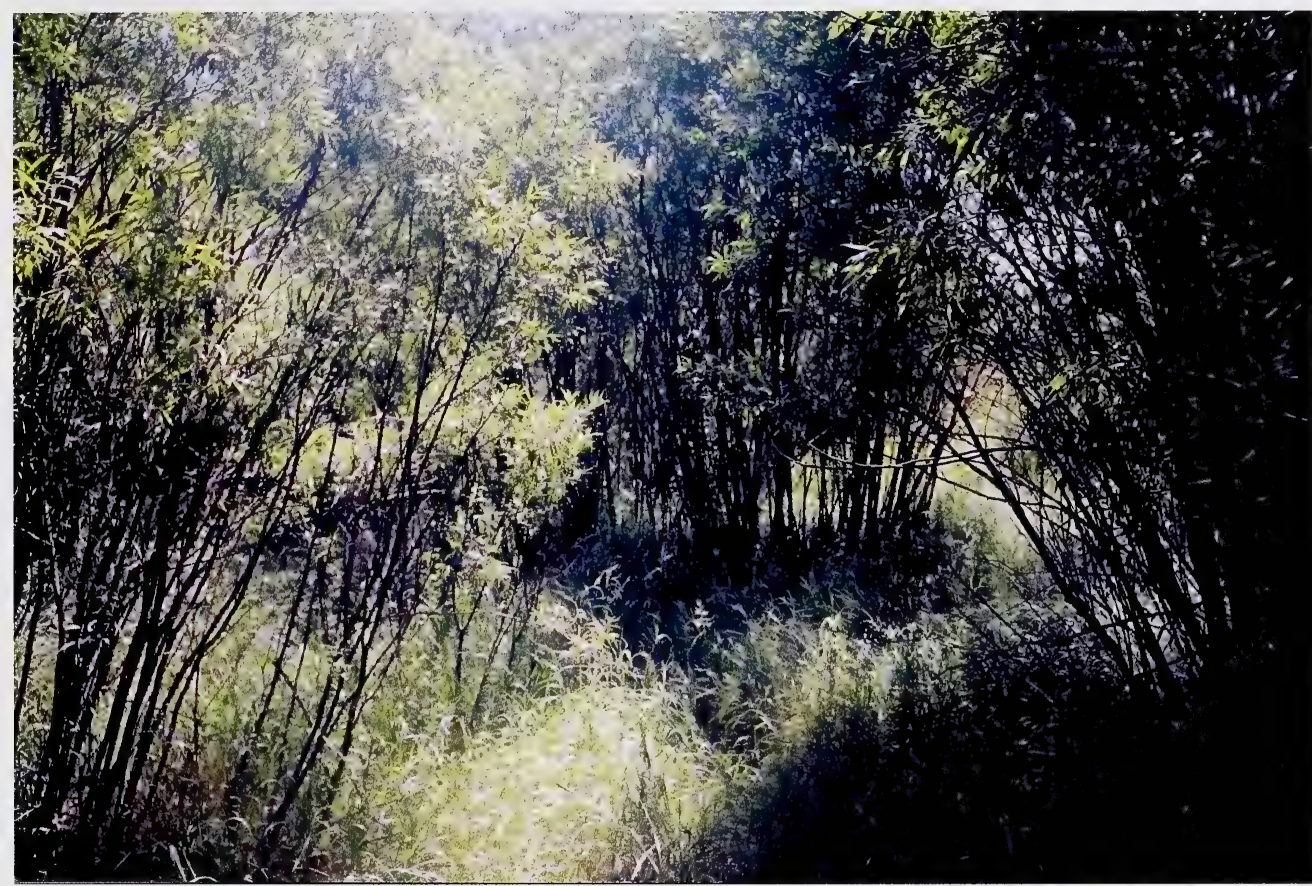

Plate 11. Salix petiolaris / Calamagrostis canadensis community type (Basket willow / bluejoint) Plot 12.

The Salix petiolaris / Calamagrostis canadensis community type formed relatively large units, although their distribution was quite limited. It was typically found in lower landscape positions in sand plains or at the base of large dunes where seasonal drainage provided ephemeral moisture. Tall thickets of Salix petiolaris dominated this community, although the occasional Betula papyrifera was found in all sample sites. Cornus stolonifera, Rubus idaeus, Ribes oxyacanthoides and Lonicera dioica were also found at the majority of sites. While forbs did occur, graminoids dominated the ground cover with Calamagrostis canadensis being the dominant. Poa palustris, Poa pratensis and several species of Carex were also found, but with lower percent covers. Common forbs included Rubus pubescens, Galium triflorum, Cornus canadensis, Epilobium angustifolium and Scutellaria galericulata. Table 47 summarizes the species composition, mean percent cover, standard error and species prominence for this community type. 
Table 47. Summary statistics for the Salix petiolaris / Calamagrostis canadensis community type $(n=3)$.

\begin{tabular}{lcccc}
\hline \multicolumn{1}{c}{ Species } & $\begin{array}{c}\text { Mean } \% \\
\text { Cover }\end{array}$ & $\begin{array}{c}\text { Standard } \\
\text { Error }\end{array}$ & Presence Prominence \\
\hline Salix petiolaris & 58.3 & 3.2 & 3 & 58.3 \\
\hline $\begin{array}{l}\text { Calamagrostis } \\
\text { canadensis }\end{array}$ & 56.7 & 3.3 & 3 & 56.7 \\
\hline Poa palustris & 6.7 & 1.7 & 3 & 6.7 \\
\hline Betula papyrifera & 4.0 & 2.1 & 3 & 4.0 \\
\hline Cornus stolonifera & 2.8 & 2.1 & 3 & 2.8 \\
\hline Rubus pubescens & 2.7 & 1.2 & 3 & 2.7 \\
\hline Gallium triflorum & 0.8 & 0.2 & 3 & 0.8 \\
\hline Rubus idaeus & 5.3 & 4.8 & 2 & 6.5 \\
\hline Poa pratensis & 2.3 & 1.5 & 2 & 2.9 \\
\hline $\begin{array}{l}\text { Ribes } \\
\text { oxyacanthoides }\end{array}$ & 1.7 & 1.2 & 2 & 2.0 \\
\hline Cornus canadensis & 0.8 & 0.6 & 2 & 1.0 \\
\hline Fragaria virginiana & 0.7 & 0.3 & 2 & 0.8 \\
\hline Bromus inermis & 0.5 & 0.3 & 2 & 0.6 \\
\hline Epilobium & & 0.3 & 2 & 0.6 \\
\hline angustifolium & 0.5 & & & \\
\hline
\end{tabular}

\begin{tabular}{|c|c|c|c|c|}
\hline Species & $\begin{array}{c}\text { Mean } \% \text {. } \\
\text { Cover }\end{array}$ & $\begin{array}{l}\text { Standard } \\
\text { Error }\end{array}$ & Presence & Prominence \\
\hline $\begin{array}{l}\text { Scutellaria } \\
\text { galericulata }\end{array}$ & 0.5 & 0.3 & 2 & 0.6 \\
\hline Lonicera dioica & 0.3 & 0.2 & 2 & 0.4 \\
\hline Viola adunca & 0.3 & 0.2 & 2 & 0.4 \\
\hline Viola canadensis & 0.3 & 0.2 & 2 & 0.4 \\
\hline Rosa acicularis & 3.3 & 3.3 & 1 & 5.8 \\
\hline $\begin{array}{l}\text { Schizachne } \\
\text { purpurescens }\end{array}$ & 0.7 & 0.7 & 1 & 1.2 \\
\hline Ribes triste & 0.5 & 0.5 & 1 & 0.9 \\
\hline Carex spp. & 0.3 & 0.3 & 1 & 0.6 \\
\hline $\begin{array}{l}\text { Populus } \\
\text { tremuloides }\end{array}$ & 0.3 & 0.3 & 1 & 0.6 \\
\hline Pyrola asarifolia & 0.3 & 0.3 & 1 & 0.6 \\
\hline $\begin{array}{l}\text { Symphoricarpos } \\
\text { occidentalis }\end{array}$ & 0.3 & 0.3 & 1 & 0.6 \\
\hline $\begin{array}{l}\text { Amelanchier } \\
\text { alnifolia }\end{array}$ & 0.2 & 0.2 & 1 & 0.3 \\
\hline Prunus virginiana & 0.2 & 0.2 & 1 & 0.3 \\
\hline
\end{tabular}

This community was typically found in an imperfectly drained, depressional landscape position. Due to the presence of seepage or ephemeral stream flow, these communities were considered to have a subhygric to hygric moisture regime and a rich (permesotrophic) nutrient regime. A summary of site data is provided in Table 48.

Table 48. Summary of site data for the Salix petiolaris / Calamagrostis canadensis community type $(n=2)$.

\begin{tabular}{ccccccccc}
\hline Plot Elevation & Slope & Aspect & Drainage & $\begin{array}{c}\text { Site } \\
\text { Position }\end{array}$ & $\begin{array}{c}\text { Surface } \\
\text { Shape }\end{array}$ & $\begin{array}{c}\text { Moisture } \\
\text { Regime }\end{array}$ & $\begin{array}{c}\text { Nutrient } \\
\text { Regime }\end{array}$ \\
\hline 12 & 682 & 0 & n/a & Imperfectly & Depression & Straight & Hygric & Rich \\
\hline 20 & 670 & 0 & $\mathrm{n} / \mathrm{a}$ & Imperfectly & Depression & Straight & Subhygric & Rich \\
\hline 39 & 682 & 0 & $\mathrm{n} / \mathrm{a}$ & Imperfectly & Depression & Straight & Subhygric & Rich \\
\hline \hline
\end{tabular}

\subsubsection{Comparison of Salix petiolaris / Calamagrostis canadensis Community to Literature}

Previous studies in the Wainwright Dunes Ecological Reserve and elsewhere in Alberta have identified related community types, and are summarized in Table 49. Fehr described a "willow community type" in a 1984 survey of the Wainwright Dunes Ecological Reserve. This community was noted to be found in areas with a mesic to subhydric moisture regime that were poorly to imperfectly drained. Tree layers were not commonly found but when they were they had a low percent cover. Tall shrub layer cover averaged about $65 \%$ with willow species being dominant. Important willow species included Salix maccalliana, S. myrtillifolia, S. petiolaris and S. planifolia. Calamagrostis canadensis was not noted to be an important graminoid species. While site 
characteristics are quite similar, the species composition seems somewhat different than those found in this field survey. A Salix petiolaris / (low shrubs and herbs) community has been described from two locations in the Central Parkland by different authors (Wheatley and Bentz 2002; Fehr 1982; Wroe 1971). The community was generally found around sloughs, moist depressions and was limited to moist areas with rolling topography. It had been found on sites with mesic to hydric moisture regimes that were typically moderately well to poorly drained. Associated species included Populus tremuloides, Salix lutea, Populus balsamifera, Rosa woodsii, Amelanchier alnifolia, Poa palustris, Calamagrostis spp. Carex rostrata and Carex atherodes. A Salix petiolaris Salix planifolia / Carex utriculata community was noted to occur around flooded areas near Onoway (Wheatley and Bentz 2002; Griffiths and Griffiths 1987). The community was found in a flooded location, where Salix pyrifolia was rare or not found at all. Other species noted to occur included Carex aquatilis, Glyceria grandis, Scirpus microcarpus, Galium trifidum, Lysmachia thrysiflora, Bidens cernua, Lemna minor and Calamagrostis canadensis. Finally, a Salix petiolaris / Juncus balticus community was found in the Central Parkland near Lister Lake. It is described as having a high water table, which limited the establishment of Populus balsamifera. Associated species included Juncus balticus, Calamagrostis stricta, and Poa pratensis.

Table 49. Similarity rating for Salix petiolaris / Calamagrostis canadensis community type documented within Alberta.

\begin{tabular}{|c|c|c|}
\hline $\begin{array}{l}\text { Similar Communities and } \\
\text { Citations }\end{array}$ & $\begin{array}{l}\text { Similarity } \\
\text { Rating }\end{array}$ & Comments \\
\hline Willow community type (Fehr 1984) & 2 & $\begin{array}{l}\text { While site characteristics are quite similar, the species composition } \\
\text { seems somewhat different than those found in this field survey. Fehr may } \\
\text { have sampled and included sites that were not visited in this field survey. }\end{array}$ \\
\hline $\begin{array}{l}\text { Salix petiolaris / (low shrubs and } \\
\text { herbs) (Fehr 1982; Wroe 1971) }\end{array}$ & 2 & $\begin{array}{l}\text { Some of the species in this community are similar to those observed at } \\
\text { Wainwright, and generally the site characteristics match as well. } \\
\text { However, some of the associated species are significantly different. }\end{array}$ \\
\hline $\begin{array}{l}\text { Salix petiolaris - Salix planifolia / } \\
\text { Carex utriculata (Wheatley and Bentz } \\
\text { 2002; Griffiths and Griffiths 1987) }\end{array}$ & 3 & $\begin{array}{l}\text { While the dominant species in this community is analogous to that found } \\
\text { in Wainwright, the site conditions appear to be much wetter. The } \\
\text { Wainwright community was found in lowland positions, but along } \\
\text { ephemeral drainages. }\end{array}$ \\
\hline $\begin{array}{l}\text { Salix petiolaris / Juncus balticus } \\
\text { (Wheatley and Bentz 2002; Griffiths } \\
\text { 1996) }\end{array}$ & 3 & $\begin{array}{l}\text { This community is substantially different in terms of site characteristics } \\
\text { and associated species. }\end{array}$ \\
\hline
\end{tabular}

Several related community types have been recorded outside of Alberta and are noted in Table 50. A Salix petiolaris - (Betula pumila) / Spartina pectinata - Carex lanuginosa community is described from Manitoba and Minnesota (Schneider et al. 1997). Unfortunately, no further information is provided. Furthermore, Schneider et al. (1997) described a Salix petiolaris / Carex interior - Thelypteris palustris community known to occur from Nebraska and South Dakota, in sandhills habitats.

NatureServe (2003) documented a Salix petiolaris - (Betula pumila) / Spartina pectinata Carex pellita wet brush prairie community type from the aspen parkland region of the upper midwestern United States and Canada, particularly in western Minnesota and southeastern Manitoba. This community typically occurred on level, poorly drained sites with from loamy fine sand to sandy clay loam soils. 
Table 50. Similarity rating for Salix petiolaris / Calamagrostis canadensis community type documented outside Alberta.

\begin{tabular}{|l|c|c|}
\hline $\begin{array}{c}\text { Similar Communities and } \\
\text { Citations }\end{array}$ & $\begin{array}{c}\text { Similarity } \\
\text { Rating }\end{array}$ & Comments \\
\hline $\begin{array}{l}\text { Salix petiolaris - (Betula pumila) / } \\
\text { Spartina pectinata - Carex lanuginosa } \\
\text { (Schneider et al. 1997) }\end{array}$ & $?(3)$ & $\begin{array}{l}\text { No description provided, although it's noted to occur in Manitoba and } \\
\text { Minnesota. The authors suggest a conservation rating of G?. No } \\
\text { description of community type is given, thus cannot assess similarity. } \\
\text { However, superficially it appears to be floristically quite different. }\end{array}$ \\
\hline $\begin{array}{l}\text { Salix petiolaris / Carex interior- } \\
\text { Thelypteris palustris (Schneider et al. } \\
\text { 1997) }\end{array}$ & $?(3)$ & $\begin{array}{l}\text { No description provided, although it's noted to occur in Nebraska and } \\
\text { South Dakota, in sandhills. The authors suggest a conservation rating } \\
\text { of G2. No description of community type is given, thus cannot assess } \\
\text { similarity. However, superficially it appears to be floristically quite } \\
\text { different though it occurs in sandhills habitats. }\end{array}$ \\
\hline $\begin{array}{l}\text { Salix petiolaris - (Betula pumila)/ } \\
\text { Spartina pectinata - Carex pellita } \\
\text { Shrubland (NatureServe 2003) }\end{array}$ & 2 & $\begin{array}{l}\text { This community shares many floristic and site conditions as the } \\
\text { community in Wainwright. }\end{array}$ \\
\hline
\end{tabular}

The vegetation consisted of clumps or thickets of low shrubs in a graminoid matrix of wet prairie vegetation. Some of the dominant graminoids included Spartina pectinata, Calamagrostis stricta, Calamagrostis canadensis, Andropogon gerardii, and Muhlenbergia richardsonii. Common sedges included Carex buxbaumii, Carex pellita, Carex sartwellii and Carex tetanica. Other shrubs included Pentaphylloides floribunda), Salix discolor and Salix petiolaris. Betula pumila and Spiraea alba was occasionally common in certain areas. Scattered saplings, or groves of Populus tremuloides and Populus balsamifera were noted to occur.

\subsubsection{Preliminary Conservation Ranking of Salix petiolaris / Calamagrostis canadensis Community}

Preliminary Rank: SU

This community type formed relatively large patches in the Wainwright Dunes Ecological Reserve, however it had a limited distribution. It was typically found in lower landscape positions in sand plains or at the base of large dunes where seasonal drainage provided ephemeral moisture. There have been several reports of Salix petiolaris-dominated and general Salix spp. dominated communities, within Alberta and in other jurisdictions (NatureServe 2003; Schneider et al. 1997; Griffiths 1996; Griffiths and Griffiths 1987; Fehr 1982; Wroe 1971). Wheatley and Bentz (2002) assigned a preliminary rank of S5 for Salix petiolaris dominated communities in the Central Parkland. However, the floristic composition of all these descriptions vary from that found in the Wainwright Dunes Ecological Reserve. Many of the community descriptions that could be found from within and outside Alberta were too general to provide sufficient information for a conclusive conservation ranking.

As such a preliminary rank of SU is suggested for this community type. Additional sampling in sand dune and sand plain habitats outside of the Wainwright Dunes Ecological Reserve may help to clarify the status and geographic extent of this community type. 


\subsection{Stipa comata - Artemisia frigida - Selaginella densa Association}

Needle-and-thread - pasture sagewort - prairie selaginella

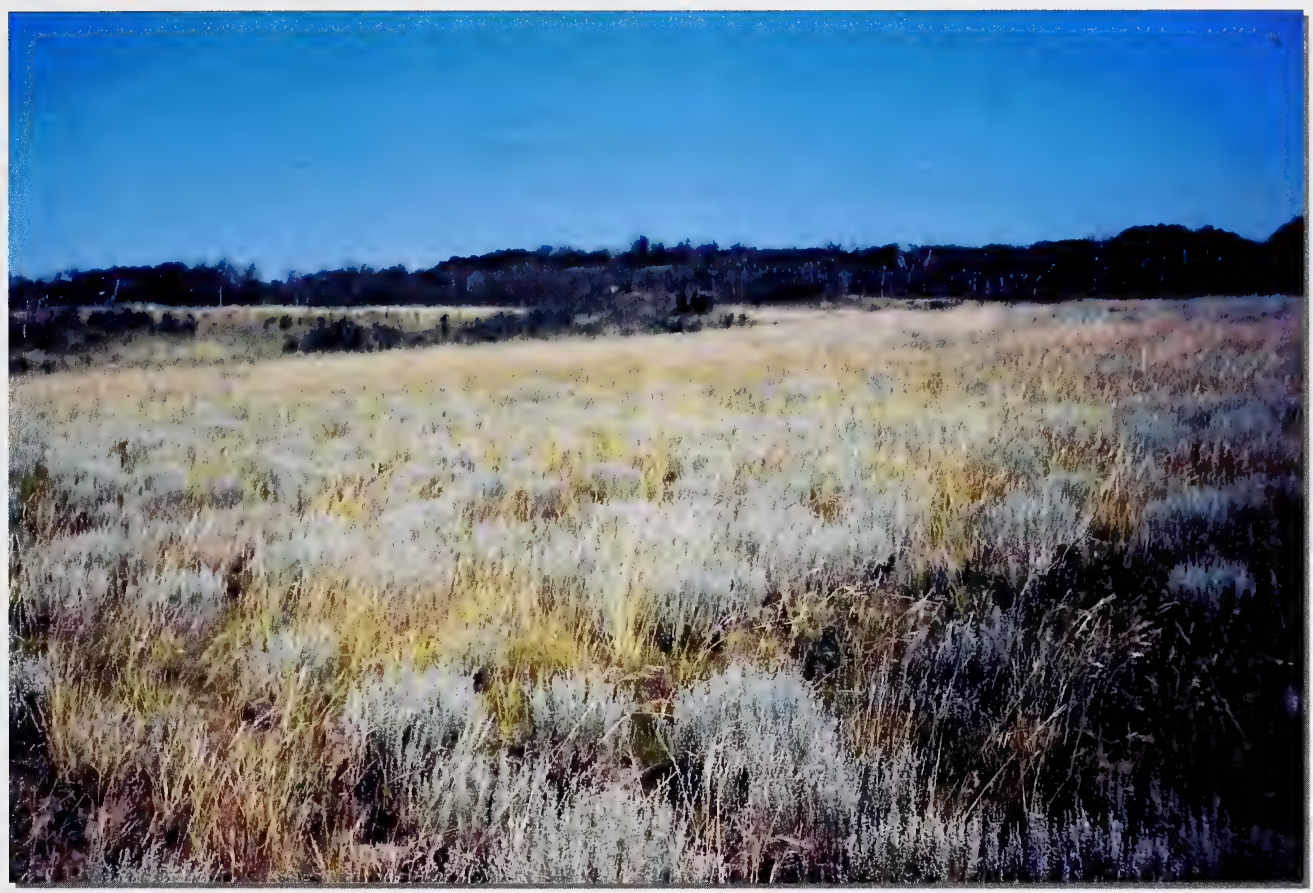

Plate 12. Stipa comata - Artemisia frigida - Selaginella densa community type (Needleand-thread - pasture sagewort - prairie selaginella) Plot 3.

The Stipa comata - Artemisia frigida - Selaginella densa community type was very extensive in the Wainwright Dunes Ecological Reserve, occurring on generally level to gently sloping sand plains. Graminoids were the dominant lifeform, with Stipa comata being the most prevalent species. Other common graminoids included Bouteloua gracilis, Koeleria macrantha, Stipa spartea, Carex siccata, and Calamovilfa longifolia. Artemisia frigida was the dominant forb species, although Selaginella densa, Heterotheca villosa, Artemisia ludoviciana and Potentilla hippiana were also quite common. Several low shrub species were commonly encountered, including Juniperus horizontalis, Prunus virginiana and Rosa arkansana, although with relatively low percent covers. Table 51 summarizes the species composition, mean percent cover, standard error and species prominence for this community type. 
Table 51. Summary statistics for the Stipa comata - Artemisia frigida - Selaginella densa community type $(n=4)$

\begin{tabular}{|c|c|c|c|c|}
\hline Species & $\begin{array}{l}\text { Mean } \% \\
\text { Cover }\end{array}$ & $\begin{array}{l}\text { Standard } \\
\text { Error }\end{array}$ & Presence & Prominence \\
\hline Stipa comata & 28.8 & 10.3 & 4 & 28.8 \\
\hline Artemisia frigida & 16.0 & 5.6 & 4 & 16.0 \\
\hline Selaginella densa & 10.0 & 2.0 & 4 & 10.0 \\
\hline Bouteloua gracilis & 6.8 & 2.0 & 4 & 6.8 \\
\hline Cladina mitis & 6.0 & 1.7 & 4 & 6.0 \\
\hline Koeleria macrantha & 6.0 & 0.6 & 4 & 6.0 \\
\hline $\begin{array}{l}\text { Juniperus } \\
\text { horizontalis }\end{array}$ & 4.0 & 1.0 & 4 & 4.0 \\
\hline Heterotheca villosa & 1.9 & 1.0 & 4 & 1.9 \\
\hline Stipa spartea & 8.0 & 4.1 & 3 & 9.2 \\
\hline Carex siccata & 6.3 & 2.4 & 3 & 7.2 \\
\hline $\begin{array}{l}\text { Calamovilfa } \\
\text { longifolia }\end{array}$ & 5.3 & 3.4 & 3 & 6.1 \\
\hline $\begin{array}{l}\text { Artemisia } \\
\text { ludoviciana }\end{array}$ & 1.9 & 1.1 & 3 & 2.2 \\
\hline Potentilla hippiana & 1.1 & 0.5 & 3 & 1.3 \\
\hline Agoseris glauca & 0.7 & 0.5 & 3 & 0.8 \\
\hline $\begin{array}{l}\text { Lepidium } \\
\text { densiflorum }\end{array}$ & 0.5 & 0.2 & 3 & 0.6 \\
\hline Prunus virginiana & 3.5 & 2.4 & 2 & 4.9 \\
\hline Rosa arkansana & 1.0 & 0.7 & 2 & 1.4 \\
\hline Anemone patens & 0.6 & 0.5 & 2 & 0.9 \\
\hline Erysimum asperum & 0.6 & 0.5 & 2 & 0.9 \\
\hline $\begin{array}{l}\text { Antennaria } \\
\text { parvifolia }\end{array}$ & 0.5 & 0.5 & 2 & 0.7 \\
\hline
\end{tabular}

\begin{tabular}{|c|c|c|c|c|}
\hline Species - & $\begin{array}{c}\text { Mean } \% \\
\text { Cover }\end{array}$ & $\begin{array}{l}\text { Standard } \\
\text { Error }\end{array}$ & Presence & Prominence \\
\hline Geum triflorum & 0.5 & 0.3 & 2 & 0.7 \\
\hline $\begin{array}{l}\text { Chamaerhodos } \\
\text { erecta }\end{array}$ & 0.4 & 0.2 & 2 & 0.5 \\
\hline $\begin{array}{l}\text { Comandra } \\
\text { umbellata }\end{array}$ & 0.4 & 0.2 & 2 & 0.5 \\
\hline Gaillardia aristata & 0.4 & 0.2 & 2 & 0.5 \\
\hline $\begin{array}{l}\text { Artemisia } \\
\text { campestris }\end{array}$ & 0.3 & 0.1 & 2 & 0.4 \\
\hline Gaura coccinea & 0.3 & 0.1 & 2 & 0.4 \\
\hline Descurainia sophia & 0.2 & 0.1 & 2 & 0.2 \\
\hline $\begin{array}{l}\text { Carex pensylvanica } \\
\text { ssp. heliophila }\end{array}$ & 1.3 & 1.3 & 1 & 2.5 \\
\hline $\begin{array}{l}\text { Solidago } \\
\text { missouriensis }\end{array}$ & 1.3 & 1.3 & 1 & 2.5 \\
\hline Carex filifolia & 0.5 & 0.5 & 1 & 1.0 \\
\hline $\begin{array}{l}\text { Arctostaphylos uva- } \\
\text { ursi }\end{array}$ & 0.3 & 0.3 & 1 & 0.5 \\
\hline $\begin{array}{l}\text { Chenopodium } \\
\text { pratericola }\end{array}$ & 0.3 & 0.3 & 1 & 0.5 \\
\hline Elymus candensis & 0.3 & 0.3 & 1 & 0.5 \\
\hline Gallium boreale & 0.3 & 0.3 & 1 & 0.5 \\
\hline $\begin{array}{l}\text { Thermopsis } \\
\text { rhombifolia }\end{array}$ & 0.3 & 0.3 & 1 & 0.5 \\
\hline $\begin{array}{l}\text { Equisetum } \\
\text { hymenale }\end{array}$ & 0.1 & 0.1 & 1 & 0.3 \\
\hline Hackelia americana & 0.1 & 0.1 & 1 & 0.3 \\
\hline Juncus balticus & 0.1 & 0.1 & 1 & 0.3 \\
\hline Poa interior & 0.1 & 0.1 & 1 & 0.3 \\
\hline $\begin{array}{l}\text { Populus } \\
\text { tremuloides }\end{array}$ & 0.1 & 0.1 & 1 & 0.3 \\
\hline
\end{tabular}

This community was typically found on level to gently sloping sand plains that were rapidly drained. Most sites sampled had a shallow but consistent accumulation of organic matter on the soil surface, with typically no greater than $1 \%$ exposed sand at the surface. A summary of site data is provided in Table 52.

Table 52. Summary of site data for the Stipa comata - Artemisia frigida - Selaginella densa community type $(n=4)$.

\begin{tabular}{ccccccccc}
\hline Plot Elevation & Slope & Aspect & Drainage & Site Position & $\begin{array}{c}\text { Surface } \\
\text { Shape }\end{array}$ & $\begin{array}{c}\text { Moisture } \\
\text { Regime }\end{array}$ & $\begin{array}{c}\text { Nutrient } \\
\text { Regime }\end{array}$ \\
\hline 3 & 695 & 0 & n/a & Rapidly & Level & Straight & Xeric & Poor \\
\hline 8 & 687 & 3 & 20 & Rapidly & Lower Slope & Straight & Subxeric & Poor \\
\hline 9 & 696 & 12 & 188 & Rapidly & Upper Slope & Convex & Subxeric & Poor \\
\hline 40 & 687 & 11 & 196 & Well & Middle Slope & Concave & Subxeric & Poor \\
\hline \hline
\end{tabular}




\subsubsection{Comparison of Stipa comata - Artemisia frigida - Selaginella densa Community to Literature}

Previous studies in the Wainwright Dunes Ecological Reserve and elsewhere in Alberta have identified related community types and these are listed in Table 53. Fehr described a Calamovilfa longifolia - Artemisia frigida - Koeleria macrantha - Festuca saximontana I Selaginella densa community type during a 1984 survey (Wheatley and Bentz 2002; Fehr 1984). This community was found in numerous sites typically on xeric to subxeric, rapidly drained sand flats. Dominant species included Calamovilfa longifolia, Artemisia frigida, Koeleria cristata, Festuca saximontana, and Festuca scabrella. The canopy cover of Selaginella densa averaged $28 \%$. The herb-dwarf shrub layer averaged $56 \%$, but could range from $40-70 \%$.

A Stipa comata - Koeleria macrantha - Agropyron smithii community type has been described from the Central Parkland subregion, from the Dillberry Lake region (Meijer and Karpuk 1999). This community was found on stabilized dune areas with little sign of current erosion or soil formation. It typically occurred on southwest facing slopes that were rapidly drained and had a subxeric moisture regime. Other species found in this community included Solidago missouriensis, Thermopsis rhombifolia, Calamovilfa longifolia, and Agropyron trachycaulum. An Artemisia frigida / Koeleria macrantha Carex obtusata community was also described from the same study area (Meijer and Karpuk 1999). While a detailed description of the community is not provided, the authors noted that it was typically found on south facing, glaciofluvial slopes. Its moisture regime was xeric to very xeric, and it was very rapidly drained. Associated species included Symphoricarpos occidentalis, Heterotheca villosa, Thermopsis rhombifolia and Agropyron trachycaulum. Meijer and Karpuk (1999) also noted a Stipa comata Koeleria macrantha - Agropyron trachycaulum - Carex obtusata community type found on south-facing slopes and flat uplands in hummocky glaciofluvial terrain. Associated species included Artemisia frigida, Petalostemon purpureum, Heuchera richardsonii, Calamovilfa longifolia, Poa sandbergii and Festuca hallii. This community was noted to be distinguished from similar eolian communities by the presence of Carex obtusata.

Adams et al. (1997) documented a Calamovilfa longifolia - Stipa comata - Bouteloua gracilis community from CFB Suffield. This community was dominated by Stipa comata and Calamovilfa longifolia with approximately 3\% cover of Artemisia frigida. There was no mention of the presence of Selaginella densa. A number of other Stipa comata and Calamovilfa longifolia community types were mentioned in this report, but most include the presence of a distinct shrub layer. This community was noted to occur on sandy eolian or glaciofluvial materials with typically less than $5 \%$ slope. A Bouteloua gracilis Stipa comata - Calamovilfa longifolia community was noted from the Pakowki Sandhills region, where it occurs on well-drained sandy, subxeric sites (Komex 1993). It was noted to occur in the vicinity of dune areas and on highly stabilized dunes. Typical associated species included Koeleria macrantha, Agropyron smithii, Carex spp., Artemisia frigida, Heterotheca villosa, and Selaginella densa among others. A number of authors document a Koeleria macrantha - Artemisia frigida -Linum lewisii community that has been found in the Montane subregion (Corns and Achuff 1982; Achuff et al. 1986). This community is known to occur on dry, fluvial fans and aprons, morainal erosional scarps and eolian veneers. Sites were typically subxeric to xeric with exposed bare soil at the surface. Koeleria macrantha, Artemisia frigida, Linum lewisii, Antennaria nitida and Gaillardia aristata are considered to be characteristics species. 
Table 53. Similarity rating for Stipa comata - Artemisia frigida - Selaginella densa community types documented within Alberta.

\begin{tabular}{|l|c|l|}
\hline \multicolumn{1}{|c|}{$\begin{array}{c}\text { Similar Communities and } \\
\text { Citations }\end{array}$} & $\begin{array}{c}\text { Similarity } \\
\text { Rating }\end{array}$ & \multicolumn{1}{c|}{ Comments } \\
\hline $\begin{array}{l}\text { Calamovilfa longifolia - Artemisia frigida - } \\
\text { Koeleria macrantha - Festuca } \\
\text { saximontana / Selaginella densa } \\
\text { (Wheatley and Bentz 2002; Fehr 1984) }\end{array}$ & 2 & $\begin{array}{l}\text { While the site characteristics of this community described in the } \\
\text { literature matches the sites found in Wainwright during 2003, the } \\
\text { species composition is somewhat different. }\end{array}$ \\
\hline $\begin{array}{l}\text { Stipa comata - Koeleria macrantha - } \\
\text { Agropyron smithii (Meijer and Karpuk }\end{array}$ & 2 & $\begin{array}{l}\text { While the species composition of this community is somewhat similar to } \\
\text { that observed at Wainwright, the site characteristics are notably } \\
\text { different. }\end{array}$ \\
\hline $\begin{array}{l}\text { Artemisia frigida / Koeleria macrantha - } \\
\text { Carex obtusata (Meijer and Karpuk 1999) }\end{array}$ & 2 & $\begin{array}{l}\text { While some species found in this community type occur in the } \\
\text { community described from Wainwright, the general composition and } \\
\text { site characteristics are quite different. }\end{array}$ \\
\hline $\begin{array}{l}\text { Stipa comata - Koeleria macrantha - } \\
\text { Agropyron trachycaulum - Carex obtusata } \\
\text { (Meijer and Karpuk 1999) }\end{array}$ & 2 & $\begin{array}{l}\text { This community is somewhat similar in floristic composition, however } \\
\text { the parent materials and site characteristics are somewhat different. }\end{array}$ \\
\hline $\begin{array}{l}\text { Bouteloua gracilis - Stipa comata - } \\
\text { Calamovilfa longifolia (Komex 1993) }\end{array}$ & 2 & $\begin{array}{l}\text { While there is some similarity to the floristic composition and site } \\
\text { characteristics of this community, the dominant and co-dominant } \\
\text { species are notably different. }\end{array}$ \\
\hline $\begin{array}{l}\text { Calamovilfa longifolia - Stipa comata - } \\
\text { Bouteloua gracilis (Adams et al. 1997) }\end{array}$ & 2 & $\begin{array}{l}\text { This community is quite similar to that found in the Wainwright Dunes } \\
\text { area with very similar site characteristics. The floristic composition is } \\
\text { somewhat different, particularly the lack of Selaginella densa. }\end{array}$ \\
\hline $\begin{array}{l}\text { Koeleria macrantha - Artemisia frigida - } \\
\text { Linum lewisii (Corns and Achuff 1982; } \\
\text { Achuff et al. 1986) }\end{array}$ & 2 & $\begin{array}{l}\text { This community shares some floristic similarities and site characteristics } \\
\text { as the Wainwright community. }\end{array}$ \\
\hline
\end{tabular}

Numerous related community types have been recorded outside of Alberta and are listed in Table 54. Thorpe and Godwin (1993) documented an Artemisia frigida - Bouteloua gracilis - Carex eleocharis - Stipa comata - Koeleria cristata community from the Manito Sandhills in Saskatchewan. This community was characterized by grasslands on well-drained sandy loam to clay loam soils. Associated species included Rosa arkansana, Opuntia polycantha, Solidago missouriensis, Thermopsis rhombifolia, Anemone patens and Chrysopsis villosa at low percent covers. There is no mention of Selaginella densa being a prominent species. Hulett et al. (1966) documented a Stipa comata - Artemisia frigida community from the Dundurn Sandhills, in Saskatchewan. This community was noted to be a dominant type that occurred on stabilized dunes. Coupland $(1950 ; 1961)$ described a STIPA - BOUTELOUA faciation from the mixedgrass prairie region of Canada. This association was generally considered to be a climax association and it was noted that Selaginella densa was common, typically with at least $7 \%$ cover. Artemisia frigida was also noted to be common. Looman (1980) also noted a Stipa comata association found to be common (with Bouteloua gracilis) on dry prairie. The author noted that the cover of Bouteloua gracilis increased, gradually replacing Stipa comata as grazing increased. A variation of the community included Calamovilfa longifolia and occurred on sandy loam or loamy sand soils.

Hanson and Whitman (1938) described a Grama - Needlegrass - Sedge Type from North Dakota where it was found on upland plateaus to gentle upland slopes. Common species included Bouteloua gracilis, Stipa comata, Carex filifolia, C. stenophylla, Agropyron smithii and Koeleria cristata. NatureServe (2003) described a Hesperostipa comata - Bouteloua gracilis - Carex filifolia community type that is thought to be common throughout the northern and central Great Plains of the United States. This community typically occurred on flat to rolling topography with deep sandy loam to loam or coarsertextured soils. Moderate to moderately dense medium-tall grasses typically dominated the vegetation, with Stipa comata being the dominant species and Bouteloua gracilis and Carex filifolia as codominant species. 
Table 54. Similarity rating for Stipa comata - Artemisia frigida - Selaginella densa community type documented outside Alberta.

\begin{tabular}{|c|c|c|}
\hline Similar Communities and Citations & $\begin{array}{l}\text { Similarity } \\
\text { Rating }\end{array}$ & Comments \\
\hline $\begin{array}{l}\text { Artemisia frigida - Bouteloua gracilis - Carex } \\
\text { eleocharis - Stipa comata - Koeleria cristata } \\
\text { (Thorpe and Godwin 1993) }\end{array}$ & 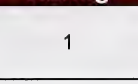 & $\begin{array}{l}\text { This community has a fairly similar species composition and } \\
\text { very similar site conditions. }\end{array}$ \\
\hline Stipa comata - Artemisia frigida (Hulett et al. 1966) & 2 & $\begin{array}{l}\text { The species composition varies somewhat, and site conditions } \\
\text { are somewhat different. }\end{array}$ \\
\hline $\begin{array}{l}\text { STIPA-BOUTELOUA Faciation (Coupland 1961; } \\
\text { Coupland 1950) }\end{array}$ & 1 & $\begin{array}{l}\text { This community has a similar floristic composition and similar } \\
\text { site conditions. }\end{array}$ \\
\hline Stipa comata ASSOCIATION (Looman 1980) & 2 & The species composition and site conditions area quite similar. \\
\hline $\begin{array}{l}\text { Grama - Needlegrass - Sedge Type (Hanson and } \\
\text { Whitman 1938) }\end{array}$ & 2 & $\begin{array}{l}\text { The species composition varies somewhat, and site conditions } \\
\text { are somewhat different. }\end{array}$ \\
\hline $\begin{array}{l}\text { Hesperostipa comata - Bouteloua gracilis - Carex } \\
\text { filifolia Herbaceous Vegetation (NatureServe 2003) }\end{array}$ & 2 & $\begin{array}{l}\text { This community is very similar floristically and in terms of site } \\
\text { conditions to that observed in Wainwright. }\end{array}$ \\
\hline $\begin{array}{l}\text { Hesperostipa comata - Bouteloua gracilis - Carex } \\
\text { filifolia (USGS 2002; MNHP 2002; Faber- } \\
\text { Langendoen 2001; Marriott and Faber-Langendoen } \\
\text { 2000; Schneider et al. 1997) }\end{array}$ & 2 & $\begin{array}{l}\text { This community shares many floristic similarities and matches } \\
\text { the site characteristics observed in Wainwright. }\end{array}$ \\
\hline $\begin{array}{l}\text { Calamovilfa longifolia - Hesperostipa comata } \\
\text { Herbaceous Vegetation (Faber-Langendoen 2001) }\end{array}$ & 3 & $\begin{array}{l}\text { This community shares some floristic similarities but has } \\
\text { different site characteristics than that observed in Wainwright. }\end{array}$ \\
\hline $\begin{array}{l}\text { Hesperostipa comata - Carex filifolia Herbaceous } \\
\text { Vegetation (NatureServe 2003) }\end{array}$ & $?(3)$ & $\begin{array}{l}\text { This community is described from Montana where it is given a } \\
\text { G4 conservation rating. Unfortunately no further information is } \\
\text { provided, making an assessment of similarity difficult. }\end{array}$ \\
\hline $\begin{array}{l}\text { Stipa comata / Carex filifolia (MNHP 2002; Hansen } \\
\text { and Hoffman 1988) }\end{array}$ & 2 & $\begin{array}{l}\text { This community type shares some floristic similarities and has } \\
\text { the same general habitat characteristics as that observed in } \\
\text { Wainwright. }\end{array}$ \\
\hline $\begin{array}{l}\text { Hesperostipa comata - Carex inops ssp. heliophila } \\
\text { Herbaceous Vegetation (NatureServe 2003; MNHP } \\
\text { 2002) }\end{array}$ & $?(3)$ & $\begin{array}{l}\text { This community is described from Montana and Wyoming } \\
\text { where it is given a G4 conservation rating. Unfortunately no } \\
\text { further information is provided, making an assessment of } \\
\text { similarity difficult. }\end{array}$ \\
\hline $\begin{array}{l}\text { Stipa comata / Carex heliophila (Schneider et al. } \\
\text { 1997; Hansen and Hoffman 1988) }\end{array}$ & 2 & $\begin{array}{l}\text { This community type shares many floristic similarities and has } \\
\text { the same general site characteristics as that observed in } \\
\text { Wainwright. }\end{array}$ \\
\hline
\end{tabular}

Calamovilfa longifolia was often a component on sandier soils, while Koeleria macrantha cover increased on degraded sites. Other common species included Artemisia frigida, Gutierrezia sarothrae and Rosa arkansana however their total cover typically did not exceed $5 \%$, except on overgrazed sites. Cover values for forbs were generally low, with the exception of Selaginella densa. Faber-Langendoen (2001) documented a Calamovilfa longifolia - Hesperostipa comata community type that was found in the central and northern Great Plains region, ranging from Colorado and Nebraska, north to Wyoming and South Dakota. The vegetation had an open canopy and was dominated by mid to tall grasses. Calamovilfa longifolia was the most prominent grass although Bouteloua gracilis, Koeleria macrantha, Achnatherum hymenoides, Sporobolus cryptandrus and Hesperostipa comata were also quite common. Sedges were reported to be uncommon but occasionally included Carex inops ssp. heliophila. Forb diversity ranged from low to moderate. Artemisia frigida, Artemisia ludoviciana, Gutierrezia sarothrae, Psoralidium tenuiflorum, and Yucca glauca were occasionally present. Shrubs occurred infrequently with low covers. This community was most frequently found on stabilized sand dunes, as well as in interdunal valleys or draws. Soils were generally medium to fine sands formed either from eolian or colluvial processes.

A number of sources described a Hesperostipa comata - Carex filifolia community generally from the Montana and South Dakota regions (NatureServe 2003; MNHP 2002; Hansen and Hoffman 1988). Hansen and Hoffman documented this community from the Custer National Forest in Montana and South Dakota, where it occurred on level or gently sloping sites with relatively little surface erosion. Stipa comata, Carex filifolia, Agropyron smithii, Bouteloua gracilis, Artemisia frigida and Koeleria macrantha consistently had the highest covers. Forb cover was notable, but was still exceeded by 
graminoid cover. The soil textures ranged from loams to loamy sand. A number of sources also described a Hesperostipa comata - Carex inops ssp. heliophila community (NatureServe 2003; MNHP 2002; Schneider et al. 1997; Hansen and Hoffman 1988). Hansen and Hoffman documented this community from the Custer National Forest in Montana and South Dakota where it occurred on relatively level uplands. Stipa comata and Carex heliophila were dominant, with Artemisia ludoviciana, Agropyron smithii, Koeleria macrantha, Stipa viridula, Antennaria rosea, Gaura coccinea, Aster ericoides, Artemisia frigida, Rosa arkansana and Petalostemon purpureum being common species. Selaginella densa was typically found in scattered dense mats, with about $16 \%$ cover on average. The soil textures ranged from loams to loamy sands.

\subsubsection{Preliminary Conservation Ranking of Stipa comata - Artemisia frigida - Selaginella densa Community}

Preliminary Rank: S3S4

This community type was found extensively in the Wainwright Dunes Ecological Reserve, occurring on generally level to gently sloping sand plains. Stipa comata dominated grassland communities, with associated species such as Artemisia frigida and Selaginella densa are quite extensive and common throughout the Great Plains regions, and the Grassland Natural Region of Alberta. However, this community is rather unique in the sense that many hectares have most likely been converted to agricultural use and also that it is so extensive as far north as it is.

NatureServe (2003) currently ranks a number of Stipa comata dominated communities as G4. However, due to the fact that central Alberta is reaching the northern limits of this community type's distribution, it should be ranked with a higher conservation ranking. As such a preliminary rank of S3S4 is suggested. 


\subsection{Conclusion}

The preliminary analysis of plot data and classification of the sand dune and sand plain plant communities in the Wainwright Dunes Ecological Reserve revealed 12 community types. Community types included all classes, except non-vascular dominated and sparsely vegetated. All proposed community types were described and assigned a suggested preliminary ranking. Cross-reference tables were created to present similar communities described in the literature, rate their similarity with the Wainwright Dunes Ecological Reserve communities and explain their relation to the proposed community types.

Several difficulties were encountered which should be noted. In the literature, community type descriptions vary from a single sentence to extremely detailed descriptions and in most instances, there is insufficient information to adequately describe community structure and assign a conservation rank (i.e. based on distribution and abundance). No quantification of area for community types could be found in the literature, aside from qualitative notes such as 'widely distributed' or 'abundant.' Furthermore, no quantification of the area of community types was required for this project or other similar projects in Alberta (e.g. Coenen and Bentz 2003). As such, determining the areal coverage of community types was done through observation and estimation. Mapping of community types at a relatively detailed scale would provide a greater confidence behind the estimation of conservation ranks for this project and provide a means to track impacts on community types in the future. Additional inventories of sandhill habitats within the subregion would also help greatly to clarify the distribution and quantity of plant community types.

The natural process of succession in sand dunes also poses difficulties in assessing plant communities. While the model for classifying plant communities (Grossman et al. 1998) follows an integrated physiognomic and floristic approach, plant community succession is largely overlooked. With respect to active eolian landscapes, changes in habitats and conditions can be observed in a relatively short time period. In several instances, community types noted in the published literature appeared to be somewhat similar to those observed in the Wainwright Dunes Ecological Reserve. However, the prominence of certain species (e.g. lichens, pioneer graminoids, etc.) tends to indicate different successional stages in a community although the habitat / site conditions appear to be virtually identical (e.g. active blowout). Consequently, it likely that several communities identified in the 2003 survey of the Wainwright Dunes Ecological Reserve are quite closely related to communities reported in current literature. However due to the limitations of the classification system these similarities may not be obvious, due to the different prominent species at slightly different successional stages.

The information in this report can be used to update the community-tracking list by including new community types. Finally, this report can also be used to decide which community types require further studies and to prioritize these studies. 


\subsection{Literature Cited}

Achuff, P.L. 1994. Natural Regions, Subregions and Natural History Themes of Alberta. Prepared for Parks Service, Alberta Environmental Protection, Edmonton, Alberta.

Achuff, P.L., I. Pengelly and C. White. 1986. Special Resources of Banff National Park. Banff National Park, Warden Service.

Adams, G.D., G.C.Trottier, W.L. Strong, I.D. MacDonald, S.J. Barry, P.G. Gregoire, G.W. Babish and G. Weiss. 1997. Vegetation Component Report: Canadian Forces Base Suffield National Wildlife Area Wildlife Inventory. Canadian Wildlife Service, Environment Canada, Prairie and Northern Region. Edmonton, Alberta.

Alberta Environmental Protection. 1993. Alberta plants and fungi - master species list and species group checklists. Pub. No.: Ref. 75. Edmonton, Alberta.

Alberta Sustainable Resource Development. 2003. Ecological land survey site description manual $-2^{\text {nd }}$ Edition. Edmonton, Alberta. 112pp.

Allen, L. 2003. Alberta Natural Heritage Information Centre Preliminary Plant Community Tracking List, Alberta Community Development, Edmonton, Alberta.

Barker, W.T. and W.C. Whitman. 1988. Vegetation of the Northern Great Plains. Rangelands 10(6) 266-272.

Bayrock, L.A. 1958. Glacial geology, Galahad - Hardisty District, Alberta. Research Council of Alberta, Report No, 57-3.

Beckingham, J.D. and J.H. Archibald. 1996. Field guide to ecosites of Northern Alberta. Natural Resources Canada, Canadian Forest Service, Northwest Region, Northern Forestry Centre, Edmonton, Alberta. Special Report 5.

Beckingham, J.D., I.G.W. Corns and J.H. Archibald. 1996. Field guide to ecosites of west-central Alberta. Natural Resources Canada, Canadian Forest Service, Northern Forestry Centre, Edmonton, Alberta. Special Report 9.

Bradley, L. and C. Bradley. 1977. Aspen Groveland Resource Assessment: Neutral Hills Area. Parks Planning and Design Branch, Alberta Recreation, Parks and Wildlife, Edmonton, $A B$.

Braun-Blanquet, J. 1965. Plant sociology: the study of plant communities. Authorized English translation of Pflanzensoziologie by J. Braun-Blanquet. Translated, rev. and ed. by George D. Fuller and Henry S. Conard.Hafner Publishing Co., Longon, England. 439 pp.

Burgess, R.L. 1965. A study of plant succession in the sandhills of southeastern North Dakota. Proceedings of the North Dakota Academy of Science 19:62-80.

Chadwick, H.W. and P.D. Dalke. 1965. Plant succession on dune sands in Fremont County, Idaho. Ecology 46(6): 765-780.

Coenen, V. and J. Bentz. 2003. Plant community classification of the Pakowki sandhills and sand plains. A report prepared for Resource Data Branch, Alberta Sustainable Resource Development.

Colorado Natural Heritage Program. 2003. Tracked natural plant communities. http://www.cnhp.colostate.edu/tracking/communities.html 
Cooper, S.V., C. Jean and B.L. Heidel. 1999. Plant associations and Related Botanical Inventory of the Beaverhead Mountains Section, Montana. Unpublished report to the Bureau of Land Management. Montana Natural Heritage Program, Helena. 235 pp.

Cooper, S.V., C. Jean and P. Hendricks. 2001. Biological Survey of a Prairie Landscape in Montana's Glaciated Plains. Report to the Bureau of Land Management, Montana Natural Heritage Program, Helena Montana. 24pp. plus appendices.

Corns, I.G.W. 1983. Forest community types of west-central Alberta in relation to selected environmental factors. Canadian Journal of Forest Research 13:995-1010.

Corns,I.G.W. and P.L. Achuff. 1982. Vegetation Type Descriptions in W.D. Holland and G.M. Coen (eds.). Ecological (Biophysical) Land Classification of Banff and Jasper National Parks. Alberta Institute of Pedology Pub. No. SS-82-44-1982.

Cottonwood Consultants Ltd. 1986. The Proposed Wainwright Ecological Reserve - A Biophysical Overview. Prepared for Alberta, Recreation and Parks, Edmonton, Alberta.

Coupland, R.T. 1950. Ecology of mixed prairie in Canada. Ecological Monographs 20:273-315.

Coupland, R.T. 1960. A reconsideration of grassland classification in the northern great plains of North America. Journal of Ecology 49:135-167.

David, P.P. 1977. Sand dune occurrences of Canada: a theme and resouce inventory stufy of aeolian landforms of Canada. Indian and Northern Affairs, National Parks Branch.

Dowding, E.S. 1929. The vegetation of Alberta: III The sandhill areas of central Alberta, with particular reference to the ecology of Arceuthobium americanum. Journal of Ecology, Vol. 17: 82-105.

Epp, H.T. and L. Townley-Smith. 1980. The great sand hills of Saskatchewan. Saskatchewan Deportment of the Environment, Policy, Planning and Research Branch. Regina, Saskatchewan.

Faber-Langendoen, D. editor. 2001. Plant communities of the Midwest: Classification in an ecological context. Association for Biodiversity Information, Arlington, VA. 61 pp. + appendix (705 pp.).

Fehr, A.W. 1982. The Candidate Rumsey Ecological Reserve: A Biophysical Inventory. Alberta Energy and Natural Resources. Public Lands Division, Edmonton, Alberta.

Fehr, A.W. 1984. Wainwright study area: A biophysical inventory. Natural Areas Program, Alberta Energy and Natural Resources. Natural Areas Technical Report No. 15. Edmonton, Alberta.

Griffiths, D.E. and G.C.D. Griffiths. 1987. Biophysical survey of Bilbey Natural Area. Alberta Forestry, Lands and Wildlife Information Centre, Edmonton, Alberta.

Grossman, D.H., K.L. Goodin and C.L. Reuss, editors. 1994. Rare plant communities of the conterminous United States: an initial survey. The Nature Conservancy, Arlington, Virginia, USA.

Grossman, D.H., D. Faber-Langendoen, A.S. Weakley, M. Anderson, P. Bourgeron, R. Crawford, K. Goodin, S. Laandal, K. Metzler, K.D. Patterson, M. Pyne, M. Reid and L. Sneddon. 1998. International classification of ecological communities: terrestrial vegetation of the United States, Volume 1. The National Vegetation Classification 
System: development, status and applications. The Nature Conservancy, Arlington, Virginia, USA.

Hansen, P.L. and G.R. Hoffman. 1988. The Vegetation of the Grand River / Cedar River, Sioux and Ashland Districts of the Custer National Forest: A Habitat Type Classification. General Technical Report RM-157.Rocky Mountain Forest and Range Experiment Station, Fort Collins, CO.

Hansen, P.L., R.D. Pfister, K. Boggs, B.J. Cook, J. Joy and D.K. Hinckley. 1995. Classification and management of Montana's riparian and wetland sites. Misc. Publication No.54 Montana Forest and Conservation Experiment Station, School of Forestry, University of Montana, Missoula, Montana.

Hanson, H.C. and W.C. Whitman. 1938. Grassland types in Western North Dakota. Ecological Monographs 8(1): 58-114.

Heidel, B, S.V. Cooper and C. Jean. 2000. Plant species of special concern and plant associations of Sheridan County, Montana. Report to U.S. Fish and Wildlife Service. Montana Natural Heritage Program, Helena, Montana. 22pp. plus appendices.

Hill, M.O. and H.G. Gauch. 1980. Detrended correspondence analysis: an improved ordination technique. Vegetatio 42:47-58.

Hulett, G.K., R.T. Coupland, R.L. Dix. 1966. The vegetation of dune sand areas within the grassland region of Saskatchewan. Canadian Journal of Botany 44: 1307-1331.

Jaques, D.R. 1977. The vegetation and effects of grazing on the eastern portion of the Suffield Military Reserve, Alberta. pp. D41-D190-. In Stelfox, J.G. ed. Effects of livestock grazing on mixed prairie range and wildlife in PFRA pastures. Suffield Military Reserve. Range-Wildlife Study Committee, Can. Wild. Ser. Rep. Edmonton, Alberta.

Kartesz, JT. 1999. A synonymized checklist and atlas with biological attributes for the vascular flora of the United States, Canada and Greenland. First edition. In: Kartesz, JT and CA Meacham. Synthesis of the North American flora [computer program]. Version 1.0. North Carolina Botanical Garden: Chapel Hill, NC.

Komex International Ltd. 1993. Preliminary report on biophysical inventory of the Pakowki Sandhills sensitive area. Land Information Services Division, Alberta Forestry Lands and Wildlife, Edmonton, Alberta.

Looman, J. 1980. The vegetation of the Canadian Prairie Provinces II. The grasslands, Part I. Phytocoenologia 8(2) 153-190.

Looman, J. 1983. T The vegetation of the Canadian Prairie Provinces IV - The woody vegetation, Part 1. Phytocoenologia 11(3) 297-330.

Macdonald, I.D. 1996. Vascular Plant Flora of Canadian Forces Base Suffield, National Wildlife Area. Canadian Wildlife Service, Environment Canada, Prairie and Northern Region, Edmonton, Alberta.

Marriott, H. J. and D. Faber-Langendoen. 2000. The Black Hills community inventory. Volume 2: Plant community descriptions. The Nature Conservancy, Midwest Conservation Science Center and Association for Biodiversity Information, Minneapolis, MN. 326 pp.

McClune, B. and M.J. Mefford. 1999. PC-ORD. Multivariate Analysis of Ecological Data, Version 4. MjM Software Design, Gleneden Beach, Oregon, USA. 
Meijer, M. and E. Karpuk. 1999. Dillberry Lake Provincial Park Biophysical Inventory. Natural Resources Service, Parkland Region, Alberta Environment, Edmonton, Alberta.

Montana Natural Heritage Program. 2002. 2002 List of Ecological Communities for Montana. Montana Natural Heritage Program, Montana State Library, Helena, Montana.

Moss, E.H. 1983. Flora of Alberta. $2^{\text {nd }}$ Edition Revised by J.G. Packer. University of Toronto Press, Toronto, Ontario.

NatureServe. 2003. NatureServe Explorer: An online encyclopedia of life [web application]. Version 1.8. NatureServe, Arlington, Virginia. Available http://www.NatureServe.org/explorer. (Accessed: November 1, 2003 ).

Patriquin, D.L. and D. L. Skinner. 1992. Review and assessment of the vegetation, wildlife and habitat of CFB Suffield, Alberta. D.A. Westworth and Associates, Edmonton, Alberta.

Pearson Timberline Forestry Consultants. 1993. Wainwright Dunes Ecological Reserve Vegetation Change / Disturbance Assessment. Prepared for Alberta Environmental Protection, Resource Information Division, Edmonton, Alberta.

Rust, S.K. 1997. Natural Plant Communities of Idaho: A Working List for the Conservation of Biological Diversity. Conservation Data Centre, Idaho Department of Fish and Game.

Schacht, W.H., J.D. Volesky, D. Bauer, A.J. Smart and E.M. Mousel. 2000. Plant community patterns on upland prairie in the eastern Nebraska sandhills. Prairie Naturalist 32(1):43-58. Jamestown, ND: Northern Prairie Wildlife Research Center Home Page. http://www.npwrc.usgs.ggov/resource/2001/plantcom/plantcom.htm (Version 20AUG2001).

Schneider, R.E., D. Faber-Langendoen, R.C. Crawford and A.D. Weakley. 1997. The Status of Biodiversity in the Great Plains: Great Plains Vegetation Classification. Supplemental Document 1 in: W.R. Ostlie, R.E. Schneider, J.M. Aldrich, T.M. Faust, R.L.B. McKim and S.J. Chaplin. The Status of Biodiversity on the Great Plains. The Nature Conservancy, Arlington, Virginia. 75pp. $+X$.

Strong, W.L. and K.R. Leggat. 1992. Ecoregions of Alberta. Prepared for Alberta Forestry, L.ands and Wildlife. Land Information Services Division. Edmonton, Alberta.

Strong, W.L. 2002. Lodgepole pine / Labrador tea community types of western Canada. Canadian Journal of Botany 80:151-165.

Thompson and Hansen 2002. Classification and management of riparian and wetland sites of the Alberta Grassland Natural Region and adjacent subregions. Bitterroot Restoration Inc. Prepared for the Alberta Riparian Habitat Management Program - Cows and Fish, Lethbridge, Alberta. 416 pp.

Thorpe, J. and R. Godwin. 1993. Vegetation Survey of the Manito San Hills. Applied Plant Ecology Section, Saskatchewan Research Council. SRC Publication No. E-25501-E-93.

United States Geological Survey. 2002. Agate Fossil Beds National Monument USGSNPS Vegetation Mapping Program Products-Vegetation Description. http:/biology/usgs.gov/npsveg/agfo/index.html

Wallis, C.W. 1980. Montane, Foothills, Parkland and Southwest Rivers Natural Landscapes Survey 1978-1979. Alberta Recreation and Parks, Edmonton, Alberta. 
Wallis, C. and C. Wershler. 1988. Rare Wildlife and Plant Conservation Studies in Sandhill and Sand Plain Habitats of Southern Alberta. Alberta Forestry, Lands and Wildlife, Alberta Recreation and Parks. Edmonton, Alberta.

Wanek, W.J. and R.L. Burgess. 1965. Floristic composition of the sand prairies of southeastern North Dakota. Proceedings of the North Dakota Academy of Science 19:26-40.

Wheatley, M. and J. Bentz. 2002. A preliminary classification of plant communities in the Central Parkland Natural Subregion of Alberta. Alberta Sustainable Resource Development, Public Lands Division, Resource Data Branch, Edmonton, Alberta.

Whittaker, R.H. 1978. Ordination of Plant Communities. Dr. W. Junk Publishers, The Hague, Boston.

Wroe, R.A. 1971. Synecology of a Festuca scabrella Torr. Grassland. Masters Thesis, Department of Plant Science, University of Alberta, Edmonton, Alberta. 


Appendix 1. Glossary of Scientific and Common Plant Species Names 



\begin{tabular}{|c|c|}
\hline Latin Name & Common Name \\
\hline Agoseris glauca & false dandelion \\
\hline Agropyron dasystachyum & northern wheatgrass \\
\hline Agrostis scabra & rough hair grass \\
\hline Amelanchier alnifolia & saskatoon \\
\hline Anemone multifida & cut-leaf anemone \\
\hline Anemone patens & prairie crocus \\
\hline Antennaria parvifolia & small-leaved everlasting \\
\hline Arabis holboellii & reflexed rock cress \\
\hline Aralia nudicaulis & wild sarsaparilla \\
\hline Arctostaphylos uva-ursi & common bearberry \\
\hline Artemisia campestris & plains wormwood \\
\hline Artemisia frigida & pasture sagewort \\
\hline Artemisia ludoviciana & prairie sagewort \\
\hline Aster ciliolatus & Lindley's aster \\
\hline Betula occidentalis & water birch \\
\hline Betula papyrifera & white birch \\
\hline Bouteloua gracilis & blue grama \\
\hline Bromus inermis & awnless brome \\
\hline Calamagrostis canadensis & bluejoint \\
\hline Calamovilfa longifolia & sand grass \\
\hline Carex filifolia & thread-leaved sedge \\
\hline Carex pensylvanica ssp. heliophila & sun-loving sedge \\
\hline Carex siccata & hay sedge \\
\hline Carex spp. & sedge \\
\hline Chamaerhodos erecta & chamaerhodos \\
\hline Chenopodium album & lamb's quarters \\
\hline Chenopodium leptophyllum & narrow-leaved goosefoot \\
\hline Chenopodium pratericola & goosefoot \\
\hline Cladina mitis & reindeer lichen \\
\hline Cladonia uncialis & lichen \\
\hline Comandra umbellata & bastard toadflax \\
\hline Cornus canadensis & bunchberry \\
\hline Cornus stolonifera & red-osier dogwood \\
\hline Corylus cornuta & beaked hazelnut \\
\hline Descurainia sophia & flixweed \\
\hline Disporum trachycarpum & fairy bells \\
\hline Elaeagnus commutata & silverberry \\
\hline Elymus candensis & Canada wild rye \\
\hline Epilobium angustifolium & common fireweed \\
\hline Equisetum hymenale & common scouring rush \\
\hline Erigeron glabellus & smooth fleabane \\
\hline Erysimum asperum & prairie rocket \\
\hline Festuca hallii & plains rough fescue \\
\hline Festuca saximontana & Rocky Mountain fescue \\
\hline Fragaria virginiana & wild strawberry \\
\hline Gaillardia aristata & gaillardia \\
\hline
\end{tabular}




\begin{tabular}{|c|c|}
\hline Latin Name & Common Name \\
\hline Gallium boreale & northern bedstraw \\
\hline Gallium triflorum & sweet-scented bedstraw \\
\hline Gaura coccinea & scarlet butterflyweed \\
\hline Geum triflorum & three-flowered avens \\
\hline Hackelia americana & nodding stickseed \\
\hline Helianthus annuus & common annual sunflower \\
\hline Heliotrichon hookeri & Hooker's oat grass \\
\hline Heterotheca villosa & golden aster \\
\hline Heuchera richardsonii & Richardson's alumroot \\
\hline Juncus balticus & wire rush \\
\hline Juniperus communis & ground juniper \\
\hline Juniperus horizontalis & creeping juniper \\
\hline Kochia scoparia & summer cypress \\
\hline Koeleria macrantha & June grass \\
\hline Lathyrus ochroleucus & cream-coloured vetchling \\
\hline Lepidium densiflorum & common pepper-grass \\
\hline Linnea borealis & twinflower \\
\hline Lonicera dioica & twining honeysuckle \\
\hline Maianthemum candense & wild lily-of-the-valley \\
\hline Opuntia fragilis & brittle prickly-pear \\
\hline Oryzopsis asperifolia & white-grained mountain rice grass \\
\hline Poa interior & inland bluegrass \\
\hline Poa palustris & fowl bluegrass \\
\hline Poa pratensis & Kentucky bluegrass \\
\hline Populus balsamifera & balsam poplar \\
\hline Populus tremuloides & aspen \\
\hline Potentilla hippiana & wooly cinquefoil \\
\hline Prunus virginiana & choke cherry \\
\hline Pyrola asarifolia & common pink wintergreen \\
\hline Rhus radicans & poison ivy \\
\hline Ribes oxyacanthoides & northern gooseberry \\
\hline Ribes triste & wild red currant \\
\hline Rosa acicularis & prickly rose \\
\hline Rosa arkansana & prairie rose \\
\hline Rubus idaeus & wild red raspberry \\
\hline Rubus pubescens & dewberry \\
\hline Salix bebbiana & beaked willow \\
\hline Salix petiolaris & basket willow \\
\hline Sanicula marilandica & snakeroot \\
\hline Schizachne purpurescens & purple oat grass \\
\hline Scutellaria galericulata & marsh scullcap \\
\hline Selaginella densa & prairie selaginella \\
\hline Shepherdia candensis & Canada buffalo berry \\
\hline Silene drummondii & Drummond's cockle \\
\hline Smilacina stellata & star-flowered Solomon's-seal \\
\hline Solidago candensis & Canada goldenrod \\
\hline
\end{tabular}




\begin{tabular}{|l|l|}
\hline \multicolumn{1}{|c|}{ Latin Name } & \multicolumn{1}{c|}{ Common Name } \\
\hline Solidago missouriensis & low goldenrod \\
\hline Solidago spathulata & mountain goldenrod \\
\hline Spirea alba & narrow-leaved meadowsweet \\
\hline Sporobolus cryptandrus & sand dropseed \\
\hline Stipa comata & needle and thread \\
\hline Stipa spartea & porcupine grass \\
\hline Symphoricarpos albus & snowberry \\
\hline Symphoricarpos occidentalis & buckbrush \\
\hline Thalictrum venulosum & veiny meadow rue \\
\hline Thermopsis rhombifolia & golden bean \\
\hline Viburnum opulus & high-bush cranberry \\
\hline Viola adunca & early blue violet \\
\hline Viola canadensis & western Canada violet \\
\hline
\end{tabular}




\begin{tabular}{|c|c|}
\hline Common Name & Latin Name \\
\hline aspen & Populus tremuloides \\
\hline awnless brome & Bromus inermis \\
\hline balsam poplar & Populus balsamifera \\
\hline basket willow & Salix petiolaris \\
\hline bastard toadflax & Comandra umbellata \\
\hline beaked hazelnut & Corylus cornuta \\
\hline beaked willow & Salix bebbiana \\
\hline blue grama & Bouteloua gracilis \\
\hline bluejoint & Calamagrostis canadensis \\
\hline brittle prickly-pear & Opuntia fragilis \\
\hline buckbrush & Symphoricarpos occidentalis \\
\hline bunchberry & Cornus canadensis \\
\hline Canada buffalo berry & Shepherdia candensis \\
\hline Canada goldenrod & Solidago candensis \\
\hline Canada wild rye & Elymus candensis \\
\hline chamaerhodos & Chamaerhodos erecta \\
\hline choke cherry & Prunus virginiana \\
\hline common annual sunflower & Helianthus annuus \\
\hline common bearberry & Arctostaphylos uva-ursi \\
\hline common fireweed & Epilobium angustifolium \\
\hline common pepper-grass & Lepidium densiflorum \\
\hline common pink wintergreen & Pyrola asarifolia \\
\hline common scouring rush & Equisetum hymenale \\
\hline cream-coloured vetchling & Lathyrus ochroleucus \\
\hline creeping juniper & Juniperus horizontalis \\
\hline cut-leaf anemone & Anemone multifida \\
\hline dewberry & Rubus pubescens \\
\hline Drummond's cockle & Silene drummondii \\
\hline early blue violet & Viola adunca \\
\hline fairy bells & Disporum trachycarpum \\
\hline false dandelion & Agoseris glauca \\
\hline flixweed & Descurainia sophia \\
\hline fowl bluegrass & Poa palustris \\
\hline gaillardia & Gaillardia aristata \\
\hline golden aster & Heterotheca villosa \\
\hline golden bean & Thermopsis rhombifolia \\
\hline goosefoot & Chenopodium pratericola \\
\hline ground juniper & Juniperus communis \\
\hline hay sedge & Carex siccata \\
\hline high-bush cranberry & Viburnum opulus \\
\hline Hooker's oat grass & Heliotrichon hookeri \\
\hline inland bluegrass & Poa interior \\
\hline June grass & Koeleria macrantha \\
\hline Kentucky bluegrass & Poa pratensis \\
\hline lamb's quarters & Chenopodium album \\
\hline lichen & Cladonia uncialis \\
\hline
\end{tabular}




\begin{tabular}{|c|c|}
\hline Common Name & Latin Name \\
\hline Lindley's aster & Aster ciliolatus \\
\hline low goldenrod & Solidago missouriensis \\
\hline marsh scullcap & Scutellaria galericulata \\
\hline mountain goldenrod & Solidago spathulata \\
\hline narrow-leaved goosefoot & Chenopodium leptophyllum \\
\hline narrow-leaved meadowsweet & Spirea alba \\
\hline needle and thread & Stipa comata \\
\hline nodding stickseed & Hackelia americana \\
\hline northern bedstraw & Gallium boreale \\
\hline northern gooseberry & Ribes oxyacanthoides \\
\hline northern wheatgrass & Agropyron dasystachyum \\
\hline pasture sagewort & Artemisia frigida \\
\hline plains rough fescue & Festuca hallii \\
\hline plains wormwood & Artemisia campestris \\
\hline poison ivy & Rhus radicans \\
\hline porcupine grass & Stipa spartea \\
\hline prairie crocus & Anemone patens \\
\hline prairie rocket & Erysimum asperum \\
\hline prairie rose & Rosa arkansana \\
\hline prairie sagewort & Artemisia ludoviciana \\
\hline prairie selaginella & Selaginella densa \\
\hline prickly rose & Rosa acicularis \\
\hline purple oat grass & Schizachne purpurescens \\
\hline red-osier dogwood & Cornus stolonifera \\
\hline reflexed rock cress & Arabis holboellii \\
\hline reindeer lichen & Cladina mitis \\
\hline Richardson's alumroot & Heuchera richardsonii \\
\hline Rocky Mountain fescue & Festuca saximontana \\
\hline rough hair grass & Agrostis scabra \\
\hline sand dropseed & Sporobolus cryptandrus \\
\hline sand grass & Calamovilfa longifolia \\
\hline saskatoon & Amelanchier alnifolia \\
\hline scarlet butterflyweed & Gaura coccinea \\
\hline sedge & Carex spp. \\
\hline silverberry & Elaeagnus commutata \\
\hline small-leaved everlasting & Antennaria parvifolia \\
\hline smooth fleabane & Erigeron glabellus \\
\hline snakeroot & Sanicula marilandica \\
\hline snowberry & Symphoricarpos albus \\
\hline star-flowered Solomon's-seal & Smilacina stellata \\
\hline summer cypress & Kochia scoparia \\
\hline sun-loving sedge & Carex pensylvanica ssp. heliophila \\
\hline sweet-scented bedstraw & Gallium triflorum \\
\hline thread-leaved sedge & Carex filifolia \\
\hline three-flowered avens & Geum triflorum \\
\hline twinflower & Linnea borealis \\
\hline
\end{tabular}




\begin{tabular}{|l|l|}
\hline \multicolumn{1}{|c|}{ Common Name } & \multicolumn{1}{c|}{ Latin Name } \\
\hline twining honeysuckle & Lonicera dioica \\
\hline veiny meadow rue & Thalictrum venulosum \\
\hline water birch & Betula occidentalis \\
\hline western Canada violet & Viola canadensis \\
\hline white birch & Betula papyrifera \\
\hline white-grained mountain rice grass & Oryzopsis asperifolia \\
\hline wild lily-of-the-valley & Maianthemum candense \\
\hline wild red currant & Rives triste \\
\hline wild red raspberry & Rubus idaeus \\
\hline wild sarsaparilla & Aralia nudicaulis \\
\hline wild strawberry & Fragaria virginiana \\
\hline wire rush & Juncus balticus \\
\hline wooly cinquefoil & Potentilla hippiana \\
\hline
\end{tabular}




Appendix 2. PC-ORD Output from Detrended Correspondence Analysis of Plot Data 

$\star \star \star \star \star \star * \star \star \star * \star \star \star * \star * \star * \star *$
PC-ORD, Version 4.27
30 Oct $2003,10: 25$

Test

Number of non-zero data items: 810

Downweighting selected. Weights applied to columns, in sequential order:

$\begin{array}{lllllllllll}0.878 & 0.523 & 1.000 & 0.908 & 0.785 & 0.675 & 0.288 & 0.935 & 0.558 & 1.000\end{array}$

$\begin{array}{lllllllllllll}0.476 & 1.000 & 1.000 & 1.000 & 0.771 & 0.509 & 1.000 & 0.761 & 0.780 & 1.000\end{array}$

$\begin{array}{llllllllllll}1.000 & 1.000 & 1.000 & 0.471 & 1.000 & 0.884 & 0.621 & 1.000 & 1.000 & 1.000\end{array}$

$\begin{array}{llllllllllll}0.918 & 0.385 & 0.821 & 0.485 & 1.000 & 0.621 & 0.709 & 0.684 & 0.761 & 1.000\end{array}$

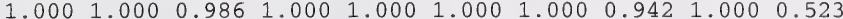

$\begin{array}{lllllllllll}0.471 & 0.540 & 0.442 & 1.000 & 1.000 & 0.567 & 0.698 & 1.000 & 0.471 & 1.000\end{array}$

$\begin{array}{lllllllllll}1.000 & 1.000 & 0.471 & 0.828 & 0.471 & 0.471 & 1.000 & 0.698 & 0.575 & 1.000\end{array}$

$\begin{array}{lllllllllllll}0.527 & 1.000 & 0.905 & 1.000 & 0.727 & 0.776 & 0.419 & 1.000 & 1.000 & 0.357\end{array}$

$\begin{array}{llllllllllll}0.998 & 1.000 & 0.780 & 0.362 & 1.000 & 0.471 & 1.000 & 0.283 & 0.523 & 1.000\end{array}$

$\begin{array}{lllllllllll}0.471 & 1.000 & 1.000 & 1.000 & 1.000 & 1.000 & 1.000 & 0.883 & 1.000 & 0.620\end{array}$

$\begin{array}{lllll}1.000 & 0.362 & 0.303 & 1.000 & 1.000\end{array}$

Axes are rescaled

Number of segments: 30

Threshold: 0.00

Total variance ("inertia") in the species data:

$0.2084986269=$ residual at iteration

0.0484788418 = residual at iteration

$0.0028454519=$ residual at iteration

$0.0002573977=$ residual at iteration

$0.0000184850=$ residual at iteration

$0.0000018544=$ residual at iteration

$0.0000001855=$ residual at iteration

$0.2000803500=$ residual at iteration

$0.1048777625=$ residual at iteration

$0.0104386704=$ residual at iteration

0.0008750346 = residual at iteration

$0.0000822394=$ residual at iteration

$0.0000069755=$ residual at iteration

0.0000006538 = residual at iteration

0.0000000994 = residual at iteration

0.8859433532 = eigenvalue

Length of gradient:

Length of segments:

Length of segments:

Length of segments:

Length of gradient:

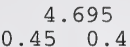

$0.45 \quad 0.43$

$\begin{array}{lll}0.49 & 0.43 & 0.40\end{array}$

$0.09 \quad 0.10$

0.20

6.352

Length of gradient:

Length of segments:

Length of segments:

Length of segments:

Length of segments:

Length of gradient:

\begin{tabular}{ll}
\multicolumn{2}{c}{7.305} \\
0.23 & 0.23 \\
0.19 & 0.19 \\
0.19 & 0.18 \\
0.16 & 0.16
\end{tabular}

0.23

0.19

$0.16 \quad 0.18 \quad 0.19$

$$
7.360
$$

$$
\text { -....... Axis } 2
$$

$0.1812712550=$ residual at iteration

0.0220914651 = residual at iteration

$0.0034740719=$ residual at iteration

$0.0004910100=$ residual at iteration

0.0000816786 = residual at iteration

0.0000119713 = residual at iteration

$0.0000020107=$ residual at iteration

$0.0000002945=$ residual at iteration

0.0000000631 = residual at iteration

0.4167989194 = eigenvalue

Length of gradient:

Length of segments:

Length of segments:

Length of gradient:

$\begin{array}{ll}2.669 \\ 0.25 & 0.26 \\ 0.11 & 0.10\end{array}$

0.28

3. 449

Length of gradient:

Length of segments:

Length of segments:

Length of gradient:

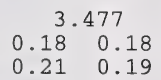

$\begin{array}{lll}0.18 & 0.18 & 0.17 \\ 0.21 & 0.19 & 0.18\end{array}$ 3. 459

0.29

0.29

0.27

0.22

0.16

0.13

0.11

- Axis 3

0.0595666654 = residual at iteration

0.0442739502 = residual at iteration

0.0037337963 = residual at iteration
0.18

0.17

0.18

0.20

0.22

0.25

0.25

0.23 


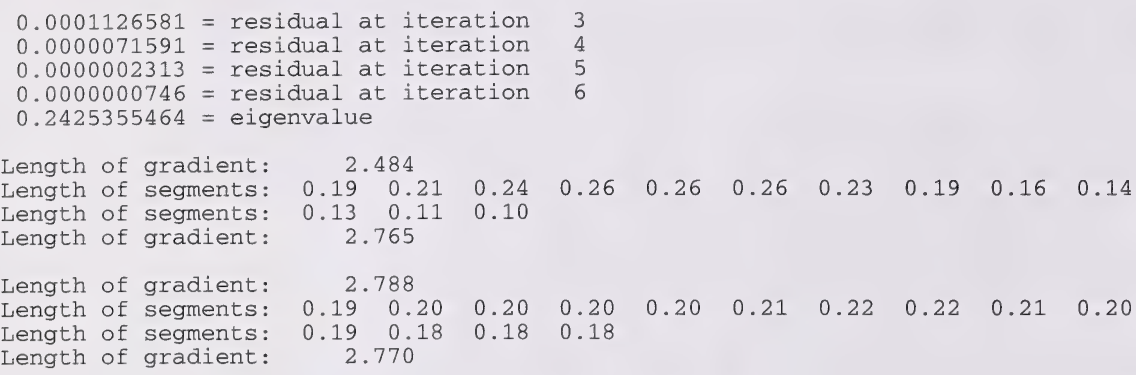

Test

SPECIES SCORES

$\mathrm{N}$ NAME

1 AGOSGLA6

2 AGRODAS7

3 AGROSCA7

4 AMELALN

5 ANEMMUL6

6 ANEMPAT6

7 ANTEPAR6

8 ARABHOL6

9 ARALNUD6

10 ARCTUVA5

11 ARTECAM6

12 ARTEFRI6

13 ARTELUD6

14 ASTECIL6

15 BETUOCC

16 BETUPAP

17 BOUTGRA7

18 BROMINE7

19 CALACAN7

20 CALALON7

21 CAREFIL7

22 CAREPEN7

23 CARESIC7

24 CAREX7

25 CETRUNC9

26 CHAMERE6

27 CHENALB6

28 CHENLEP6

29 CHENPRA6

30 CLADMIT9

31 COMAUMB6

32 CORNCAN6

33 CORNSTO

34 CORYCOR

35 DESCSOP6

36 DISPTRA6

37 ELAECOM

38 ELYMCAN7

39 EPILANG6

40 EQUIHYE6

41 ERIGGLA6

42 ERYSASP6

43 FESTHAL 7

44 FESTSAX7

45 FRAGVIR6

46 GAILARI6

47 GALIBOR6

48 GALITRI 6

49 GAURCOC6

50 GEUMTRIG

51 HACKAME6

52 HELIANN6

53 HELIHOO 7

54 HETEVIL6

55 HEUCRIC 6

56 JUNCBAL7

57 JUNICOM5

58 JUNIHOR 5

$59 \mathrm{KOCHSCO} 6$

60 KOELMAC 7

$\begin{array}{rrr}\text { AX1 } & \text { AX2 } & \text { AX3 } \\ 36 & -33 & 284 \\ 92 & 5 & 393 \\ 196 & 35 & 4 \\ 399 & 75 & -20 \\ 133 & 46 & 100 \\ -49 & -114 & 229 \\ -29 & -71 & 238 \\ 55 & 57 & 80 \\ 505 & 148 & 228 \\ 153 & 285 & 160 \\ 23 & 23 & 281 \\ -30 & -55 & 171 \\ 41 & 17 & 222 \\ 420 & 113 & 192 \\ 277 & 306 & 325 \\ 757 & 134 & 128 \\ 2 & -59 & 241 \\ 632 & 116 & 33 \\ 754 & 135 & 136 \\ 1 & 315 & 35 \\ -9 & 133 & 226 \\ 89 & 285 & 180 \\ 181 & 232 & 39 \\ 596 & 298 & 336 \\ 63 & 225 & 200 \\ -10 & 225 & -4 \\ 143 & 44 & 71 \\ 97 & 318 & 89 \\ 55 & 212 & 89 \\ 76 & 92 & 254 \\ 181 & 30 & 358 \\ 725 & 135 & 137 \\ 594 & 136 & 112 \\ 519 & 148 & 191 \\ 149 & 64 & 87 \\ 438 & 84 & 124 \\ 162 & 2 & -209 \\ 237 & 305 & 54 \\ 616 & 286 & 317 \\ 127 & 121 & -35 \\ 248 & 80 & 297 \\ 0 & 89 & 86 \\ 169 & 197 & 20 \\ 187 & 177 & 289 \\ 644 & 237 & 248 \\ -3 & -41 & 290 \\ 358 & 76 & 20 \\ 710 & 142 & 193 \\ -9 & 53 & -36 \\ -57 & -137 & 216 \\ 23 & -14 & -66 \\ -56 & 404 & -16 \\ 3 & 41 & 264 \\ 25 & 64 & 57 \\ 227 & 46 & 295 \\ 157 & 51 & 433 \\ 253 & 232 & 200 \\ 151 & 207 & 133 \\ 5 & 297 & 21 \\ 73 & 51 & 219 \\ & & \end{array}$

RANKED 1 $E I G=0.886$

16 BETUPAP

19 CALACAN7 754

86 SCUTGAL6 752

83 SALIPET 751

32 CORNCAN6 725

48 GALITRI6

77 RIBETRI 709

80 RUBUIDA 700

81 RUBUPUB6 671

75 PYROASA6 656

45 FRAGVIR6 644

76 RIBEOXY 638

18 BROMINE7 632

39 EPILANG6 616

24 CAREX7

33 CORNSTO

69 POAPAL7

103 VIBUOPU4

105 VIOLCAN6

34 CORYCOR

71 POPUBAL

9 ARALNUD6

63 LINNBOR 5

84 SANIMAR6

64 LONIDIO

88 SHEPCAN

100 THALVEN6

104 VIOLADU6

78 ROSAACI

36 DISPTRA6

99 SYMPOCC

14 ASTECIL6

65 MAIACAN7

61 LATHOCH6

90 SMILSTE6

4 AMELALN

70 POAPRA7

85 SCHIPUR7

47 GALIBOR6

98 SYMPALB

102 RHUSRYD5

67 ORYZASP7

91 SOLICAN6

72 POPUTRE

82 SALIBEB

94 SPIRALB

15 BETUOCC

57 JUNICOM5

74 PRUNVIR

41 ERIGGLA6

38 ELYMCAN7

55 HEUCRIC 6

3 AGROSCA7

101 THERRHO6

44 FESTSAX7

23 CARESIC7

31 COMAUMB

43 FESTHAL 7

37 ELAECOM

92 SOLIMIS 6
RANKED 2

$\mathrm{EIG}=0.417$

52 HELIANN6 404

95 SPORCRY7 402

28 CHENLEP6 318

20 CALALON7 315

15 BETUOCC 306

38 ELYMCAN7 305

24 CAREX7 298

59 KOCHSCO6 297

91 SOLICAN6 288

39 EPILANG6 286

10 ARCTUVA $5-285$

22 CAREPEN7 285

67 ORYZASP7 252

85 SCHIPUR7 244

45 FRAGVIR6 237

23 CARESIC7 232

57 JUNICOM5 232

25 CETRUNC9 225

26 CHAMERE6 225

29 CHENPRA 612

58 JUNIHOR5 207

43 FESTHAL7 197

70 POAPRA7 182

76 RIBEOXY 180

104 VIOLADU6 179

44 FESTSAX7 177

88 SHEPCAN 176

69 POAPAL7 174

89 SILEDRU6 171

84 SANIMAR6 170

63 LINNBOR5 163

71 POPUBAL 153

34 CORYCOR 148

9 ARALNUD6 148

94 SPIRALB 145

61 LATHOCH6 145

75 PYROASA 6143

77 RIBETRI 143

48 GALITRI6 142

81 RUBUPUB6 141

86 SCUTGAL6 138

103 VIBUOPU4 138

33 CORNSTO 136

83 SALIPET 136

32 CORNCAN6 135

19 CALACAN7 135

80 RUBUIDA 135

16 BETUPAP 134

21 CAREFIL7 133

100 THALVEN6 129

64 LONIDIO 127

40 EQUIHYE6 121

18 BROMINE7 116

72 POPUTRE 115

14 ASTECIL6 113

78 ROSAACI 104

93 SOLISPA6 100

105 VIOLCAN6 99

30 CLADMIT9 92

42 ERYSASP6 89 


$\begin{array}{rlrrr}61 & \text { LATHOCH6 } & 404 & 145 & 23 \\ 62 & \text { LEPIDEN6 } & 112 & -41 & 6 \\ 63 & \text { LINNBOR5 } & 502 & 163 & 257 \\ 64 & \text { LONIDIO } & 490 & 127 & 68 \\ 65 & \text { MAIACAN7 } & 411 & 88 & -35 \\ 66 & \text { OPUNFRA6 } & 6 & 62 & 265 \\ 67 & \text { ORYZASP7 } & 351 & 252 & 235 \\ 68 & \text { POAINT7 } & 96 & 63 & 125 \\ 69 & \text { POAPAL7 } & 582 & 174 & 137 \\ 70 & \text { POAPRA7 } & 394 & 182 & 248 \\ 71 & \text { POPUBAL } & 512 & 153 & 221 \\ 72 & \text { POPUTRE } & 319 & 115 & 37 \\ 73 & \text { POTEHIP6 } & -28 & -108 & 268 \\ 74 & \text { PRUNVIR } & 250 & 44 & -68 \\ 75 & \text { PYROASA6 } & 656 & 143 & 177 \\ 76 & \text { RIBEOXY } & 638 & 180 & 260 \\ 77 & \text { RIBETRI } & 709 & 143 & 207 \\ 78 & \text { ROSAACI } & 455 & 104 & 42 \\ 79 & \text { ROSAARK5 } & 42 & 0 & 52 \\ 80 & \text { RUBUIDA } & 700 & 135 & 151 \\ 81 \text { RUBUPUB6 } & 671 & 141 & 159 \\ 82 & \text { SALIBEB } & 314 & 82 & 371 \\ 83 & \text { SALIPET } & 751 & 136 & 137 \\ 84 & \text { SANIMAR6 } & 494 & 170 & 274 \\ 85 & \text { SCHIPUR7 } & 392 & 244 & 262 \\ 86 & \text { SCUTGAL6 } & 752 & 138 & 145 \\ 87 & \text { SELADEN6 } & 22 & -3 & 160 \\ 88 & \text { SHEPCAN } & 488 & 176 & 285 \\ 89 & \text { SILEDRU6 } & 49 & 171 & -49 \\ 90 & \text { SMILSTE6 } & 403 & 83 & 34 \\ 91 & \text { SOLICAN6 } & 349 & 288 & 316 \\ 92 & \text { SOLIMIS6 } & 162 & 61 & 194 \\ 93 & \text { SOLISPA6 } & 124 & 100 & 294 \\ 94 & \text { SPIRALB } & 277 & 145 & 268 \\ 95 & \text { SPORCRY7 } & -69 & 402 & -5 \\ 96 & \text { STIPCOM7 } & -24 & -6 & 176 \\ 97 & \text { STIPSPA7 } & 48 & -60 & 248 \\ 98 & \text { SYMPALB } & 358 & 66 & -46 \\ 99 & \text { SYMPOCC } & 430 & 71 & 27 \\ 100 & \text { THALVEN6 } & 465 & 129 & 140 \\ 101 & \text { THERRHO6 } & 190 & 67 & 108 \\ 102 & \text { RHUSRYD5 } & 357 & 72 & 24 \\ 103 & \text { VIBUOPU4 } & 537 & 138 & 82 \\ 104 & \text { VIOLADU6 } & 459 & 179 & 120 \\ 105 & \text { VIOLCAN6 } & 523 & 99 & 24 \\ & & & & \end{array}$

56 JUNCBAL7

10 ARCTUVA5

58 JUNIHOR5

35 DESCSOP6

27 CHENALB6

5 ANEMMUL 6

40 EQUIHYE6

93 SOLISPA6

62 LEPIDEN6

28 CHENLEP 6

68 POAINT7

2 AGRODAS7

22 CAREPEN7

30 CLADMIT9

60 KOELMAC 7

25 CETRUNC 9

8 ARABHOL 6

29 CHENPRA6

89 SILEDRU6

97 STIPSPA7

79 ROSAARK5

13 ARTELUD6

1 AGOSGLA6

54 HETEVIL6

51 HACKAME6

11 ARTECAM6

87 SELADEN6

66 OPUNFRA6

59 KOCHSCO6

53 HELIHOO

17 BOUTGRA7

20 CALALON7

42 ERYSASP6

46 GAILARI 6

21 CAREFIL 7

49 GAURCOC6

26 CHAMERE6

96 STIPCOM7

73 POTEHIP6

7 ANTEPAR6

12 ARTEFRI6

6 ANEMPAT6

52 HELIANN6

50 GEUMTRI 6

95 SPORCRY7

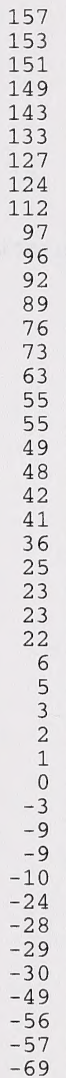

65 MAIACAN7

36 DISPTRA6

90 SMILSTE6

82 SALIBEB

41 ERIGGLA6

47 GALIBOR6

4 AMELALN

102 RHUSRYD5

99 SYMPOCC

101 THERRHO 6

98 SYMPALB

35 DESCSOP6

54 HETEVIL6

68 POAINT7

66 OPUNFRA6

92 SOLIMIS6

8 ARABHOL 6

49 GAURCOC6

60 KOELMAC7

56 JUNCBAL 7

5 ANEMMUL6 6

55 HEUCRIC6

74 PRUNVIR

27 CHENALB6

53 HELIHOO

3 AGROSCA7

31 COMAUMB6

11 ARTECAM6

13 ARTELUD6

2 AGRODAS7

37 ELAECOM

79 ROSAARK5

87 SELADEN6

96 STIPCOM7

51 HACKAME6

1 AGOSGLA6

46 GAILARI6

62 LEPIDEN6

12 ARTEFRI6

17 BOUTGRA7

97 STIPSPA7

7 ANTEPAR6

73 POTEHIP6 -108

6 ANEMPAT6 -114

50 GEUMTRI6 -137

Test

SAMPLE SCORES - WHICH ARE WEIGHTED MEAN SPECIES SCORES - WHICH ARE WEIGH DD MEAN SPECIES SCORES

$\begin{array}{rlrrr}1 & \text { P01 } & 433 & 114 & 53 \\ 2 & \text { P02 } & 240 & 171 & 81 \\ 3 & \text { P03 } & 15 & 0 & 187 \\ 4 & \text { P04 } & 517 & 138 & 152 \\ 5 & \text { P05 } & 468 & 137 & 184 \\ 6 & \text { P06 } & 225 & 185 & 65 \\ 7 & \text { P07 } & 84 & 83 & 139 \\ 8 & \text { P08 } & 64 & 36 & 182 \\ 9 & \text { P09 } & 24 & 63 & 147 \\ 10 & \text { P10 } & 150 & 66 & 277 \\ 11 & \text { P11 } & 262 & 154 & 74 \\ 12 & \text { P12 } & 734 & 139 & 141 \\ 13 & \text { P13 } & 81 & 220 & 109 \\ 14 & \text { P14 } & 22 & 279 & 67 \\ 15 & \text { P15 } & 82 & 115 & 125 \\ 16 & \text { P16 } & 80 & 129 & 123 \\ 17 & \text { P17 } & 160 & 173 & 105 \\ 18 & \text { P18 } & 50 & 77 & 177 \\ 19 & \text { P19 } & 25 & 293 & 50 \\ 20 & \text { P20 } & 735 & 137 & 136 \\ 21 & \text { P21 } & 0 & 345 & 15 \\ 22 & \text { P22 } & 66 & 113 & 151 \\ 23 & \text { P23 } & 290 & 160 & 114 \\ 24 & \text { P24 } & 171 & 91 & 80 \\ 25 & \text { P25 } & 345 & 102 & 21 \\ 26 & \text { P26 } & 74 & 85 & 169 \\ 27 & \text { P27 } & 333 & 242 & 253 \\ 28 & \text { P28 } & 75 & 250 & 45 \\ 29 & \text { P29 } & 322 & 92 & 19 \\ 30 & \text { P30 } & 231 & 160 & 183\end{array}$
$\mathrm{EIG}=0.886$

20 P20

$12 \mathrm{P} 12$

39 P39

4 P04

5 P05

1 P01

25 P25

$\begin{array}{ll}27 & \text { P27 }\end{array}$

29 P29

36 P36

23 P23

11 P11

2 P02

30 P30

6 P06

$\begin{array}{ll}37 & \text { P37 }\end{array}$

35 P35

24 P24

34 P34

31 P31

$\begin{array}{ll}17 & \text { P17 }\end{array}$

10 P10

$38 \quad$ P38

$\begin{array}{ll}33 & \text { P33 }\end{array}$

32 P32

7 P07

15 P15

13 P13

16 P16

28 P28
RANKED 2

$\mathrm{EIG}=0.417$

21 P21

19 P19

14 P14

28 P2 8

$\begin{array}{ll}27 & \text { P27 }\end{array}$

34 P34

13 P13

35 P35

38 P38

6 P06

17 P17

2 P02

$\begin{array}{ll}37 & \text { P37 }\end{array}$

23 P23

30 P30

11 P11

39 P39

12 P12

4 P04

5 P05

20 P20

16 P16

32 P32

36 P36

15 P15

$1 \mathrm{P} 01$

22 P22

25 P2 5

29 P29

24 P24

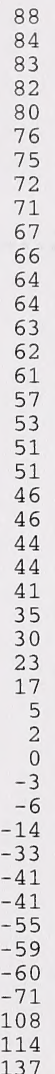




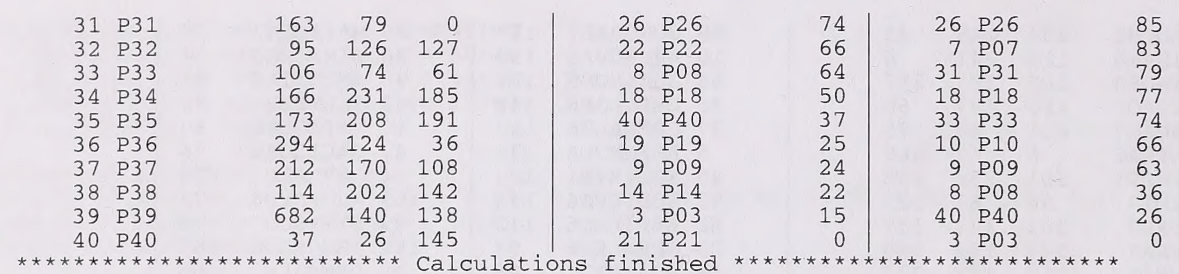



NATIONAL LIBRARY OF CANADA

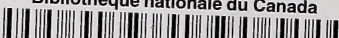

33286528653211 